Joyce Marques Barbosa

Microgramma squamulosa (Kaulf.) de la Sota e Pleopeltis hirsutissima (Raddi) de la Sota: estratégias contrastantes de uso da água em um ambiente epifítico 
Joyce Marques Barbosa

\section{Microgramma squamulosa (Kaulf.) de la Sota e Pleopeltis hirsutissima (Raddi) de la Sota: estratégias contrastantes de uso da água em um ambiente epifítico}

Dissertação apresentada ao Instituto de Biociências da Universidade de São Paulo para a obtenção do Título de Mestre em Ciências, na Área de Ecologia

Orientador: Prof. Dr. Sergio Tadeu Meirelles

Versão corrigida após a defesa. A versão original desta dissertação encontra-se disponível no Instituto de Biociências da USP. 
Ficha Catalográfica

Barbosa, Joyce Marques

Microgramma squamulosa (Kaulf.)de la Sota e Pleopeltis hirsutissima (Raddi) de la Sota : estratégias contrastantes de uso da água em um ambiente epifítico / Joyce Marques Barbosa ; orientador Sergio Tadeu Meirelles. --. São Paulo, 2012.

$108 \mathrm{f}$.

Dissertação (Mestrado) - Instituto de Biociências da Universidade de São Paulo. Departamento de Ecologia.

1. Tolerância à Dessecação. 2. Estresse Hídrico. 3. Epífitas

4. Fluorescência da clorofila. I. Universidade de São Paulo.

Instituto de Biociências. Departamento de Botânica. II. Título.

Comissão Julgadora:

Prof.(a) Dr.(a)

Prof.(a) Dr.(a)

Prof. Dr. Sergio Tadeu Meirelles

Orientador 
Dedico este trabalho aos meus pais: Cleusa Marques Barbosa e João Batista de Camargo Barbosa Neto, por me presentearem com o mais valioso dos tesouros, a vida. 


\section{Agradecimentos}

Ao Prof. Dr. Sergio Tadeu Meirelles, pela paciência e orientação tanto relacionada a assuntos acadêmicos quanto aqueles ligados a vida cotidiana.

À CAPES, pela bolsa concedida

Aos colegas de laboratório: Bira, Davi, Cristiano, Olidan e Renata, que sutilmente se tornaram amigos. Compartilhando momentos bons a momentos difíceis e partilhando desde técnicas de extração de clorofila até técnicas avançadas de jutsus.

Aos alunos de iniciação e pré-iniciação: Juliano, Fernando e Bianca pelo apoio e por tornarem os dias mais alegres.

Ao técnico de laboratório Mauricio Perine, por todo apoio e constante disposição para nos auxiliar.

À Profa. Dra. Regina Moraes, por facilitar imensamente o trabalho de extração de clorofila com o DMSO e por todo o carinho.

À Vera Lima, por toda atenção e auxílio prestado.

Ao Luis Carlos de Souza, por divertir os inúmeros dias que passei em frente ao pc na sala da pós e por todo auxílio prestado, resolvendo inclusive o enigma do "realce fantasma".

À todos os funcionários do IB, pelo convívio e apoio diário.

À minha base, minha família: meus pais (João e Cleusa), meus tios (Reilo e Maria Cecilia), meus cachorros (Puppy, Luna e Pliclous) e em especial a minha irmãzinha (Giselle) por me auxiliar em campo. Sem vocês eu nada seria.

À todos meus amigos, por darem sentido maior à vida. Em especial minhas amigas/irmãs: Antonia e Katherine, por auxiliarem de forma efetiva neste trabalho e sempre acreditarem em mim, muitas vezes, mais do que eu mesma.

Às espécies Microgramma squamulosa e Pleopeltis hirsutissima, que permitiram a existência desse trabalho. Que este possa compensar o custo de suas folhas. 
"A verdadeira viagem de descobrimento não consiste em procurar novas paisagens, mas em ter novos olhos" 


\section{RESUMO}

Entre os vegetais existem duas estratégias distintas para superar as condições de estresse hídrico que condicionam a sensibilidade a dessecação (SD) que está associada a mecanismos de evitação e a tolerância a dessecação (TD) que envolve suportar o estresse hídrico diretamente no nível dos tecidos e no nível subcelular. Sabe-se que os custos acoplados aos mecanismos de dessecação e reidratação em espécies TD são elevados, e provavelmente superiores aos de espécies SD. Desta forma, a coexistência de espécies com estas estratégias, como ocorre no ambiente epifítico da Cidade Universitária Armando Sales de Oliveira (CUASO), induzem questões quanto a as vantagens relativas de espécies TD sobre SD. Devido aos altos custos da estratégia TD é possível propor que estas deveriam apresentar um ganho médio de carbono superior a de espécies SD durante o período favorável (com disponibilidade hídrica). Além disso, também é razoável esperar que as distintas formas de uso da água, vinculadas às estratégias, poderiam facilitar o convívio de espécies TD e SD através da segregação de nichos. Com intuito de verificar essas hipóteses, foram realizadas análises relacionadas a estrutura de comunidade de epífitas da CUASO e, a partir destas, a detecção da associação espacial mais freqüente, que resultou composta por Pleopeltis hirsutissima (TD) e Microgramma squamulosa (SD). Estas espécies foram então selecionadas para avaliar parâmetros associados à dinâmica do uso da água, assimilação líquida de carbono, dinâmica da capacidade de uso da luz, estado de hidratação foliar e pigmentos fotossintéticos. Os resultados apontaram que espécies de ambas as estratégias não apresentam sinais de estresse crônico no ambiente estudado. Os dados reforçaram as respostas contrastantes de TD e SD, refletindo as formas distintas de lidar com os recursos e condições do ambiente. Ao contrário do esperado, P.hirsutissima não apresentou uma assimilação de carbono superior a M.squamulosa, indicando que o ganho de carbono não é um dos fatores possíveis na compensação dos custos acoplados a sua estratégia (TD). Porém, os resultados apresentados quanto a dinâmica da capacidade de uso da luz sugerem que a coexistência é facilitada pela segregação de nichos de luz, sendo a espécie TD mais heliófila do que a espécie SD.

Palavras-chave: Tolerância à dessecação; Estresse hídrico; Epífitas; Fluorescência da clorofila; Fotossíntese 


\begin{abstract}
In land plants the resistance to drought can be accomplished by two main strategies. One involves mainly dehydration avoidance mechanisms and the other is based on the ability to withstand drought at the tissues and down to subcellular levels. The former is found on the desiccation sensitive plants (DS) and the last describes the desiccation tolerant plants (DT). The metabolic costs of the desiccation tolerance mechanisms are probably high, at least when considering the cessation of photosynthesis during anabiosis - a condition that is absent in drought avoidance strategies. The coexistence of drought avoiders and desiccation tolerant plants in the same substrate and condition can rise some questions about the relative advantages of each strategy when submitted to similar water regime. We ask whether desiccation tolerant plants have a compensatory carbon gain under a watering regime that induces frequent anabiosis or cumulative damage in drought avoidance have a detrimental effect comparable to the costs of the desiccation tolerance. An analysis of the epiphytic plant community associated to the trees of the CUASO urban landscape showed a very frequent co-occurring species pair including the desiccation sensitive Microgramma squamulosa and a desiccation tolerant Pleopeltis hirsutissima, both cryptogams of the same plant family. These species were thoroughly examined regarding the patterns of light, water and carbon dynamics together with pigments concentration during cycles of natural drought and wet climate field conditions. These observations were complemented with experimental induction of different water and light regimes. The results showed no sign of chronic stress in both plants living at the same condition but allowed us to identify large distinctions in resource use patterns. A compensatory carbon assimilation was not found in P.hirsutissima. Both species have similar $\mathrm{CO} 2$ assimilation values. Experimental induction of drought in different light regimes allowed to verify a relative advantage in desiccation tolerant Phirsutissima in comparison to the desiccation sensitive Msquamulosa under high irradiance values. Furthermore, light curve analysis suggest that they share the same tree but their niches differ in light intensity regime allowing the high frequency of co-occurrence observed in the field.
\end{abstract}

Keywords: Desiccation tolerance; Drought stress; Epiphytes; Chlorophyll fluorescence; Photosynthesis 


\section{LISTA DE SÍMBOLOS E SIGLAS}

CUASO Cidade Universitária Armando de Salles Oliveira

SD Sensível à dessecação

TD Tolerância à dessecação

A Assimilação de carbono $\left(\mu \mathrm{mol} \mathrm{m} \mathrm{m}^{-2} \mathrm{~s}^{-2}\right)$

EUA Eficiência no uso da água $\left(\mu \mathrm{mol} \mathrm{mmol}^{-1}\right)$

Fv/Fm Rendimento quântico máximo aparente do fotossistema II

Fv Fluorescência variável $(F v=F m-F o)$

Fm Fluorescência máxima

Fo Fluorescência basal

Fv'/Fm' Rendimento quântico efetivo do fotossistema II

CRA Conteúdo relativo de água (\%)

ETR Taxa de transferência de elétrons $\left(\mu\right.$ mols $\left.\mathrm{m}^{-2} \mathrm{~s}^{-1}\right)$

PSII Fotossistema II

P.C.L Ponto de compensação luminosa ( $\mu \mathrm{mol} \mathrm{m}-2 \mathrm{~s}-1)$

R.Q.A Rendimento quântico aparente ( $\mu \mathrm{mol} \mathrm{m}-2 \mathrm{~s}-1)$ 


\section{Sumário}

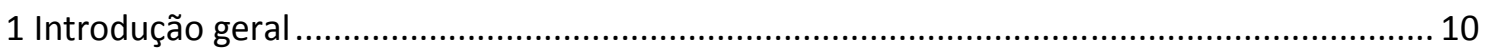

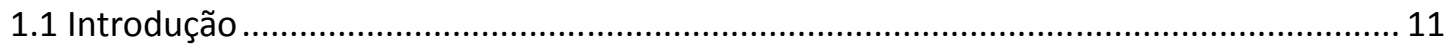

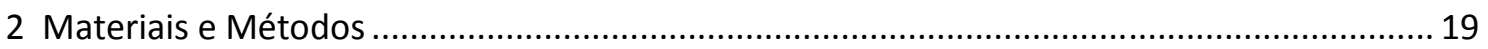

2.1 Análise da estrutura da comunidade de epífitas ......................................................... 19

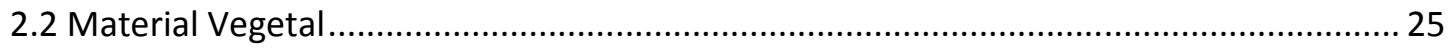

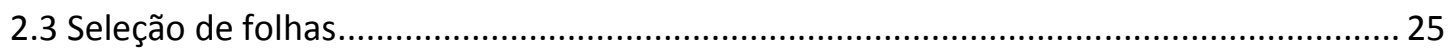

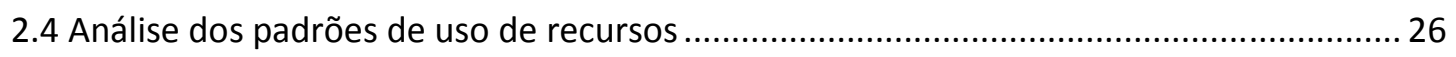

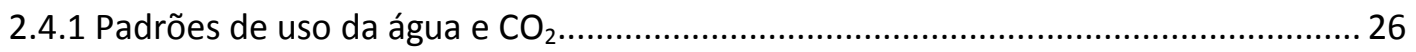

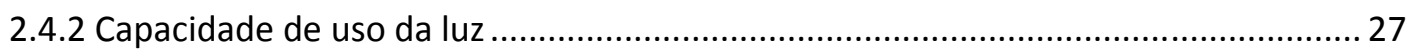

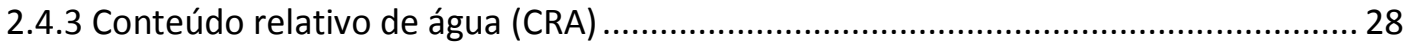

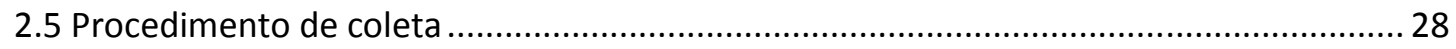

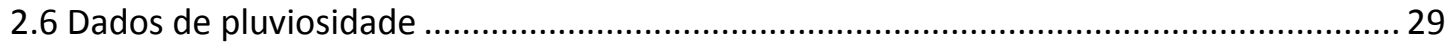

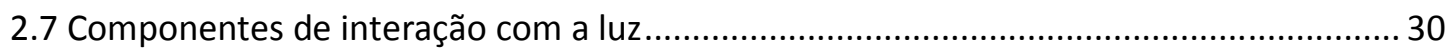

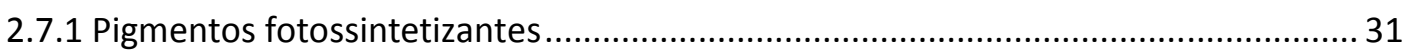

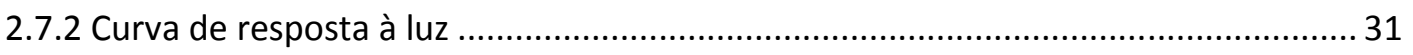

2.7.3 Efeitos da interação entre luz e suspensão da provisão hídrica ................................ 32

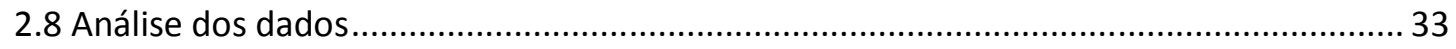

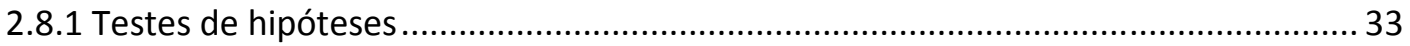

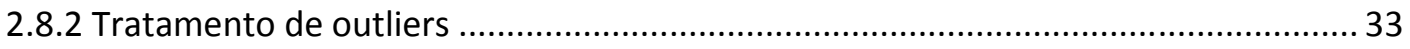

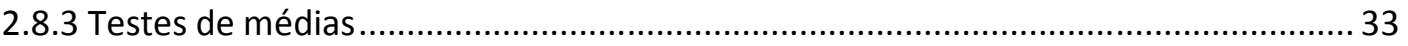

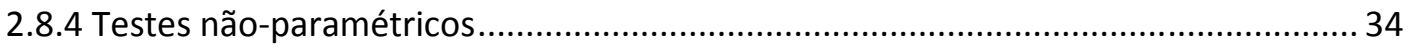

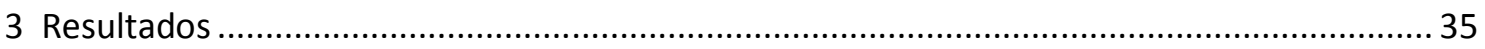

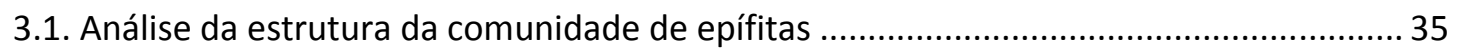

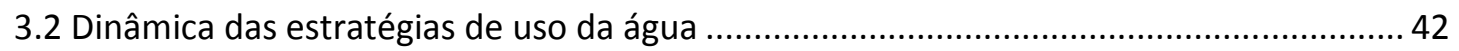

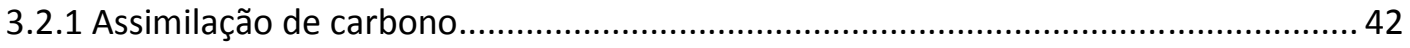

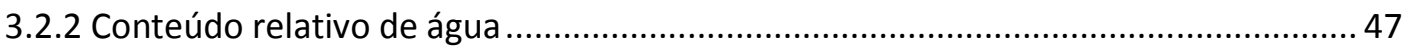


3.2.3 Rendimento quântico máximo aparente do PSII

3.2.4 Rendimento quântico efetivo do PSII......................................................... 56

3.2.5 Taxa de transferência de elétrons......................................................... 57

3.2.6 Eficiência do uso da água ..................................................................... 58

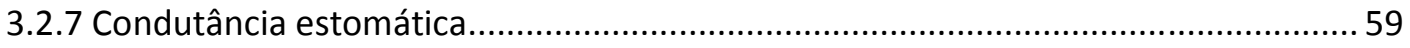

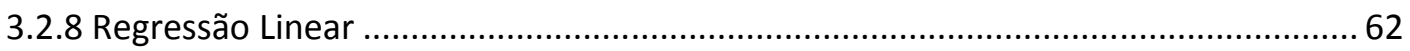

3.3 Componentes de interação com a luz ............................................................... 66

3.3.1 Pigmentos fotossintetizantes ................................................................. 66

3.3.2 Efeitos da interação entre luz e suspensão da provisão hídrica ............................. 69

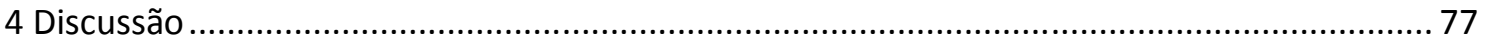

4.1 Estrutura da comunidade ............................................................................ 77

4.2 Ecofisiologia de Microgramma squamulosa ...................................................... 79

4.3 Ecofisiologia de Pleopeltis hirsutissima ............................................................ 80

4.4 Ecofisiologia comparativa ........................................................................... 83

4.4.3 Segregação de nichos .............................................................................. 85

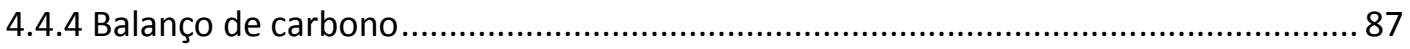

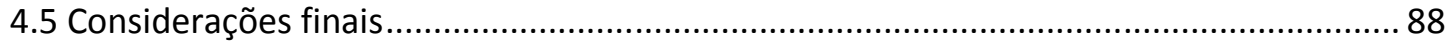

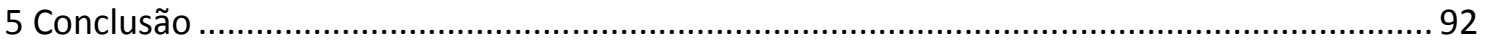

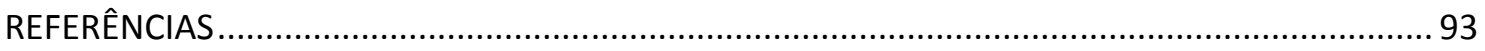

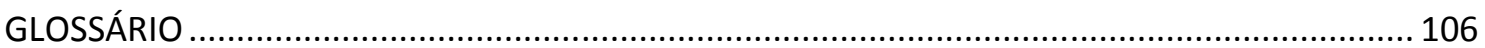




\section{Introdução geral}

Nem todas as espécies que alcançam um determinado ambiente são capazes de ocupá-lo (KEDDY, 1992; GRIME, 2006). A ocupação de um ambiente e, por consequência, sua composição de espécies é determinada por processos de interação entre as espécies com o ambiente e das interações das espécies entre si (CORNWELL, SCHWILK; ACKRELY, 2006).

A interação das espécies com o ambiente é o primeiro fator decisivo na composição de espécies (WEIHER; KEDDY, 1995). As condições físicas e os recursos presentes no ambiente funcionam como filtros fisiológicos que permitem ou impedem a estabilização de espécies potencialmente colonizadoras dependendo de suas limitações fisiológicas (LAMBERS; CHAPIN; PONS, et al., 2008; VENN et al., 2011).

Após superarem o filtro fisiológico, o estabelecimento e manutenção das espécies são determinados pelas interações entre as espécies (filtro biótico), uma vez que as espécies irão competir pelos recursos presentes (LAMBERS; CHAPIN; PONS, et al., 2008, p.3). Para permitir a coexistência, os animais podem repartir os recursos ou utilizar recursos distintos, diferenciando seus nichos para garantir a manutenção de seus genes (BEGON; TOWSEND; HARPER, 2006, p.258). Porém, para as plantas cujos recursos fundamentais são comuns: luz, água e nutrientes (SILVERTON, 2004), a facilitação da competição pode ser realizada através da separação espacial ou temporal dos recursos, ou ainda pela habilidade das espécies utilizarem os recursos (BEGON; TOWSEND; HARPER, 2006, p.259).

Possuir uma estratégia bem sucedida, que supere os filtros ambientais e garanta o estabelecimento em determinado ambiente torna a ocupação de outro tipo de ambiente difícil ou impossível para a mesma espécie (KREBS, 1994). Por exemplo, o investimento de recursos em uma maior área foliar, com intuito de gerar folhas eficientes para captar a radiação solar, impede o investimento na formação de folhas mais densas, que apresentem maior longevidade (CRAINE, 2005). Desta forma, o bom desempenho de uma função implica no prejuízo de outra função (KNEITEL; CHASE, 2004), o que impede que uma única espécie seja capaz de colonizar todos os tipos de ambientes. Essa teoria é mais conhecida pelos ecólogos como trade-offs ou demandas conflitantes. 
Acredita-se que quanto mais restritivo é um ambiente, maior é a dificuldade de uma espécie superar 0 seu filtro ambiental e, consequentemente, uma diversidade menor de tipos de estratégias consegue se estabelecer (DÍAZ; CABIDO 2001). Dessa forma, o filtro ambiental pode ser entendido como um redutor do número de estratégias de sucesso que irão se estabelecer e coexistir em um determinado ambiente (CORNWELL; SCHWILK; ACKRELY, 2006).

Ambientes secos ou que apresentam imprevisibilidade quanto à disponibilidade hídrica, são exemplos de ambientes com um filtro ambiental restritivo. Para a maior parte das espécies a remoção da água no nível de $20 \%$ causa agregação irreversível de macromoléculas, de membranas e desintegra organelas (ALPERT, 2006). Logo, a perda de água pode ser considerada um dos primeiros obstáculos a serem superados para se obter sucesso no ambiente terrestre.

\subsection{Introdução}

Entre os vegetais são conhecidas duas estratégias para superar condições de baixa disponibilidade hídrica e se estabelecer: 1) Não permitir a dessecação dos tecidos; e 2) Permitir a dessecação sem que ocorram danos irreversíveis (ALPERT; OLIVER, 2002, p.4). Segundo o conceito proposto por Levitt (1980, p.355), essas estratégias de resistir à seca correspondem à divisão entre: evitação à seca e a tolerância à seca, que condicionam as plantas a sensibilidade à dessecação e a tolerância à dessecação, respectivamente.

As espécies sensíveis à dessecação (SD) possuem características adaptativas como a presença de cutícula espessa, pequena superfície, suculência, tecido armazenador de água, controle estomático, fechamento estomática durante o período diurno, presença de tricomas e alta refletância (LEVITT, 1980, p.382). Essas características permitem com que as plantas mantenham um conteúdo de água favorável nos tecidos, através do aprimoramento da absorção da água, capacidade de condução da água, redução da perda de água e o armazenamento da água (LARCHER, 2003, p.266). 
Em contraste às espécies SD, as plantas tolerantes à dessecação (TD) (BEWLEY, 1979), também conhecidas como revivescentes (GAFF, 1971), possuem a capacidade de sobreviver em equilíbrio dinâmico dos tecidos com o ar em baixa umidade relativa (LEVITT, 1980, p.387). Os organismos TD suportam a dessecação completa, sobrevivendo com um conteúdo interno de água igual ou menor do que 10\% (ALPERT, 2005, 2006).

Quando atingem o nível de dessecação completa, os organismos TD entram em um estado denominado de anabiose ou anidrobiose (CROWE; HOESKSTRA; CROWE, 1992) no qual ocorre a cessação das atividades metabólicas em níveis mensuráveis (ROTHSCHILD; MANCINELLI, 2001). Em condições favoráveis, os organismos podem permanecer nesse estado durante décadas ou talvez séculos até a água ser novamente disponibilizada (CROWE; HOESKSTRA; CROWE, 1992) e permitir a retomada de seu estado funcional (LEVITT, 1980, p.387).

Por apresentarem respostas distintas durante 0 processo de dessecação, a estratégia TD é dividida entre dois tipos: 1) TD constitutiva ou verdadeira e 2) TD indutiva ou modificada. Plantas TD constitutivas mantêm constantemente processos e componentes necessários para proteger as células dos possíveis danos da dessecação. De forma contrária, em plantas TD indutivas os processos e componentes necessários são induzidos somente quando as condições de seca se tornam presentes (OLIVER; BEWLEY, 1997; OLIVER; TUBA; MISHLER, 2000).

Apesar de espécies TD e SD apresentarem estratégias contrastantes, as respostas apresentadas por TD indutivas e SD se sobrepõem de níveis leves a moderados de deficit hídrico (NEALE et al., 2000). Para possibilitar de forma temporal a indução dos mecanismos de proteção e reparo, as espécies TD indutivas resistem à perda de água nas fases iniciais de deficit hídrico (OLIVER; WOOD; O'MAHONY, 1998; NEALE et al., 2000). Esse comportamento foi verificado em diversas espécies, como Xerophyta plicata Spreng (Nanuza plicata (Mart.) L.B. Sm. \& Ayensu:) (MEGURO; JOLY; BITTENCOURT, 1977), Xerophyta humilis (Bak.) Dur. and Schinz, Craterostigma wilmsii (Farrant et al., 1999), Eragrostis nindensis Fic. and Hiern (WILLIGEN et al., 2001, e Pleurostima purpurea (Hook.) Raf (AIDAR et al., 2010). 
Entre as angiospermas, a estratégia TD é dividida também quanto a proteção contra os danos oxidativos, podendo controlá-los de duas formas: (1) através do desmantelando dos tilacóides e da degradação da clorofila; ou, (2) através do enrolamento das folhas e síntese de antocianinas, quando a clorofila e a membrana são mantidas (INGLE et al., 2007; TOLDI; TUBA; SCOOT, 2009; LEPRINCE; BUITINK, 2010). Essas formas dizem respeito a estratégias conhecidas como: (1) peciloclorofillia e (2) homeoclorofillia (TOLDI; TUBA; SCOOT, 2009). As espécies peciloclorófilas desmancham o aparato fotossintético, perdem totalmente a clorofila durante a dessecação e a ressintetizam durante a reidratação (TUBA; PROCTOR; CSINTALAN, 1998). Em contraste, espécies homeoclorófilas não sobrevivem a uma perda de clorofila que exceda o montante crítico fisiológico (TOLDI; TUBA; SCOOT, 2009), a retendo durante todo período de anabiose (TUBA; PROCTOR; CSINTALAN, 1998).

As estratégias de peciloclorofilia e homeoclorofilia parecem estar ligadas a um trade-off entre o custo de proteção e reparo do aparato fotossintético (ROTHSCHILD; MANCINELLI, 2001). Espécies peciloclorófilas sofrem menos danos foto-oxidativos durante o período seco, mas necessitam investir para reconstruir o seu aparato fotossintético. Por sua vez, espécies homeoclorófilas possuem uma recuperação mais rápida após a reidratação, porém apresentam maiores custos energéticos para o reparo celular (TUBA, 2008).

Apesar de ser possível encontrar plantas peciloclorófilas e homeoclorófilas em um mesmo ambiente, cada uma apresenta melhor eficiência em ambientes distintos. A estratégia de peciloclorofilia ocorre mais em ambientes que apresentam períodos de seca prolongados, tornando o desmanche do aparelho fotossintético mais vantajoso do que sua manutenção. De forma contrária, espécies homeoclorófilas são geralmente encontradas em ambientes que possuem períodos menores entre a seca e as chuvas (como ocorre na CUASO), permitindo uma recuperação mais rápida (INGRAM; BARTELS, 1996, SHERWIN; FARRANT, 1996, TUBA et al., 1996, GEORGIEVA et al., 2007).

Evidências na evolução do genoma indicam que a capacidade de sobreviver à dessecação dos tecidos estava entre as primeiras modificações facilitadoras para a conquista do ambiente terrestre (RESING et al., 2008), e que a TD foi apresentada de forma primitiva em briófitas (OLIVER; TUBA; 
MISHLER, 2000). A despeito do sucesso da estratégia TD para o estabelecimento das plantas no ambiente terrestre, a evolução seguiu de forma a selecionar indivíduos que apresentavam uma complexidade morfológica e mecanismos que permitiam evitar à dessecação (FERNÁNDES-MARín et al., 2011). Desta forma, a grande maioria das plantas atuais é sensível à dessecação (SD), sendo capazes de sobreviver somente a um déficit hídrico moderado e suportar geralmente um conteúdo relativo de água de até $80 \%$ durante curtos períodos de tempo (ILJIN, 1957).

Apesar da estratégia SD tenha se tornado mais comum entre as plantas, a estratégia TD continua sendo encontrada em espécies avasculares e, embora seja mais raro, também são encontradas em espécies vasculares (ocorrendo em apenas 0,02 \%) (POREMBSKI; BARTHLOTT, 2000). A TD apresenta uma distribuição ampla, mas desigual entre os táxons, sendo comum em briófitas, rara em pteridófitas e angiospermas (monocotiledôneas e eudicotiledôneas), e inexistente em gimnospermas (ALPERT, 2000).

A maior parte das espécies avasculares apresenta o tipo constitutivo da TD, com exceção de algumas espécies de briófitas, e as espécies vasculares apresentam o tipo indutivo (OLIVER, 1996). Existe entre 25000 a 30000 espécies de briófitas capazes de tolerar a dessecação. São estimadas entre 275 a 325 espécies vasculares TD, divididas em pelo menos nove famílias de pteridófitas e sete famílias de angiospermas com esporófitos TD e alguns gametófitos (ALPERT; OLIVER, 2002, p. 10).

Considera-se que a ocorrência de TD em táxons de plantas vasculares é decorrente de pressões seletivas em ambientes secos (OLIVER; TUBA; MISHLER; MISHLER, 2000; OLIVER; VELTEN; MISHLER, 2005). A existência de sistemas que conferem tolerância à dessecação em tecidos vegetativos de plantas vasculares seria possível dado que genes associados à capacidade de tolerar a dessecação já existem durante o processo de maturação de sementes (sementes ortodoxas) e esporos. Isto leva a crer que o potencial genético de TD está presente na grande maioria das plantas (ALPERT; OLIVER, 2002). Essa suposição vai ao encontro da hipótese de Illing et al. (2005) de que a TD no tecido vegetal é uma consequência da ativação de genes específicos de sementes em resposta a sinais ambientais específicos. 
É provável que o favorecimento evolutivo de espécies SD tenha sido devido aos custos menos elevados associados a sua estratégia do que quando comparado a estratégia TD (OLIVER; TUBA; MISHLER, 2000). Além da cessação da assimilação de carbono decorrente do estado de anabiose, espécies TD apresentariam altos custos associados à proteção e reparos necessários para viabilizar a sua estratégia. Para sobreviverem à dessecação completa, plantas TD devem ser capazes de: a) limitar os danos durante a dessecação; b) quando no estado dessecado, manter a integridade fisiológica até um nível reparável; e c) mobilizar mecanismos para que os danos sofridos durante a dessecação e sejam reparados durante a reidratação (BEWLEY, 1979).

Para sobreviverem a dessecação, as espécies TD apresentam mecanismos relacionados a estabilização e preservação dos componentes celulares (HOEKSTRA; GOLOVINA; BUITINK, 2001; COLVILLE; KRANNER, 2010) através do acúmulo de açucares como a sacarose (WHITTAKER et al., 2001), trealose (MOORE et al., 2007) e oligossacarídeos de cadeia curta (PETERS et al., 2007). Possuem também proteinas relacionadas, como a proteína "late embryogenesis abundant" (LEA) que suporta o papel dos açúcares (INGRAM; BARTELS, 1996), impedindo a fusão das membranas, atuando como protetores de macromoléculas, (GARRAY-ARROYO et al., 2000; HOESKA; GOLOVINA; BUITINK, 2001), protetores do DNA, estabilizadores de filamentos do citoesqueleto (WISE; TUNNACLIFFE, 2004), ou como as proteínas de choque térmico (heat shock proteins) (PRITEO-DAPENA et al., 2008) e os polifenóis (MOORE et al., 2005), que possuem papéis similares aos das proteínas Lea, protegendo a membrana contra os danos da dessecação.

A viabilidade de plantas TD depende também de mecanismos de proteção contra a luz eficientes. Apresentam sistemas antioxidantes de proteção e reparo de danos que incluem: a) mecanismos de defesa enzimáticos: o ascorbato peroxidase, glutationa peroxidase, tiorredoxina, catalase, glutationa redutase, e superóxido dismutase, e b) mecanismos de defesa não enzimáticos: glutationa; ascorbato; e tocoferol (JAMIESON, 1998; MITTLER, 2002; ILLING et al., 2005).

Apesar de serem amplamente distribuídas geograficamente, ocorrendo em todos os continentes, as plantas TD apresentam um alcance ecológico 
limitado, especialmente as vasculares (ALPERT, 2000). Mais de $90 \%$ das plantas TD vasculares vivem sobre afloramentos rochosos, tornando-os um centro de diversidade e convergência de formas de vida de espécies TD de vários clados (ALPERT, 2000; POREMBSKI; BARTHLOTT, 2000).

Plantas TD parecem apresentar vantagens em ambientes com regimes hídricos imprevisíveis em termos da frequência com que a água é disponibilizada no ambiente (ALPERT; OECHEL, 1985) e do tipo de substrato em que as plantas estão acopladas, uma vez que substratos de drenagem rápida ou substratos que não permitem o acúmulo de água garantem a imprevisibilidade de sua disponibilidade hídrica (MEIRELLES, 1997). Além desses fatores, espécies TD também são limitadas a áreas em que espécies sensíveis à dessecação são escassas (ALPERT, 2000).

Duas hipóteses têm sido propostas para explicar a raridade de plantas TD: 1) Hipótese de balanço de carbono e 2) Hipótese de demanda conflitante com a produtividade (ALPERT, 2000). A hipótese de balanço de carbono defende que os ciclos repetidos de dessecação e reidratação, que ocorrem em ambientes com períodos curtos entre as chuvas, levam ao acúmulo de perda de carbono que inviabiliza a estratégia (ALPERT; OECHEL, 1985; LANGE et al.,1994; ALPERT, 2000).

Por sua vez, a hipótese de demanda conflitante com a produtividade defende que os custos associados com a habilidade de tolerar a dessecação contrariam a produtividade (OLIVER; TUBA; MISHLER, 2000). A crescente compreensão dos mecanismos de TD sugere que esta estratégia e a produtividade podem apresentar dois tipos comuns de demandas conflitantes: evitar a mortalidade em conflito com a aquisição de recursos, e alocação de recursos em conflito as funções concorrentes (ALPERT, 2006). Essa segunda hipótese permite propor ainda que a baixa produtividade levaria a baixa competitividade de espécies TD, causando a exclusão de espécies TD em ambientes em que espécies SD estão presentes (ALPERT, 2000).

As espécies epifíticas TD e SD presente no ambiente epifítico da arborização paisagística da Universidade de São Paulo parecem contrariar os fatores apresentados por ambas às hipóteses propostas anteriormente. As epífitas dependem diretamente da umidade atmosférica e da precipitação interna da copa escorrendo pelo tronco ou por gotejamento das folhas (ZOTZ; 
HIETS, 2001). A ausência ou pequeno volume de solo disponível no ambiente epifítico impede o armazenamento de água e torna sua escassez o principal fator limitante para o estabelecimento de espécies. Nessa condição, a completa ausência de água nos intervalos entre as chuvas torna o ambiente epifítico um ambiente extremo quanto à disponibilidade hídrica (KLUGE; AVADHANI; GOH, 1989 , p.87). Porém, o regime de chuvas da região estudada possui potencial para expor as espécies TD a constantes ciclos de dessecação.

Durante o período úmido, em que os espaços entre as chuvas são curtos, são observadas pteridófitas epifíticas com folhas contraídas e enroladas, sugerindo haver ciclos de desidratação e reidratação. A presença de espécies TD nessas condições parece contradizer a hipótese de balanço de carbono. Além disso, é possível observar com grande frequência o convívio de espécies TD e SD lado a lado, em um mesmo forófito (observação pessoal) fato que gera contradição com a hipótese da baixa competitividade de espécies TD devido à demanda conflitante com a produtividade. Logo, a presença de espécies TD em ambientes com curtos períodos entre as chuvas e, ao mesmo tempo, coexistindo ao lado de espécies SD nos permite sugerir que o sentido ecológico do padrão de uso da água associado com a tolerância à dessecação necessita ser melhor explorado.

Tomando como verdadeiro que os custos acoplados a estratégia TD são mais elevados do que os custos acoplados a estratégia SD, e que a manutenção de indivíduos de ambas as estratégias no forófito dependem de um balanço positivo de carbono, podemos levantar a seguinte questão:

Espécies epifíticas TD e SD que coexistem em um mesmo forófito, podem ser diferenciadas pelo ganho instantâneo de carbono?

É esperado que o ganho instantâneo de carbono de espécies tolerantes à dessecação, durante os períodos sem estresse hídrico, seja superior à assimilação de espécies sensíveis à dessecação (que não possuem gastos relacionados aos ciclos de dessecação e reidratação). Desta forma, os altos custos relacionados a estratégias TD seriam compensados pela alta eficiência durante os períodos favoráveis, 
resultando em uma compensação dos períodos nos quais a assimilação cessa devido à anabiose.

Por outro lado, é conhecido que o ambiente epifítico apresenta uma grande variação de quantidade de água armazenada no substrato e exposição luminosa (HIETZ; BRIONES, 2001), formando microhabitats e submetendo as espécies presentes a condições distintas dependendo da região do forófito ocupada. Dessa forma, outra questão pode ser levantada:

A coexistência de espécies TD e SD é facilitada pela segregação de nichos?

As epífitas ocupam regiões dos forófitos com exposições distintas de luminosidade, variando de regiões totalmente sombreadas a regiões totalmente expostas a luz (KLUGE; AVADHANI; GOH, 1989, p.97; LUTTGE, 1997, p.188.). Somando esse fato a maior eficiência de proteção contra a fotoinibição e danos foto-oxidativos apresentada pelas espécies TD, é possível levantar a hipótese de que espécies TD e SD apresentem segregação de nichos de intensidade luminosa, sendo que espécies TD ocupariam regiões do forófito mais expostas do que espécies SD. 


\section{Materiais e Métodos}

A presente seção foi dividida em três partes:

1) Estrutura da comunidade - com objetivo de conhecer a composição de espécies epifíticas da arborização paisagística da Universidade de São Paulo e selecionar a espécie SD e TD mais apropriadas para o estudo (2.1).

2) Padrões de uso de recursos - com objetivo de comparar o padrão de uso de recursos das espécies SD e TD e responder a primeira questão levantada (2.2 - 2.6).

3) Componentes de interação com a luz- com objetivo de verificar as respostas de espécies SD e TD em relação a luz e responder a segunda questão levantada (2.7).

\subsection{Análise da estrutura da comunidade de epífitas}

A comunidade de epífitas associadas à arborização do campus da Cidade Universitária Armando de Salles Oliveira (CUASO), localizada na Zona Oeste da cidade de São Paulo, bairro do Butantã, foi investigada com o objetivo de se determinar as espécies epifíticas de maior ocorrência, sua frequência, abundância absoluta e outras características da estrutura da comunidade que permitissem detectar padrões de ocorrência e possíveis associações nos forófitos.

Foram marcadas 1200 árvores com perímetro à altura do peito superior a $50 \mathrm{~cm}$, em sua grande maioria da espécie Tipuana tipu (Benth.) Kuntze, dispostas ao longo das vias da CUASO utilizando-se identificadores de plástico. As ruas e avenidas em que as árvores foram marcadas foram: Av. Professor Lineu Prestes, Av. Prof. Ernesto de M. Leme, Av. Prof. Almeida Prado, Av. Prof. Luciano Gualberto, Av. Prof. Lúcio M. Rodrigues, Av. Prof. Melo Morais, Rua do matão e Rua do lago. Das 1200 árvores marcadas, 114 foram sorteadas. Em cada árvore foram observadas as características de perímetro a altura do peito e as espécies de epífitas associadas.

As epífitas da família bromeliaceae foram classificadas apenas em tipos "tanque" (incluindo Vriesea sp., Aechmea sp. e Billbergia sp.) e "tillandsioide" (várias espécies de Tillandsia). As cactáceas foram consideradas apenas pelo gênero (Rhipsalis sp.) e as criptógamas vasculares foram identificadas pela espécie. Os tipos e as espécies consideradas estão listadas na Tabela 1. A 
presença de tolerância à dessecação foi inferida pela manifestação de um comportamento higroscópico nas folhas (folhas enroladas e com mudança de coloração durante períodos sem chuva), de forma semelhante ao descrito para a espécie Polypodium hirsutissimum Raddi (sinônimo de Pleopeltis hirsutissima Raddi) por Schmeing et al. (2007).

A partir dos dados coletados foi elaborada uma matriz binária contendo a ocorrência de cada espécie em cada forófito. Foram incluídas na análise apenas as espécies de epífita que ocorreram em mais de 2 forófitos. A matriz binária resultante continha 114 por 9 valores. Os padrões de ocorrência das espécies nos forófitos foram explorados através da mensuração da frequência de espécies epifíticas e de análises de ordenação, empregando a análise de correspondência (LEGENDRE; LEGENDRE, 1998). Os escores correspondentes aos forófitos, obtidos a partir da análise de correspondência foram utilizados para se testar o efeito do sítio de ocorrência e do perímetro à altura do peito empregando-se uma análise de variância. 
Tabela 1 - Espécies e tipos considerados para o levantamento epifítico da arborização do campus da Cidade Universitária Armando de Salles Oliveira (CUASO), seu hábito, estratégias de uso da água SD (sensíveis à dessecação) e TD (tolerantes à dessecação) e material-testemunha (voucher) coletado na reserva da CUASO.

\begin{tabular}{|c|c|c|c|c|}
\hline Espécie & Tipo & Hábito & Estratégia & $\begin{array}{c}\text { Material-testemunha } \\
\text { (DISLICH; MANTOVANI, 1998) }\end{array}$ \\
\hline $\begin{array}{l}\text { Microgramma squamulosa } \\
\text { (Kaulf.) de la Sota }\end{array}$ & - & Liana & SD & $\begin{array}{c}\text { Reserva da CUASO, 07.III,1994, R.Dislich } \\
\text { 60; 29.IV.1994, R.Dislich 76. }\end{array}$ \\
\hline $\begin{array}{l}\text { Microgramma vacciniifolia } \\
\text { (Langsd. \& Fisch.) Copel }\end{array}$ & 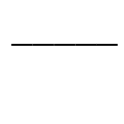 & Liana & SD & Reserva da CUASO, 21.V.1993, R. Dislich 9 \\
\hline $\begin{array}{l}\text { Pleopeltis astrolepis } \\
\text { (Liebmann) E. Fournier }\end{array}$ & & Liana cespitosa & TD & $\begin{array}{c}\text { Reserva da CUASO, 07.III.1994, R.Dislich } \\
\text { 60; 29. IV. 1994, R.Dislich } 76\end{array}$ \\
\hline $\begin{array}{l}\text { Pleopeltis hirsutissima } \\
\text { (Raddi) de la Sota }\end{array}$ & & Liana cespitosa & TD & $\begin{array}{c}\text { Reserva CUASO, 13.V.1993, R.Dislich 5, } \\
\text { R. Dislich 6; 21.V.1993, R.Dislich 7; } \\
\text { 03.V. 1994, R. Dislich } 88\end{array}$ \\
\hline $\begin{array}{l}\text { Pleopeltis pleopeltifolia } \\
\text { (Raddi) Alston }\end{array}$ & 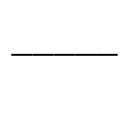 & Liana cespitosa & TD & Reserva CUASO, 23.VI.1993, R.Dislich 13. \\
\hline $\begin{array}{l}\text { Pleopeltis polypodioides } \\
\text { (Linnaeus) Watt }\end{array}$ & 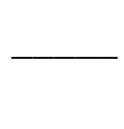 & Liana cespitosa & TD & \\
\hline
\end{tabular}




\begin{tabular}{|c|c|c|c|c|}
\hline Espécie & Tipo & Hábito & Estratégia & Material-testemunha \\
\hline $\begin{array}{l}\text { Serpocaulon catharinae } \\
\text { (Langsd. \& Fisch.) A.R. }\end{array}$ & - & Liana cespitosa & SD & $\begin{array}{c}\text { Reserva da CUASO, 13.V.1993, R.Dislich 2; } \\
\text { 14.III.1994, R. Dislich 66; 03.V.1994, }\end{array}$ \\
\hline $\mathrm{Sm}$ & & & & $\begin{array}{c}\text { R.Dislich 82; 02.IX.1994, R. Dislich 111; } \\
\text { 05.X.1994,R.Dislich 130; 30.1.1995, } \\
\text { R.Dislich 161 }\end{array}$ \\
\hline Tillandsia sp. & $\begin{array}{c}\text { Bromélia } \\
\text { atmosférica }\end{array}$ & Tillandsióide & SD & \\
\hline Aechmea sp. & $\begin{array}{l}\text { Bromélia } \\
\text { tanque }\end{array}$ & Bromélia tanque & SD & 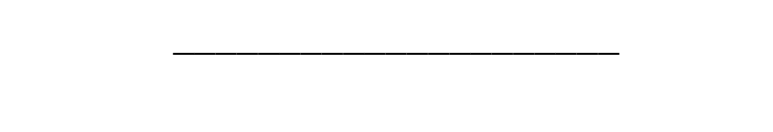 \\
\hline Billbergia sp. & $\begin{array}{l}\text { Bromélia } \\
\text { tanque }\end{array}$ & Bromélia tanque & SD & \\
\hline Vriesea sp. & $\begin{array}{l}\text { Bromélia } \\
\text { tanque }\end{array}$ & Bromélia tanque & SD & \\
\hline Rhipsalis sp. & - & Pendente & SD & \\
\hline Orchidaceae & - & Cespitosa & SD & \\
\hline
\end{tabular}


De forma complementar, foram executadas análises de agrupamento baseadas na matriz original e na matriz de escores resultantes da análise de correspondência. A análise de agrupamento baseada na matriz original foi desenvolvida a partir do coeficiente de similaridade de Jaccard calculado a partir da matriz binária. $O$ dendrograma de similaridade foi obtido através do algoritmo de média de grupo não ponderada. A distinção dos conjuntos de espécies com co-ocorrência aparente foi inferida através dos intervalos entre os enlaces ao longo do eixo de similaridade. A coerência entre os procedimentos de ordenação e classificação foi avaliada por uma análise de agrupamento utilizando-se os escores obtidos pelas epífitas nos 4 primeiros eixos resultantes da ordenação por análise de correspondência. Neste procedimento foi calculada uma matriz de distâncias de Mahalanobis a partir da qual foi aplicado o algoritmo de média de grupo.

Das 114 árvores selecionadas aleatoriamente, aquelas levantadas nas ruas e avenidas: Av. Professor Lineu Prestes, Av. Prof. Luciano Gualberto, Av. Prof. Lúcio M. Rodrigues, Av. Prof. Melo Morais, Rua do matão e Rua do lago, foram utilizadas para estimar a abundância absoluta de epífitas em casa árvore, totalizando 60 árvores (Figura 1). A estimativa de abundância foi realizada de março a junho de 2010. O procedimento consistiu em uma avaliação visual da cobertura que refletia a porcentagem de quanto cada espécie cobria a superfície do forófito (Braun -Blanquet, 1964 modificado). Para melhorar a estimativa, reduzindo a variação por visão do observador, essa análise foi realizada por três pessoas e o resultado final de cada forófito foi considerado a média dos valores obtidos. 


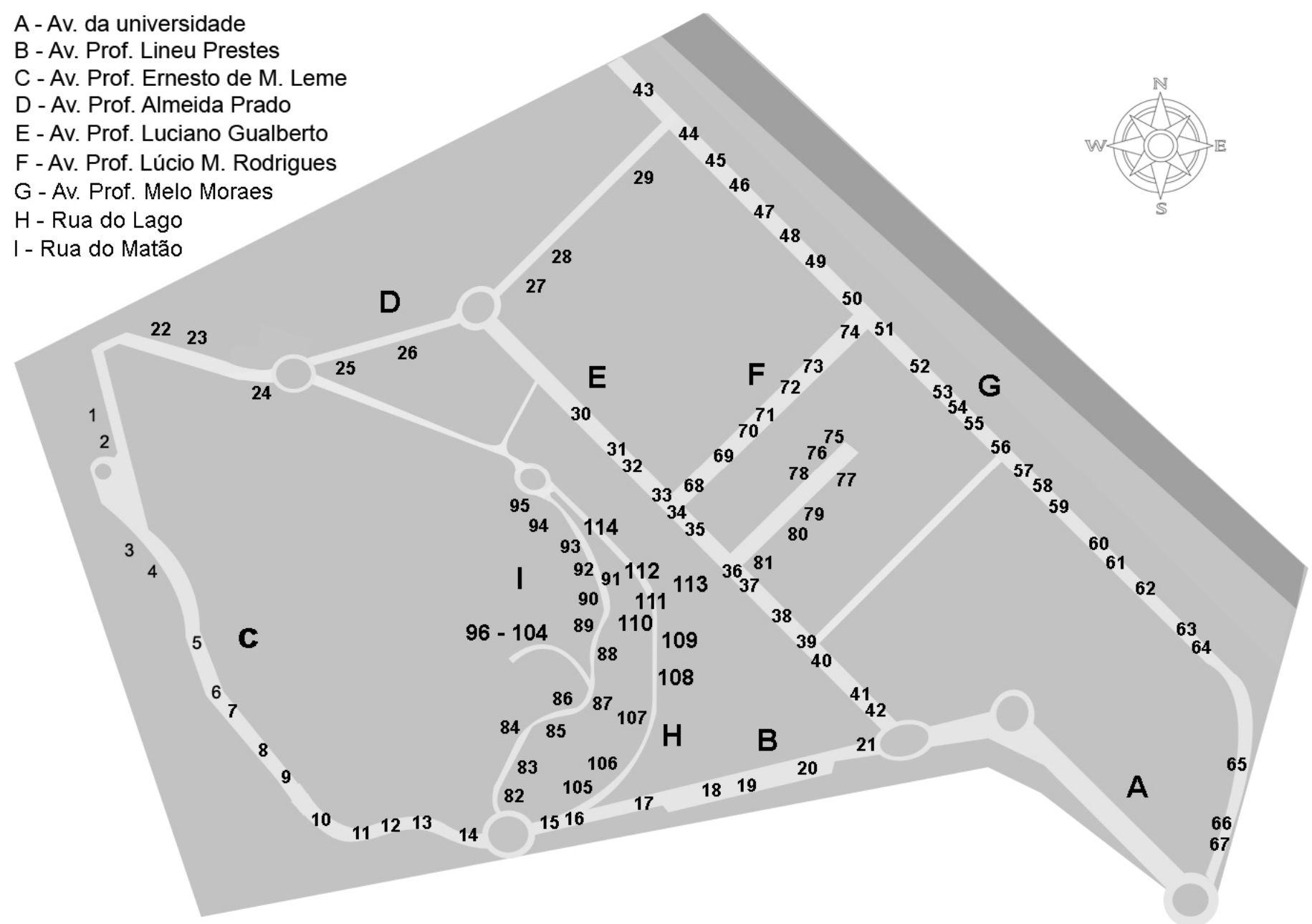

Figura 1 - Forófitos (representados pela numeração) selecionados para o levantamento da frequência de epífitas na Cidade Universitária Armando Sales de Oliveira (CUASO). As letras indicam os nomes das principais vias da CUASO. 


\subsection{Material Vegetal}

Com base nos resultados obtidos quanto a estrutura da comunidade, as espécies de pteridófitas epifíticas TD e SD selecionadas foram Pleopeltis hirsutissima (Raddi) de la Sota e Microgramma squamulosa (Kaulf.) de la Sota, respectivamente. Essas espécies foram selecionadas pelo fato de apresentarem os maiores valores de frequência e alta associação espacial na arborização paisagística do campus da Cidade Universitária Armando de Salles Oliveira (CUASO), localizada na Zona Oeste da cidade de São Paulo, bairro do Butantã. Ambas as espécies pertencem à família Polypodiaceae, uma das maiores famílias de criptógamas vasculares, constituída por aproximadamente 56 gêneros e 1.200 espécies (SMITH et al., 2006).

Pleopeltis hirsutissima é uma espécie nativa e não endêmica do Brasil, presente em domínios fitogeográficos de Cerrado e Mata Atlântica. No Brasil essa espécie possui uma ampla distribuição ocorrendo no Centro-Oeste (Mato Grosso, Goiás, Distrito Federal, Mato Grosso do Sul), Sudeste (Minas Gerais, Espírito Santo, São Paulo, Rio de Janeiro) e Sul (Paraná, Santa Catarina, Rio Grande do Sul) (LABIAK; HIRAI, 2010). Ocorrendo também na Argentina, Uruguai, Peru, México, Bolívia e Paraguai (DISLICH, 1996).

Microgramma squamulosa também é uma espécies nativa não endêmica do Brasil, presente apenas em domínios fitogeográficos de Mata Atlântica. M. squamulosa ocorre no Sudeste (Minas Gerais, Espírito Santo, São Paulo, Rio de Janeiro) e Sul (Paraná, Santa Catarina, Rio Grande do Sul) do Brasil (LABIAK; HIRAI, 2010). Ocorrendo também no Uruguai, Argentina e Paraguai (DISLICH, 1996).

\subsection{Seleção de folhas}

Foram selecionadas as folhas de M.squamulosa e P.hirsutissima que estavam até aproximadamente $1,70 \mathrm{~m}$ de altura do solo, e na região do forófito em que cada espécie apresentava maior cobertura (presumimos que esta seja a região com as condições mais favoráveis para a espécie em questão). Ao todo foram selecionados quinze forófitos que apresentavam possibilidade de amostragem. Destes, três eram selecionados de forma intercalada a cada campanha de coleta de dados. 
As folhas selecionadas para estudo eram aquelas que se apresentavam sem sinais óbvios de dano. Para amostras referentes ao estado ativo, hidratado, foram amostradas folhas verdes e túrgidas para M.squamulosa e P.hirsutissima. No caso de P.hirsutissima em anabiose, eram selecionadas folhas com coloração verde e sem sinais de abscisão foliar. Foram excluídas da amostragem folhas jovens. Foram consideradas jovens, as folhas de M.squamulosa menores que $2 \mathrm{~cm}$ de comprimento, folhas enrugadas e com alta transparência. Foram consideradas jovens folhas de P.hirsutissima que possuíam o ápice da folha enrolado e com tricomas brancos. Foram consideradas folhas com sinais de dano aquelas que apresentavam amareladas, com sinais de predação e/ou outros danos no tecido.

\subsection{Análise dos padrões de uso de recursos}

Os procedimentos adotados foram dirigidos ao teste da hipótese de que o ganho de carbono na espécie com sinais de tolerância à dessecação mais abundante (TD) Pleopeltis hirsutissima é superior ou aproximado ao ganho da espécie sem respostas higroscópicas (SD) Microgramma squamulosa nas condições naturais de regime de suprimento hídrico e disponibilidade de luz.

As espécies (TD) e (SD) foram avaliadas quanto a assimilação de carbono e outros parâmetros das trocas gasosas durante o período de 26/08/2010 a 31/01/2012. Para descrever ambas as estratégias de uso da água (TD e SD), durante o mesmo período, foram avaliados parâmetros associados à dinâmica do uso da água (Condutância ao fluxo de vapor d'água, Transpiração e Eficiência do uso da água - ver glossário), assimilação líquida de carbono e dinâmica da capacidade de uso da luz (Rendimento quântico máximo do PSII, Rendimento quântico efetivo do PSII e Taxa de transporte de elétrons) e o estado de hidratação foliar (Conteúdo relativo de água).

\subsubsection{Padrões de uso da água e $\mathrm{CO}_{2}$}

Os padrões de uso da água e $\mathrm{CO}_{2}$ foram verificados através da análise de trocas gasosas com o auxílio do analisador de gás por infra-vermelho (Infrared Gas Analyser - IRGA), CIRAS. A taxa de fluxo do aparelho foi ajustada para $250 \mathrm{~mol}^{-1}$ e a razão estomática 0,5 . Os parâmetros estimados 
foram a assimilação de carbono (A), condutância ao fluxo de vapor d'água $\left(\mathrm{g}_{\mathrm{H} 2 \mathrm{O}}, \mathrm{mol}^{-2} \mathrm{~s}^{-1}\right)$ e transpiração $\left(\mathrm{J}_{\mathrm{H} 2 \mathrm{O}}, \mathrm{mmol} \mathrm{m}^{-2} \mathrm{~s}^{-1}\right)$. Todos os parâmetros descritos anteriormente foram obtidos a partir das equações descritas por Caemmerer e Farquhar (1981). Também foi estimada a eficiência na assimilação de carbono pela quantidade de água transpirada representada pela eficiência no uso da água (EUA) conforme descrito por Jones (1992).

Uma vez que os parâmetros estimados pelo analisador de gás por infravermelho dependem da área foliar, a área de ambas as espécies foram estimadas e levadas em consideração. Para as folhas de P.hirsutissima enroladas devido ao estado dessecado, a estimativa da área foi realizada após a sua reidratação.

\subsubsection{Capacidade de uso da luz}

A avaliação da capacidade de uso da luz que condiciona a assimilação de $C_{0} 2$ foi feita através da análise de fluorescência da clorofila a, empregandose a técnica de análise de fluorescência da clorofila por pulso modulado (SCHREIBER, 1986) com auxílio do sistema de monitoramento de fluorescência FMS2 da Hansatech e PAM 2000. A denominação dos parâmetros e sua definição seguem a terminologia definida por Krause e Weis (1984) e Genty, Briantais e Baker (1989) (ver glossário).

A integridade do fotossistema nas amostras, ou o rendimento quântico máximo aparente do PSII (Fv/Fm), foi estimada a partir da relação entre fluorescência variável $(\mathrm{Fv})$ e fluorescência máxima $(\mathrm{Fm})$ obtida por pulso saturante após 20 minutos de aclimatação das folhas ao escuro. A fluorescência variável foi obtida através da diferença entre a fluorescência máxima e a fluorescência basal ou inicial (Fo). Valores de Fv/Fm próximos a 0,8 foram tomados como a recuperação integral da capacidade de uso da luz (BJORKMAN; DEMMING, 1987).

O valor do rendimento quântico efetivo do PSII (Fv'/Fm') foi obtido após a aclimatação das folhas a uma intensidade luminosa de aproximadamente $300 \mu \mathrm{molm}^{2}{ }^{2} \mathrm{~s}$ durante dois minutos. O valor do $\mathrm{Fv}^{\prime} / \mathrm{Fm}^{\prime}$ foi estimado através da razão entre a fluorescência variável em estado adaptado a luz ( $\left.F^{\prime}{ }^{\prime}\right)$ e a fluorescência máxima em estado adaptado a luz $\left(F m^{\prime}\right)$. O valor de $F^{\prime}$ foi 
estimado a partir da diferença entre a Fm' e a fluorescência basal (Fs). A taxa de transporte de elétrons (ETR) foi calculada através da fórmula (DEMMIG; BJÖRKMAN, 1987; SCHREIBER, BILGER, NEUBAUER, 1994):

$$
\mathrm{ETR}=\mathrm{FFF} \cdot \mathrm{Fv}^{\prime} / \mathrm{Fm}^{\prime} \cdot 0,5 \cdot 0,84
$$

Em que FFF representa o fluxo de fótons fotossintéticos, o Fv'/Fm' representa o rendimento quântico efetivo do PSII. Sendo que aproximadamente $84 \%$ $(0,84)$ da luz é absorvida pelas moléculas de clorofila, com $50 \%(0,5)$ dos fótons ativando as moléculas de clorofila associada ao PSII e 50\% dos fótons ativando as moléculas associadas ao PSI.

\subsubsection{Conteúdo relativo de água (CRA)}

Para caracterizar o estado de hidratação foliar, todas as folhas coletadas e levadas para o laboratório foram pesadas com auxilio de uma balança de precisão com quatro casas após a vírgula. O conteúdo relativo de água foi estimado pela razão entre o peso fresco (Pf) subtraído do peso seco (Ps) e o peso fresco saturado (Psat) subtraído do peso seco (BARRS, 1968):

$$
C R A=(P f-P s) /(P s a t-P s)
$$

O peso saturado foi determinado após 24 a 48 horas das folhas estarem embebidas em água. O peso seco foi determinado após 48 a 72 horas na estufa a $60^{\circ} \mathrm{C}$.

\subsection{Procedimento de coleta}

A cada dia de coleta foram amostrados três forófitos e, em cada um dos forófitos foram mensurados três folhas de P.hirsutissima e três folhas de M.squamulosa, totalizando 9 folhas por espécie por dia. As folhas selecionados foram destacados e imediatamente inseridos na câmara do Analisador de Gás por Infra-vermelho e eram tomadas medidas de trocas gasosas (Assimilação de Carbono, Condutância ao fluxo de vapor d'água e Transpiração). Após a tomada de dados de trocas gasosas as folhas destacados foram levados para o laboratório. 
No laboratório foi mensurado o peso fresco das folhas coletadas e, logo em seguida foram mantidas em uma sala escura durante 20 minutos para aclimatar seus tecido (oxidação dos centros de reação) e permitir a mensuração do Fv/Fm através de técnicas de fluorescência da clorofila a. Após mensurar os valores de $\mathrm{Fv} / \mathrm{Fm}$, as folhas foram iluminadas durante 2minutos com uma luz de intensidade de $300 \mu \mathrm{molm}^{-}{ }^{2} \mathrm{~s}$ para possibilitar a tomada de medidas do rendimento quântico efetivo do PSII (Fv'/Fm') e taxa de transporte de elétrons (ETR). Por fim, as folhas foram mantidas imersas em potes com água para mensurar o peso saturado e em seguida foram mantidas na estufa para mensurar o peso seco e assim, juntamente com o valor do peso fresco obtido calcular o conteúdo relativo de água (CRA) foliar.

\subsection{Dados de pluviosidade}

Com o objetivo de testar a hipótese da assimilação de carbono foram obtidos dados diários de precipitação, de janeiro de 2010 a fevereiro de 2012, através da estação do Departamento de Ciências Atmosféricas do Instituto de Astronomia, Geofísica e Ciências Atmosféricas, localizada na Av. Miguel Stefano, 4200, Água Funda, São Paulo-SP.

Para descrever de forma mais efetiva as estratégias de uso da água (TD e SD), os dias de amostragem de P.hirsutissima e M.squamulosa foram divididos entre período úmido e período seco. Essa divisão foi realizada de acordo com o acúmulo de chuva estimado através da seguinte equação:

Acúmulo de precipitação $=($ vol_d1/1) $+($ vol_d2/2 $)+($ vol_d3/3 $)+($ vol_d4/4 $)+$ (vol_d5/5)

Sendo vol_d1 o volume de chuva precipitado do dia anterior ao dia amostrado, vol_d2 o volume de chuva precipitado no segundo dia anterior ao dia amostrado e assim sucessivamente até ao quinto dia anterior ao dia amostrado.

Foi considerado período úmido os dias em que o acúmulo de chuva estimado foi superior a $15 \mathrm{~mm}$ e período seco aqueles dias em que o acúmulo de chuva estimado não ultrapassou de $1 \mathrm{~mm}$. O corte que separou o período úmido do período seco foi feito de forma arbitrária, através da observação da 
variação do CRA em P.hirsutissima em função ao do acúmulo de água mensurado (Figura 2). Desta forma, dos 46 dias amostrados, 16 dias foram considerados para as análises durante o período úmido e 8 dias amostrados considerados nas análises para o período seco. Os 22 dias restantes foram considerados como período de transição entre o período úmido e o período seco.

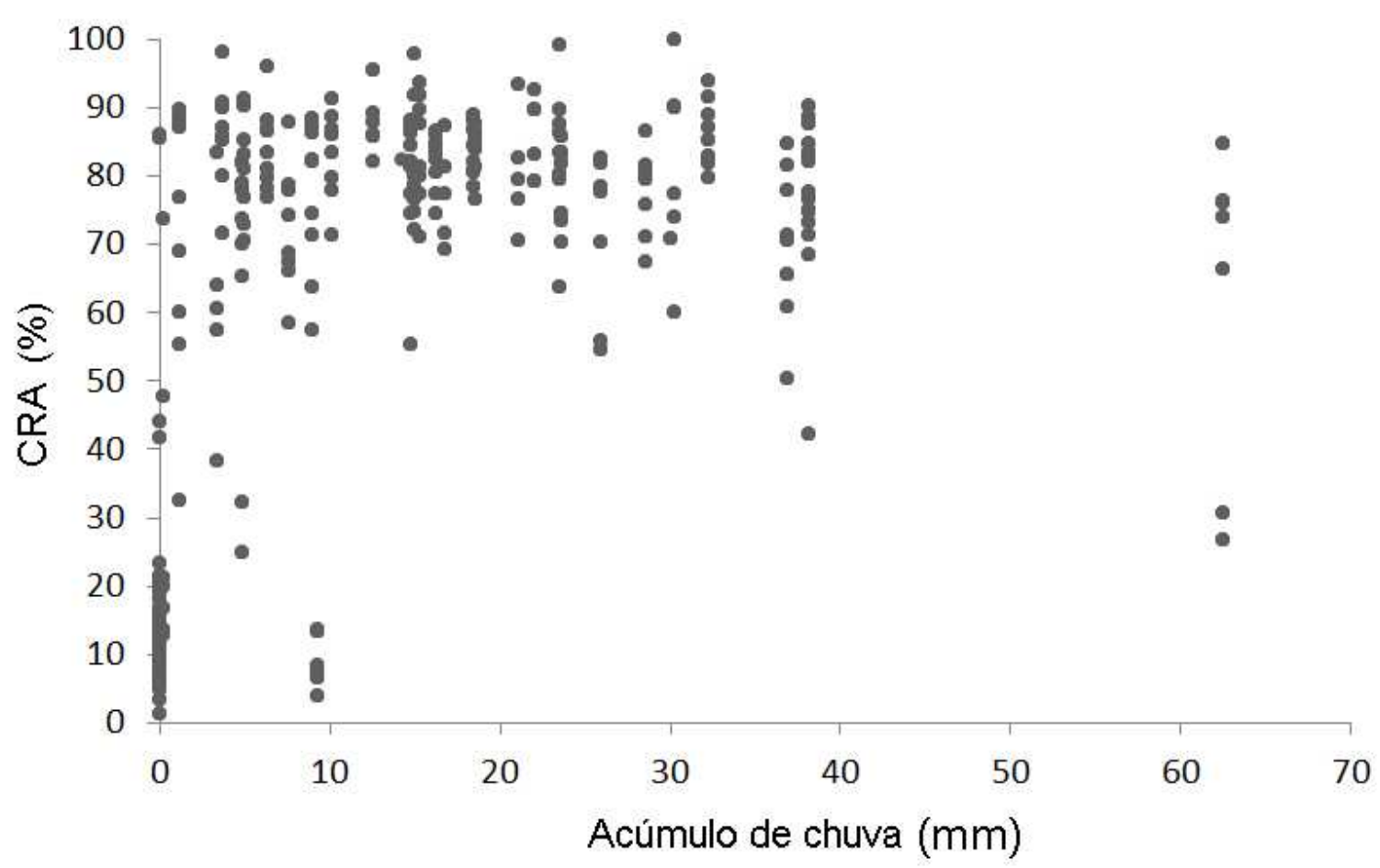

Figura 2 - Conteúdo relativo de água (CRA \%) da espécie Pleopeltis hirsutissima pelo acúmulo de chuva mensurado (conforme descrito no texto). Os dias de coleta que apresentaram acúmulo de chuva superiores a $15 \mathrm{~mm}$ foram considerados nas análises como pertencentes ao período ao período úmido, os inferiores a $1 \mathrm{~mm}$ foram considerados pertencentes ao período seco e entre esses valores $(1 \mathrm{~mm}-15 \mathrm{~mm})$ foram considerados pertencentes ao período de transição

\subsection{Componentes de interação com a luz}

Com intuito de verificar a interação de espécies TD e SD com a luz e procurar indícios da diferenciação de nichos, foram mensurados o conteúdo de pigmentos fotossintéticos, os componentes da curva de resposta a luz (assimilação máxima, ponto de compensação luminoso e eficiência quântica) e foi realizado um ensaio para avaliar os efeitos da interação entre luz e suspensão da provisão hídrica. 


\subsubsection{Pigmentos fotossintetizantes}

Foi analisado o conteúdo de clorofila $a$, clorofila b, carotenóides, pigmento total (soma da clorofila a, clorofila b e carotenoides) e a razão entre a clorofila a e b em P.hirsutissima e M.squamulosa. A cada dia de coleta foram selecionados 5 forófitos e de cada um foram coletadas 3 folhas de M.squamulosa e 3 folhas de P.hirsutissima visíveis da face norte e 3 folhas de M.squamulosa e 3 folhas de P.hirsutissima inseridas na face sul do forófito. A coleta de folhas foi dividida entre a face norte e face sul dos forófitos devido a fonte evidente de variação na quantidade de luz recebida em ambos os lados. Ao todo foram realizados doze dias de coleta, porém em apenas oito dias foram tomadas medidas de peso para mensurar o conteúdo relativo de água.

A seleção dos forófitos amostrados foi realizada por meio de busca ativa daqueles que apresentavam as condições previamente estabelecidas: o forófito apresentar ambas as espécies (Pleopeltis hirsutissima e Microgramma squamulosa) e que ambas tivessem folhas visíveis da face norte e inseridas na face sul do forófito. As coletas foram realizadas revezando entre dois trechos, o primeiro na Av. Professor Mello Moraes e o segundo trecho que começava na Rua do Matão até a Av. Professor Lineu Prestes.

Foram tirados três discos foliares (ápice, meio e base da folha) com $2,9 \mathrm{~mm}$ de diâmetro de cada folha ou ramo, obtendo-se uma área total de $0,198 \mathrm{~cm}^{2}$. Os três discos retirados foram colocados em um eppendorf com $2 \mathrm{ml}$ de solução de DMSO (Dimetilsulfóxido) e mantidos durante uma semana em um ambiente escuro para a extração dos pigmentos. Para estimar o conteúdo de clorofilas e carotenóides, após a extração dos pigmentos, a solução foi submetida à leitura de absorbância em espectrofotômetro (UV -100 -01, Shiamadzu, Japão) nos comprimentos de onde de 480, 649 e 665nm de acordo com Wellburn (1994).

\subsubsection{Curva de resposta à luz}

Foram realizadas curvas de luz em cinco folhas de M.squamulosa e cinco folhas de $P$.hirsutissima em estado saturado. As curvas foram realizadas com a intensidade de luz variando de $300 \mathrm{a} 0 \mu \mathrm{mol} \mathrm{m} \mathrm{m}^{-2} \mathrm{~s}^{-1}$, sendo a intensidade 
luminosa reduzida gradativamente a cada $20 \mu \mathrm{mol} \mathrm{m} \mathrm{m}^{-2} \mathrm{~s}^{-1}$. Também foram feitas curvas de luz acompanhando o dessecamento de duas folhas de P.hirsutissima e duas folhas de M.squamulosa, durante cinco dias. Para ambos os casos, o forófito foi irrigado por um aspersor durante aproximadamente doze horas antes do início das medições, sendo que as plantas já se encontravam em estado hidratado antes do inicio da irrigação. Foram selecionadas as folhas que não apresentavam danos visíveis nos tecidos e que apresentaram valor de Fv/Fm superior a 0,75 no primeiro dia de medição.

As curvas de resposta à luz foram analisadas através do ajuste de curva do programa OriginPro 8.6 com a utilização do modelo não linear de hipérbole não-quadrática:

$$
y=A^{*}\left(1-\exp \left(-k^{*}(x-x c)\right)\right)
$$

em que $A$ representa a assimilação máxima $\left(\mu \mathrm{mol} \mathrm{m} \mathrm{m}^{-2} \mathrm{~s}^{-1}\right), x c$ representa 0 ponto de compensação luminosa $\left(\mu \mathrm{mol} \mathrm{m}^{-2} \mathrm{~s}^{-1}\right)$ e o $\mathrm{k}$ apresenta a rendimento quântico aparente da assimilação $\left(\mu \mathrm{mol} \mathrm{m}^{-2} \mathrm{~s}^{-1}\right)$.

\subsubsection{Efeitos da interação entre luz e suspensão da provisão hídrica}

Foram coletados doze fragmentos de troncos, sendo que seis deles possuíam M.squamulosa e os outros seis P.hirsutissima. Por meio de sorteio os fragmentos foram separados igualmente entre dois tratamentos. Os pedaços de tronco foram mantidos em casa de vegetação sem água durante um mês sendo que, em um tratamento os fragmentos contendo epífitas foram mantidos expostos à luz do dia filtrada pelo revestimento da estufa (intensidade luminosa máxima de aproximadamente $1200 \mu \mathrm{mol} \mathrm{m}^{-2} \mathrm{~s}^{-1}$ ) enquanto no segundo tratamento os fragmentos contendo epífitas foram mantidos sombreados (controle) sob duas camadas de sombrite, reduzindo a intensidade luminosa a aproximadamente $50 \mu \mathrm{mol} \mathrm{m} \mathrm{m}^{-2} \mathrm{~s}^{-1}$.

Em cada fragmento de tronco foram marcadas todas as folhas que aparentavam ausência de danos ou estresse e dessas foram sorteadas cinco folhas. Após uma semana de aclimatação em estado hidratado em casa de vegetação foi mensurado o potencial de uso da luz $(\mathrm{Fv} / \mathrm{Fm})$ das folhas sorteadas para verificar o estado do aparato fotossintético. As folhas que apresentaram um valor de $\mathrm{Fv} / \mathrm{Fm}$ menor do que 0,75 foram descartadas e uma 
nova folha foi sorteada e verificada em seu lugar, assim até que todos os fragmentos tivessem cinco folhas com valores de $\mathrm{Fv} / \mathrm{Fm}$ igual ou maior do que 0,75 . Foram tomadas medida de $\mathrm{Fv} / \mathrm{Fm}$ das folhas selecionadas após um mês do início do experimento, no qual os fragmentos foram submetidos a suspensão da provisão hídrica, e doze horas após o início da reidratação dos forófitos.

\subsection{Análise dos dados}

\subsubsection{Testes de hipóteses}

Para caracterizar as estratégias de uso da água TD e SD, foi realizada uma análise descritiva e exploração de conjuntos de dados para distinção de multimodalidade por meio de uma análise de mistura baseada em distribuições gaussianas testando-se dois ou três componentes. As hipóteses foram testadas através de modelos paramétricos como a análise de modelos lineares. De forma a facilitar, o número de amostra para cada análise foi indicado durante os resultados. Para todas as análises o alfa crítico considerado foi de 0,05 .

\subsubsection{Tratamento de outliers}

Com o intuito de distinguir os estados fisiológicos atingidos pelas espécies TD e SD, os dados obtidos foram analisados de forma integral com a análise de mistura, ou seja, sem a retirada de outliers. Para as demais análises os dados foram inspecionados e os outliers foram removidos com intuito de descrever as estratégias TD e SD utilizando apenas folhas saudáveis.

\subsubsection{Testes de médias}

Para testar a hipótese de que P.hirsutissima apresenta taxas fotossintéticas compensatórias, apresentando fixação de carbono superior a M.squamulosa durante os períodos de chuva, foi realizada a comparação de médias através do teste $t$ de student, para hipótese unicaudal. A comparação da assimilação de carbono entre as espécies TD e SD durante o período seco foi testada através de teste t de student para hipótese bicaudal. Para testar 0 
fator período (úmido e seco) também foi utilizada comparação de médias através do teste t de student para hipótese bicaudal.

As diferenças do conteúdo de pigmentos entre folhas de P.hirsutissima e M.squamulosa presentes na face norte e na face sul dos forófitos foram testadas através do método de PERMANOVA de duas vias, utilizando métrica de distância euclidiana.

\subsubsection{Testes não-paramétricos}

Para testar o fator espécie, nas variáveis cuja distribuição não apresentaram parâmetros aproximados da normal e nem eram homocedásticas entre si foram empregadas análises de comparação de grupos de amostras independentes através do teste de Mann-Whitney. 


\section{Resultados}

3.1. Análise da estrutura da comunidade de epífitas

As espécies de pteridófitas tolerantes à dessecação presentes na cidade universitária são: Pleopeltis astrolepis, Pleopeltis hirsutissima, Pleopeltis pleopeltifolia e Pleopeltis polypodioides; e as espécies sensíveis a dessecação são: Microgramma squamulosa, Microgramma vaccinifolia e Serpocaulon catharinae. Todas as espécies são integrantes da família Polypodiaceae.

A espécie mais frequente na arborização urbana da Cidade Universitária foi a espécie sensível a dessecação (SD) Microgramma squamulosa, presente em 96 dos 114 dos forófitos observados (84,21\%). Em seguida a maior frequência foi de Pleopeltis hirsutissima, presente em 80 forófitos $(70 \%)$ e Pleopeltis pleopeltifolia em 58 forófitos $(51 \%)$. Ainda relativamente frequentes foram as bromélias do tipo tillandsioide em 46 forófitos e Pleopeltis astrolepis em 42 forófitos. Uma pequena proporção de árvores amostrada (10\%) não apresentava qualquer epífita (Tabela 2; Figura 3). Comparando às estratégias de uso da água TD e SD a frequência obtida foi semelhante. Ao todo, espécies SD foram avistadas 195 vezes contra 182 vezes em TD, logo a cada forófito amostrado havia uma frequência média de 1,7 espécies SD para 1,6 espécies TD.

A pteridófita M.squamulosa aparece também como a mais abundante, cobrindo em média $44 \pm 27,6 \%$ dos forófitos em que está presente. Em segundo lugar esta a espécie SD Microgramma vaccinifolia com 37,50\% (observada em apenas um forófito) e em terceiro a espécie TD Pleopeltis polypodioides com $23,08 \pm 3.157 \%$. P.hirsutissima aparece em quarto lugar, cobrindo em média $16,18 \pm 13,28 \%$ (Tabela 2 ). 
Tabela 2 - Frequência (\%) e abundância absoluta (\%) de espécies de epífitas vasculares da arborização do Campus da CUASO

\begin{tabular}{lcc}
\hline Espécie / Tipo & Frequência (\%) & Abundância (\%) \\
\hline Microgramma squamulosa (ms) & 84,21 & $44,586 \pm 27,588$ \\
Pleopeltis hirsutissima (ph) & 70,17 & $16,182 \pm 13,282$ \\
P. pleopeotifolia (ppleo) & 51,87 & $12,689 \pm 10,152$ \\
Tillandsia sp. (tllan) & 40,35 & $4,790 \pm 7,138$ \\
P. astrolepis (past) & 36,84 & $3,937 \pm 3,828$ \\
Bromélias tanque (brom) & 21,05 & $8,696 \pm 13,012$ \\
Aechmea distichantha & & \\
A.bromeliifolia & & \\
Vriesea sp. & & \\
Rhipsalis sp. (riph) & 13,15 & $15,030 \pm 9,154$ \\
S. catharinae (pc) & 10,52 & $5,983 \pm 5,572$ \\
P. polypodioides (ppol) & 1,75 & $23,076 \pm 3,156$ \\
M. vaccinifolia (mv) & 0,87 & $37,5 \pm 0,00$ \\
Orchidaceae (orch) & 0,87 & $3,365 \pm 0,00$ \\
\hline
\end{tabular}

* 9,65\% dos forófitos amostrados não apresentaram nenhuma epífita associada 


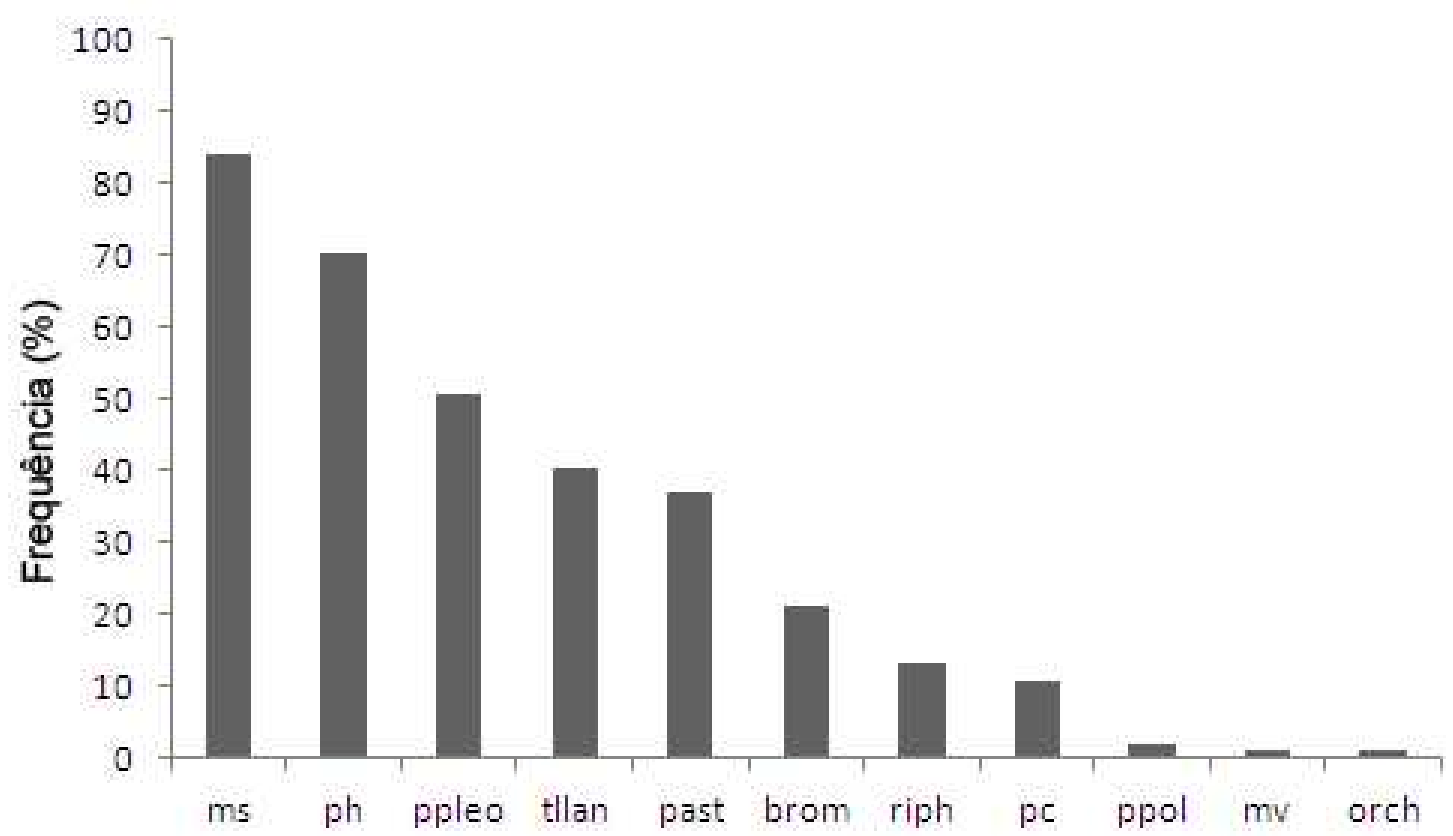

Figura 3 - Frequência de espécies e tipos de epífitas presentes nas arvores da arborização do Campus da CUASO, levantado no período de Jan-Março de 2010. Microgramma squamulosa (ms), Pleopeltis hirsutissima (ph), Pleopeltis pleopeltifolia (ppleo), Tillandsia sp. (tllan), Pleopeltis astrolepis (past), Bromeliaceae (brom), Rhipsalis sp. (riph), Serpocaulon catharinae (pc), Pleopeltis polypodioides (ppol), Microgramma vaccinifolia (mv), Orchidiaceae (orch).

A análise de ordenação permitiu a detecção de $49,7 \%$ da variação total da matriz nos dois primeiros eixos sendo 26,6 e 23,1\% correspondentes, respectivamente ao $1^{\circ}$ e ao $2^{\circ}$ eixos resultantes da ordenação. A interpolação dos escores correspondentes a espécies e forófitos nos dois primeiros eixos está representada na figura 4. O padrão apresentado permite sugerir a existência de dois grupos com ocorrência associada e um elemento isolado. Os dois grupos são bem caracterizados e correspondem a: - 1) bromélias-tanque; Rhipsalis sp. e Serpocaulon catharinae. - 2) Microgramma squamulosa; Pleopeltis pleopeltifolia; Pleopeltis hirsutissima e Pleopeltis astrolepis. O elemento externo corresponde à bromeliácea do gênero Tillandsia.

Os escores referentes aos forófitos obtidos nos 3 primeiros eixos foram utilizados para testar a segregação de grupos de forófitos no arranjo final da ordenação. Em uma análise de variância utilizando-se o sítio como variável 
independente e os escores como dependentes, os valores correspondentes ao primeiro eixo distinguem a maioria (6 dos 8$)$ dos sítios analisados ( $F=136,3$; $p<0,01)$, conforme a análise de comparações múltiplas de Student Newman Keuls.

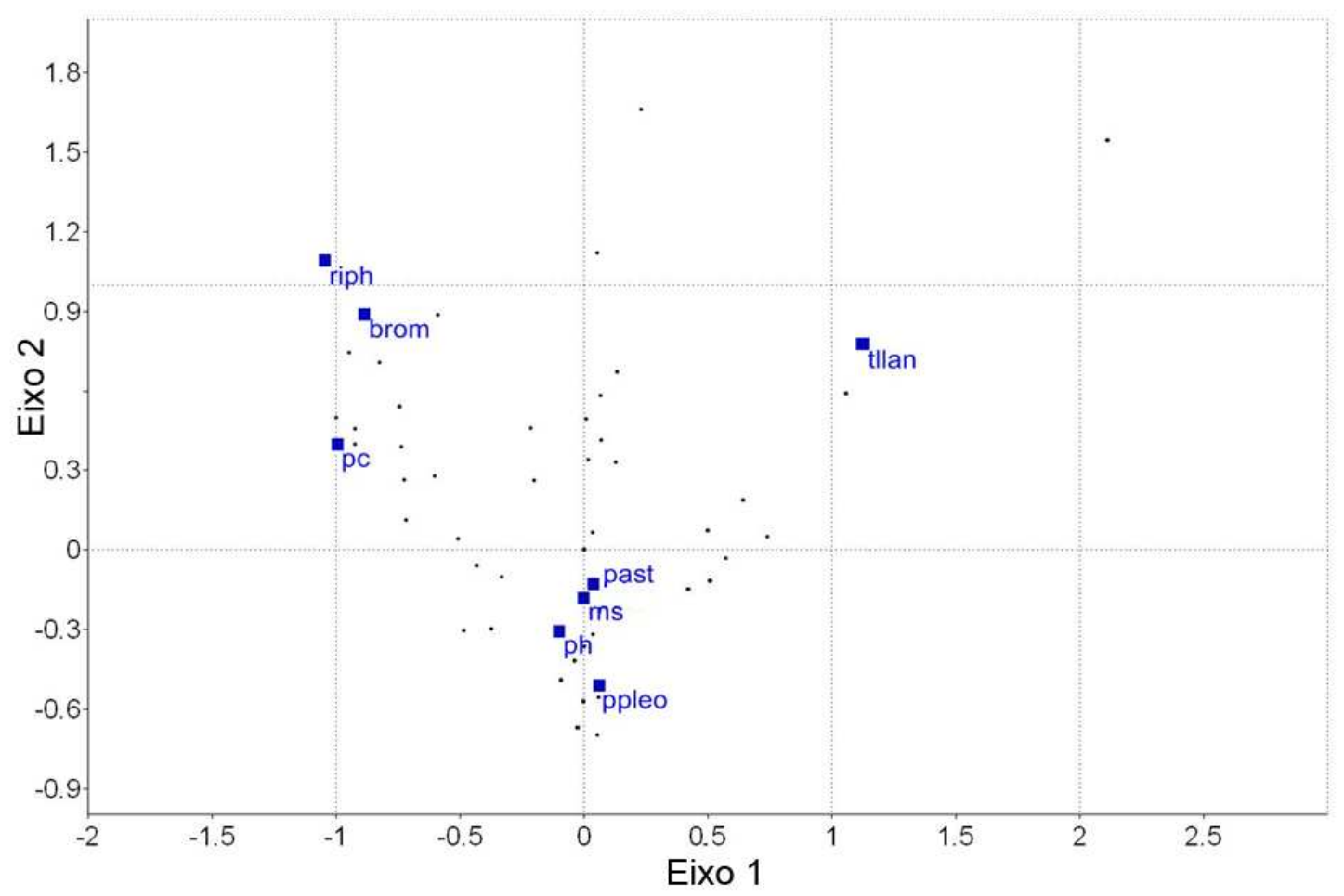

Figura 4 - Interpolação dos escores obtidos para os dois primeiros eixos através da análise de correspondência aplicada à matriz de ocorrências de epífitas em forófitos da arborização da CUASO. Os pontos correspondem a forófitos (árvores) e os quadrados à epífitas com ocorrência em mais do que 2 forófitos. Os autovalores correspondentes representam, respectivamente 26,6 e $23,1 \%$ da informação contida na matriz, totalizando $49,7 \%$ no arranjo apresentado. As siglas correspondem a : riph (Rhipsalis sp.); brom (broméliastanque); pc (Serpocaulon catharinae); past (Pleopeltis astrolepis); ms (Microgramma squamulosa); ph (Pleopeltis hirsutissima); ppleo (Pleopeltis pleopeltifolia) e tllan (Tillandsia sp.).

O resultado obtido a partir da análise de agrupamento aplicada à matriz de similaridade de Jaccard utilizando-se os algoritmos de média de grupo (UPGMA) resultou em um arranjo com 0,97 de coeficiente cofenético, representado no dendrograma de similaridade (Figura 5). O dendrograma obtido permite distinguir claramente dois grupos, coerentes como o arranjo 
sugerido na análise de correspondência com exceção da inclusão de epífitas do genêro Tillandsia no grupo formado pelas espécies de Pleopeltis e Microgramma. Os grupos formados são portanto o de bromélia-tanque, Rhipsalis sp. e Serpocaulon catharinae e aquele de Pleopeltis sp., Microgramma squamulosa e Tillandsia sp.

O arranjo obtido verificado na análise de cluster (Figura 6) aplicada ao escores das espécies nos 4 primeiros eixos obtidos na análise de correspondência corrobora a definição do grupo formado por espécies de Pleopeltis e Microgramma squamulosa e evidencia a associação entre o tipo "bromélias-tanque" e cactáceas do gênero Rhipsalis. O tipo "tillandsióide" apresenta um padrão de ocorrência distinto dos demais e a espécie Serpocaulon catharinae apresenta uma pequena associação com o grupo de bromélia-tanque e cactáceas. 


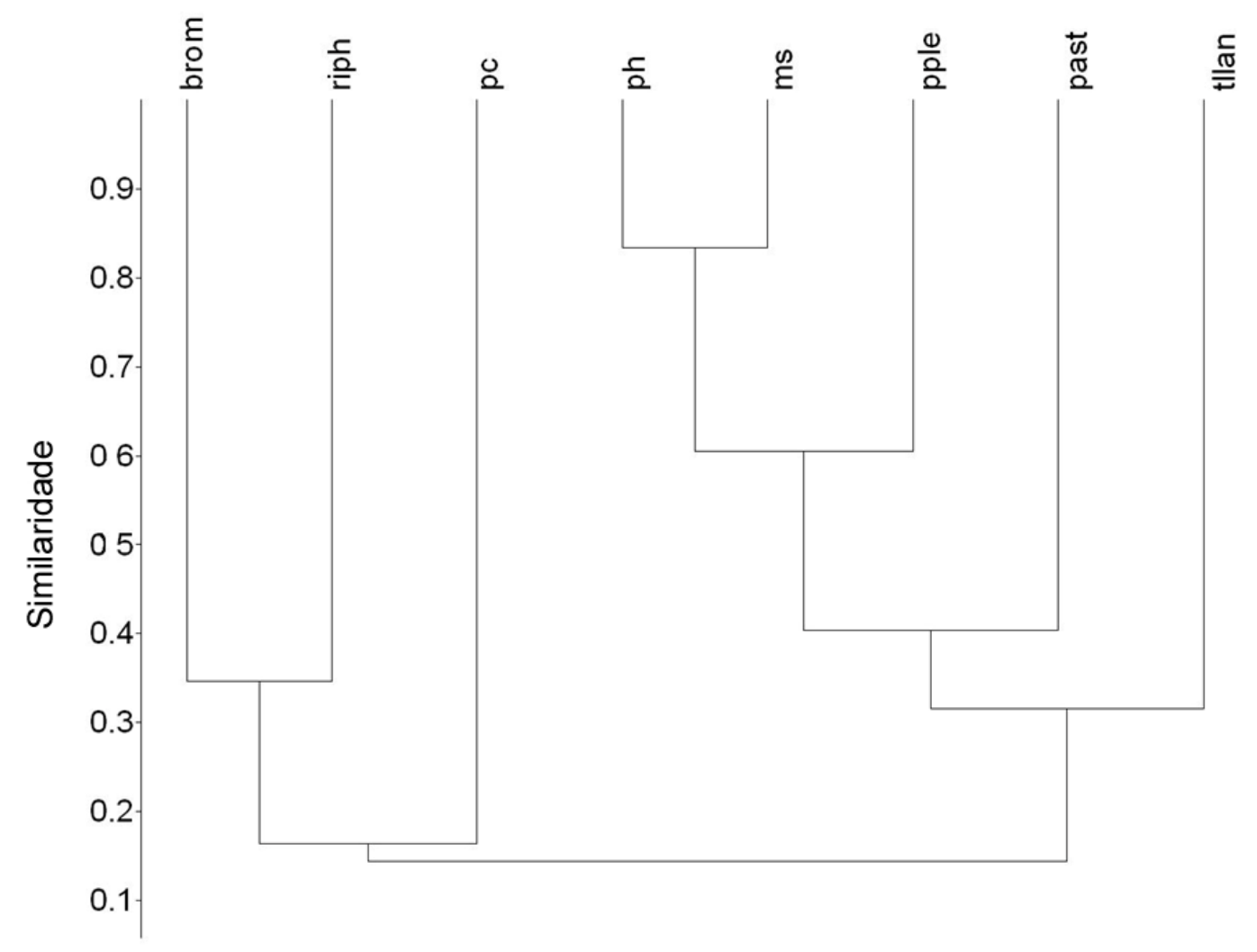

Figura 5 - Dendrograma de similaridade empregando o algoritmo de média de grupo aplicado à matriz de similaridade de Jaccard, calculada a partir da matriz de ocorrências de epífitas em forófitos da arborização da CUASO - SP. O coef. cofenético do arranjo apresentado é de 0,9682. As espécies/tipos apresentados são: riph(Rhipsalis sp.); brom(bromélias-tanque); pc(Serpocaulon catharinae); past(Pleopeltis astrolepis); ms(Microgramma squamulosa); ph(Pleopeltis hirsuti ssima); ppleo(Pleopeltis pleopeltifolia) e tllan(Tillandsia sp.). 


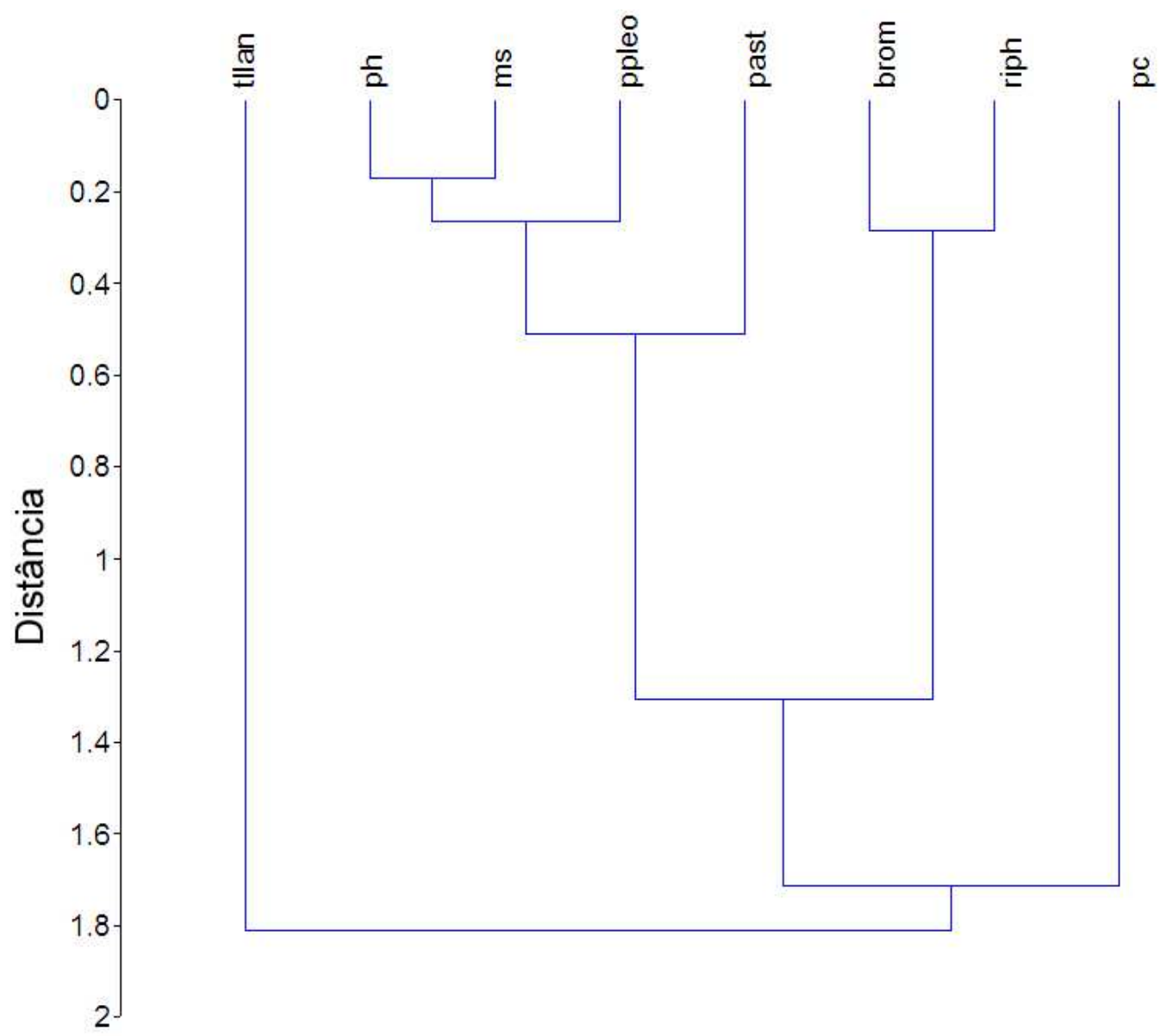

Figura 6 - Dendograma resultante da análise de agrupamento (cluster) aplicada aos escores obtidos pelas espécies nos 4 primeiros eixos resultantes da análise de correspondência aplicada à matriz de ocorrência de epífitas em forófitos. O dendrograma foi obtido através do algoritmo de média de grupo aplicada à matriz de distâncias de Mahalanobis (coef. cofenético $=0,97$ ). As espécies/tipos apresentados são riph (Rhipsalis sp.); brom (bromélias-tanque); pc (Serpocaulon catharinae); past (Pleopeltis astrolepis); ms (Microgramma squamulosa); ph (Pleopeltis hirsutissima); ppleo (Pleopeltis pleopeltifolia) e tllan (Tillandsia sp.). O arranjo apresentado é compatível com a existência de um conjunto associado correspondente às Pleopeltis sp. e Microgramma squamulosa já verificado nos dados originais. 


\subsection{Dinâmica das estratégias de uso da água}

\subsubsection{Assimilação de carbono}

Durante todo o período estudado P.hirsutissima apresentou uma média de assimilação igual a 2,034 $\pm 1,732 \mu \mathrm{mol} \mathrm{m}^{-2} \mathrm{~s}^{-1}$, com máximo de 6,7 e mínimo de $-2,600 \mu \mathrm{mol} \mathrm{m} \mathrm{m}^{-2} \mathrm{~s}^{-1}$ e M.squamulosa apresentou uma média de $2,253 \pm 1,467 \mu \mathrm{mol} \mathrm{m} \mathrm{m}^{-2} \mathrm{~s}^{-1}$, com máximo de 6,7 e mínimo de $-0,70 \mu \mathrm{mol} \mathrm{m} \mathrm{m}^{-2} \mathrm{~s}^{-1}$.

Durante o período úmido (acúmulo de chuva $>15 \mathrm{~mm}$ ) P.hirsutissima apresentou uma média de assimilação igual a $2,914 \pm 0,120 \mu \mathrm{mol} \mathrm{m} \mathrm{m}^{-2} \mathrm{~s}^{-1} \mathrm{com}$ máximo de 6,60 e mínimo de $-0,40$,e M.squamulosa apresentou uma assimilação média igual a $2,806 \pm 0,101 \mu \mathrm{mol} \mathrm{m}^{-2} \mathrm{~s}^{-1}$ com máximo de $5,8 \mathrm{e}$ mínimo de -0,130. Durante o período seco (acúmulo de chuva $<1 \mathrm{~mm}$ ) $P$.hirsutissima apresentou uma média de assimilação igual a $-0,050 \pm 0,020 \mu \mathrm{mol} \mathrm{m} \mathrm{m}^{-2} \mathrm{~s}^{-1}$ com valor máximo de 0,34 e mínimo de $-0,71 \mu \mathrm{mol} \mathrm{m} \mathrm{m}^{-2} \mathrm{~s}^{-1}$ M.squamulosa, apesar de manter suas folhas verdes, também mostrou redução de sua assimilação de carbono, apresentando uma média igual a 0,896 $\pm 0,114 \mu \mathrm{mol} \mathrm{m} \mathrm{m}^{-2} \mathrm{~s}^{-1}$, com máximo de 4,10 e mínimo de $-0,30 \mu \mathrm{mol} \mathrm{m} \mathrm{m}^{-2} \mathrm{~s}^{-1}$ (Tabela 3).

Tabela 3 - Assimilação líquida de carbono $\left(\mu \mathrm{mol} \mathrm{m}^{-2} \mathrm{~s}^{-1}\right)$ apresentada pelas espécies M.squamulosa e P.hirsutissima durante todo o período amostrado, durante o período seco e período úmido. Os valores apresentados na tabela são média, desvio padrão, máximo e mínimo

\begin{tabular}{|c|c|c|c|}
\hline Espécie & $\begin{array}{l}\text { Período todo } \\
\left(\mu \mathrm{mol} \mathrm{m}{ }^{-2} \mathrm{~s}^{-1}\right)\end{array}$ & $\begin{array}{l}\text { Período seco } \\
\left(\mu \mathrm{mol} \mathrm{m}{ }^{-2} \mathrm{~s}^{-1}\right)\end{array}$ & $\begin{array}{l}\text { Período úmido } \\
\left(\mu \mathrm{mol} \mathrm{m}^{-2} \mathrm{~s}^{-1}\right)\end{array}$ \\
\hline M. squamulosa & $\begin{array}{c}2,252 \pm 1,467 \\
(\text { de }-0,7 \text { a } 6,7)\end{array}$ & $\begin{array}{c}0,896 \pm 0,114 \\
\text { (de } 0,30 \text { a } 4,10 \text { ) }\end{array}$ & $\begin{array}{c}2,806 \pm 0,101 \\
\text { (de- } 0,130 \text { a } 5,8)\end{array}$ \\
\hline P. hirsutissima & $\begin{array}{c}2,034 \pm 1,732 \\
(\mathrm{de}-2,6 \text { a } 6,7)\end{array}$ & $\begin{array}{c}-0,050 \pm 0,020 \\
(\text { de }-0,71 \text { a } 0,34)\end{array}$ & $\begin{array}{l}2,914 \pm 0,1200 \\
(\text { de }-0,40 \text { a } 6,6)\end{array}$ \\
\hline
\end{tabular}


Durante o período úmido P.hirsutissima e M.squamulosa não apresentaram diferença quanto à assimilação de carbono (Figura 7). Apesar de P. hirsutissima $(n=157)$ apresentar uma tendência de maior assimilação, obtendo média mais elevada do que M.squamulosa ( $n=155)$, essa diferença não foi significativa ( $p=0,246$, teste $t$, unicaudal Ho: Aph $>$ Ams). Durante $o$ período seco M.squamulosa apresentou uma assimilação média maior do que a verificada em P.hirsutissima ( $p<0,001, n=84(p h), n=90(m s)$, teste $t$, bicaudal, Ho: Aph =Ams) (Figura 8).

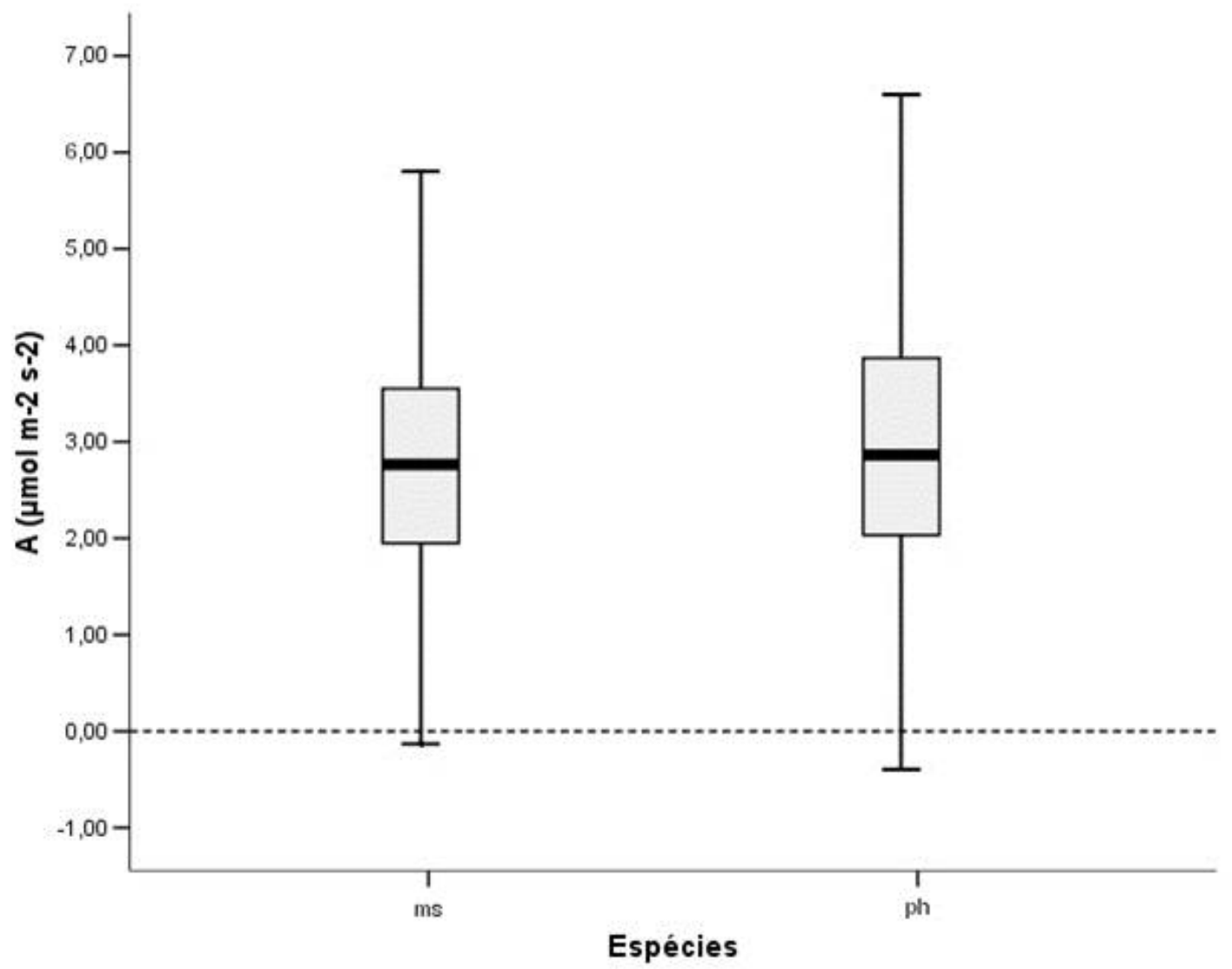

Figura 7 - Boxplot representando a assimilação de carbono (A) $\left(\mu \mathrm{mol} \mathrm{m} \mathrm{m}^{-2} \mathrm{~s}^{-1}\right)$ durante 0 período úmido (acúmulo de chuva $>15 \mathrm{~mm}$ ) de Microgramma squamulosa (ms) e Pleopeltis hirsutissima (ph). 


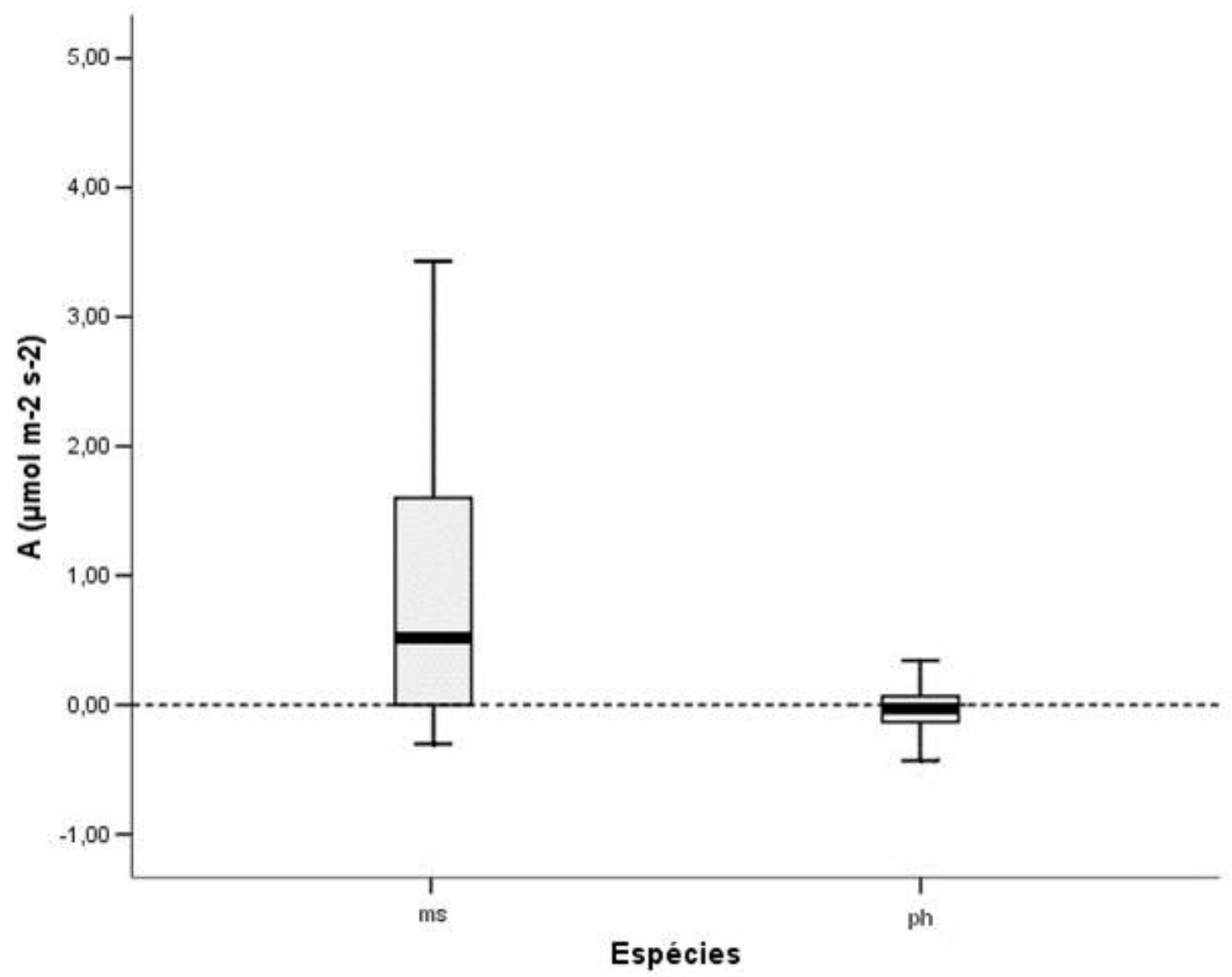

Figura 8 - Boxplot representando a assimilação de carbono (A) $\left(\mu \mathrm{mol} \mathrm{m} \mathrm{m}^{-2} \mathrm{~s}^{-1}\right)$ durante o período seco (acúmulo de chuva $>15 \mathrm{~mm}$ ) de Microgramma squamulosa (ms) e Pleopeltis hirsutissima (ph).

Através da análise de modelo de mistura para a assimilação de carbono foi possível distinguir dois subgrupos, ou estados fisiológicos, em M.squamulosa (Figura 9). O primeiro subgrupo obteve uma média igual a $0,908 \pm 2,485 \mu \mathrm{mol} \mathrm{m} \mathrm{m}^{-2} \mathrm{~s}^{-1}$ que inclui a maior parte dos valores de assimilação (probabilidade de ocorrência 0,915 ) e o segundo subgrupo apresentou média de $\quad-0,050 \pm 0,112 \mu \mathrm{mol} \mathrm{m} \mathrm{m}^{-2} \mathrm{~s}^{-1} \quad$ (probabilidade de ocorrência 0,092). P. hirsutissima também apresentou dois subgrupos (Figura 10). A primeira subpopulação apresentou média igual a 2,725 $\pm 1,146$ (probabilidade de ocorrência 0,750 ) e a segunda subpopulação apresentou média de $0,030 \pm 0,156 \mu \mathrm{mol} \mathrm{m} \mathrm{m}^{-2} \mathrm{~s}^{-1}$ (probabilidade de ocorrência 0,250 ). 


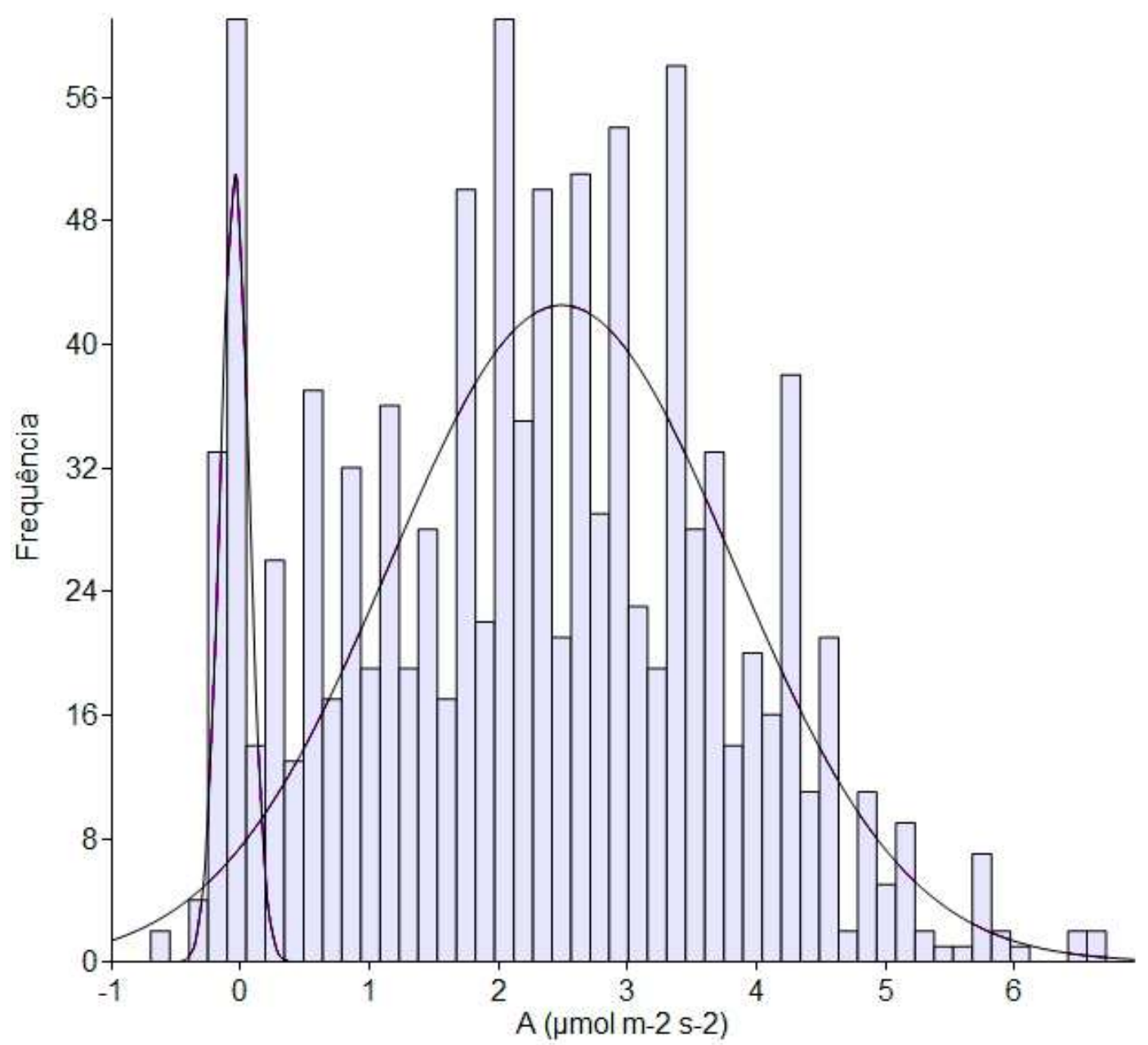

Figura 9 - Histograma de frequência resultante da análise de mistura da assimilação de carbono (A) ( $\mu \mathrm{mol} \mathrm{m}^{-2} \mathrm{~s}^{-2}$ ) em Microgramma squamulosa durante todo o período coletado. A primeira subpopulação apresentou uma média igual a 0,9084 \pm 2.485 e probabilidade de ocorrência 0,915 (à direita) e a segunda apresentou média de $-0.050 \pm 0.112$ e probabilidade de ocorrência 0,092 (à esquerda). Para esse ajuste o valor de Log I.hood foi de -854.6 e de Akaike IC 1717. 


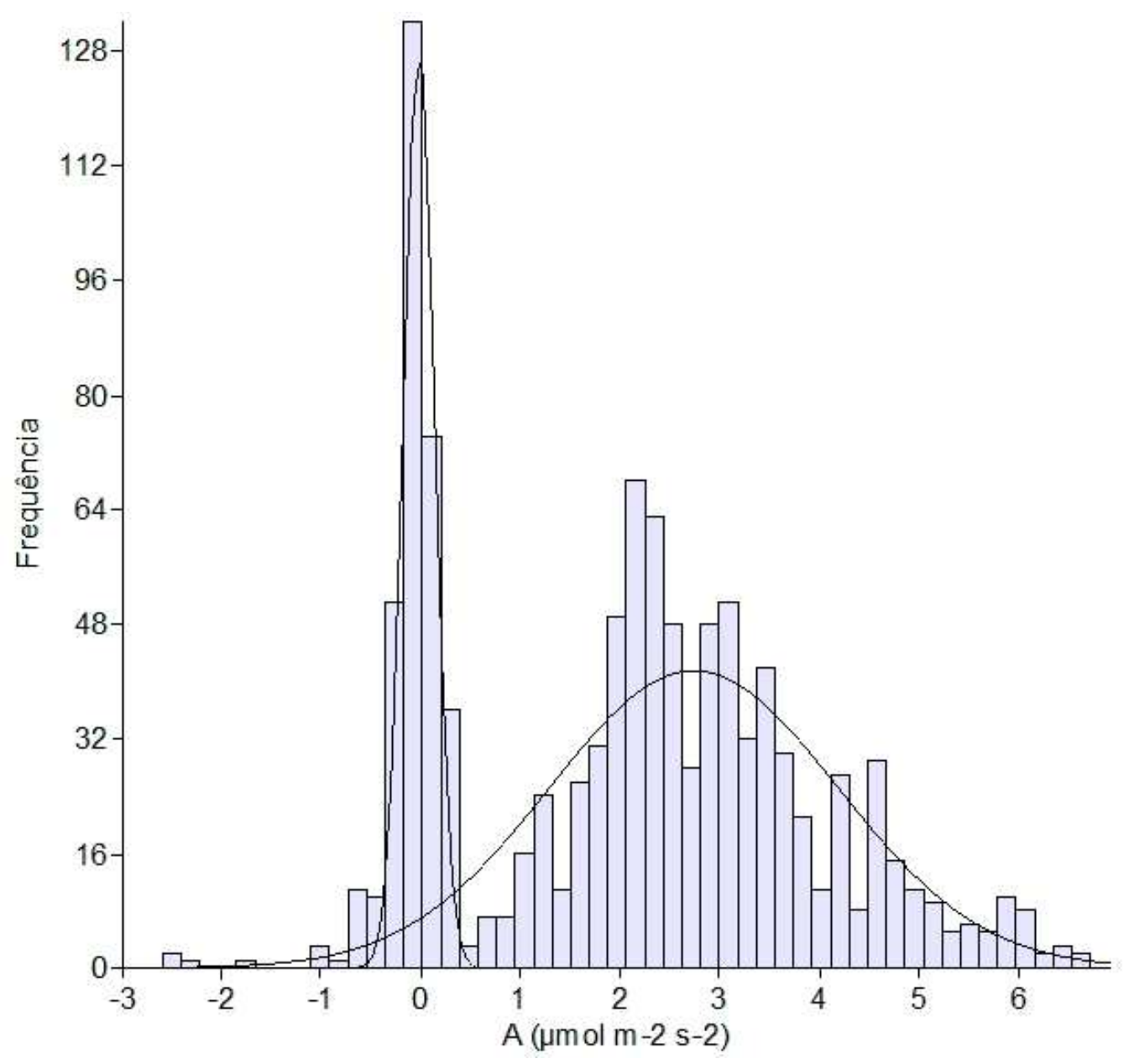

Figura 10 - Histograma de frequência resultante da análise de mistura da assimilação de carbono $(A)\left(\mu \mathrm{mol} \mathrm{m} \mathrm{m}^{-2} \mathrm{~s}^{-1}\right)$ em Pleopeltis hirsutissima durante todo o período coletado. Primeira subpopulação apresentou média igual a $2,725 \pm 1,146 \mu \mathrm{mol} \mathrm{m} \mathrm{m}^{-2} \mathrm{~s}^{-2}$ e probabilidade de ocorrência 0,750 (à direita) e segunda subpopulação e de $-0,030 \pm 0,156 \mu \mathrm{mol} \mathrm{m}^{-2} \mathrm{~s}^{-1}$ e probabilidade de ocorrência 0,250 (à esquerda). Para esse ajuste o valor de Log I.hood foi de 849 e de Akaike IC 1706. 


\subsubsection{Conteúdo relativo de água}

Durante todo o período amostrado P. hirsutissima apresentou uma média igual a $62,875 \pm 30,860 \%$ e CRA máximo de $100 \%$ e mínimo absoluto de $1,3 \%$, em contraste, o conteúdo relativo de água de Microgramma squamulosa se manteve estável, apresentando uma média de $97 \pm 1,53 \%$, com CRA máximo de 100\% e mínimo absoluto de $91,85 \%$.

Pleopeltis hirsutissima apresentou uma variação maior do CRA do que M.squamulosa. Durante o período úmido P.hirsutissima apresentou um CRA médio de $80,402 \pm 0,746 \%$ com valor máximo igual a $100 \%$ e mínimo de $50,30 \%$. Durante o período seco o CRA médio de P.hirsutissima caiu para $11,940 \pm 0,535 \%$ com máximo de $23,25 \%$ e mínimo de $1,30 \%$, apresentando um contraste ao CRA de M.squamulosa (Figura 11).

O CRA de M.squamulosa não apresentou grande variação quando seus valores foram comparados entre o período úmido e o período seco. Durante o período úmido M.squamulosa apresentou CRA médio de $97,033 \pm 0,140 \%$, com máximo de $100 \%$ e mínimo de $91,85 \%$ e durante o período seco a média do seu CRA apresentou valor igual a 96,609 $\pm 0,208 \%$, com valor máximo de $100 \%$ e mínimo de 91,97\% (Tabela 4).

Tabela 4 - Conteúdo relativo de água (\%) apresentado pelas espécies M.squamulosa e P.hirsutissima durante todo o período amostrado, durante o período seco e úmido. Os valores apresentados na tabela são média, desvio padrão, máximo e mínimo.

\begin{tabular}{lccc}
\hline Espécie & Período todo (\%) & Período seco (\%) & Período úmido (\%) \\
\hline M. squamulosa & $97,00 \pm 1,53$ & $96,609 \pm 0,208$ & $97,033 \pm 0,140$ \\
& $($ de 91,85 a 100) & (de 91,97 a 100) & $($ de 91,85 a 100) \\
P. hirsutissima & $62,875 \pm 30,860$ & $11,940 \pm 0,535$ & $80,402 \pm 0,746$ \\
& $($ de 1,30 a 100$)$ & $($ de 1,30 a 23,25$)$ & $($ de 50,30 a 99,16$)$ \\
\hline
\end{tabular}




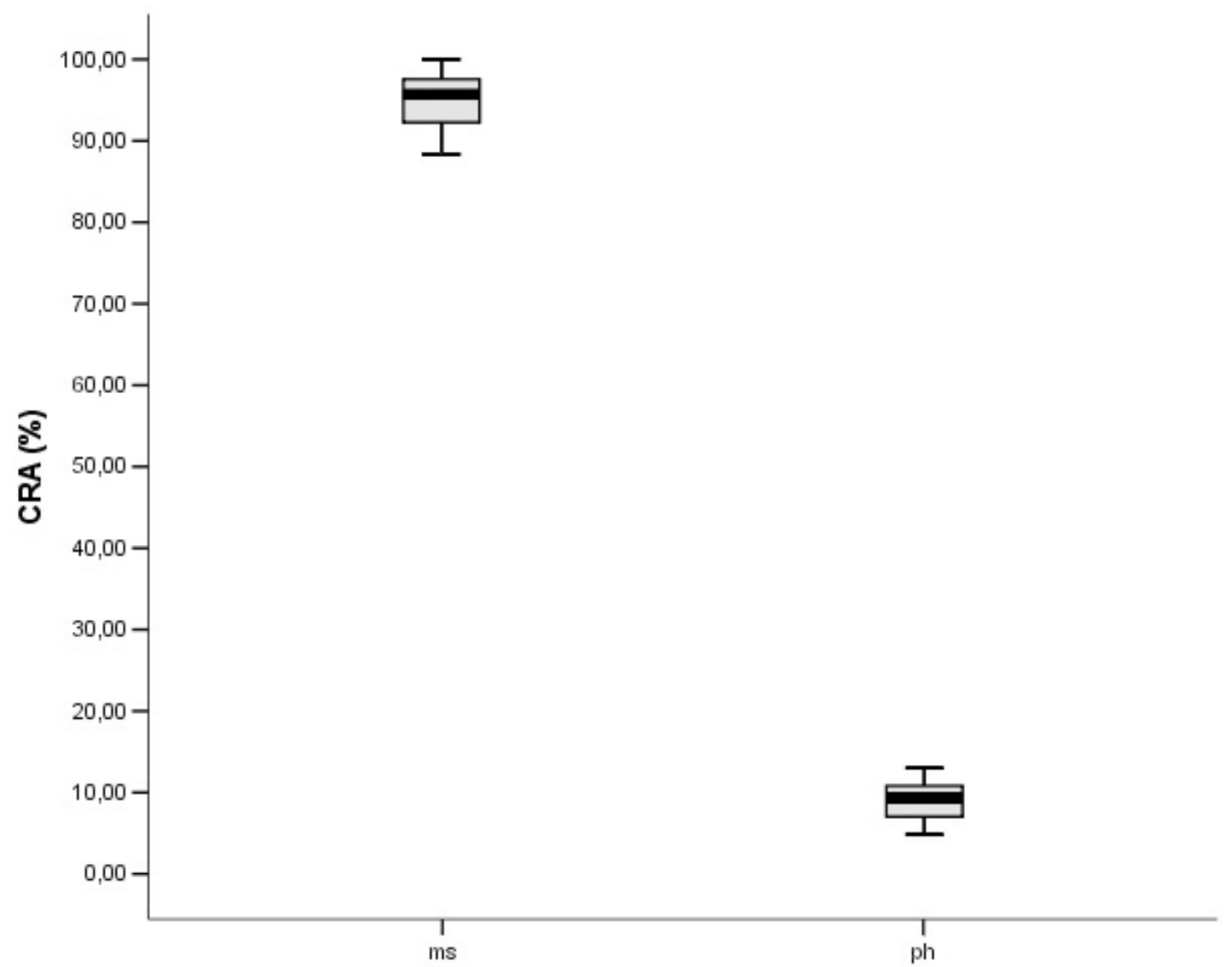

Figura 11 - Boxplot representando o conteúdo relativo de água (CRA) (\%) das espécies Microgramma squamulosa (ms) e Pleopeltis hirsutissima (ph) no final do mês mais seco amostrado (Agosto/2010 com 3,7mm de precipitação total).

Através da análise de mistura da frequência obtida para o CRA, foi possível distinguir dois subgrupos ou estados fisiológicos em M.squamulosa (Figura 12) e dois subgrupos em P.hirsutissima (Figura 13). Em M.squamulosa o primeiro subgrupo apresentou uma média de $97,027 \pm 1,423 \%$ (probabilidade de ocorrência 0,890 ) e o segundo apresentou uma média de 80,779 $\pm 20,470 \%$ (probabilidade de ocorrência 0,110). Em P.hirsutissima o primeiro subgrupo apresentou média igual a 79,530 $10,390 \%$ (probabilidade de ocorrência 0,719 ) e o segundo subgrupo apresentou média igual a $12,702 \pm 6,260 \%$ (probabilidade de ocorrência 0,280). 


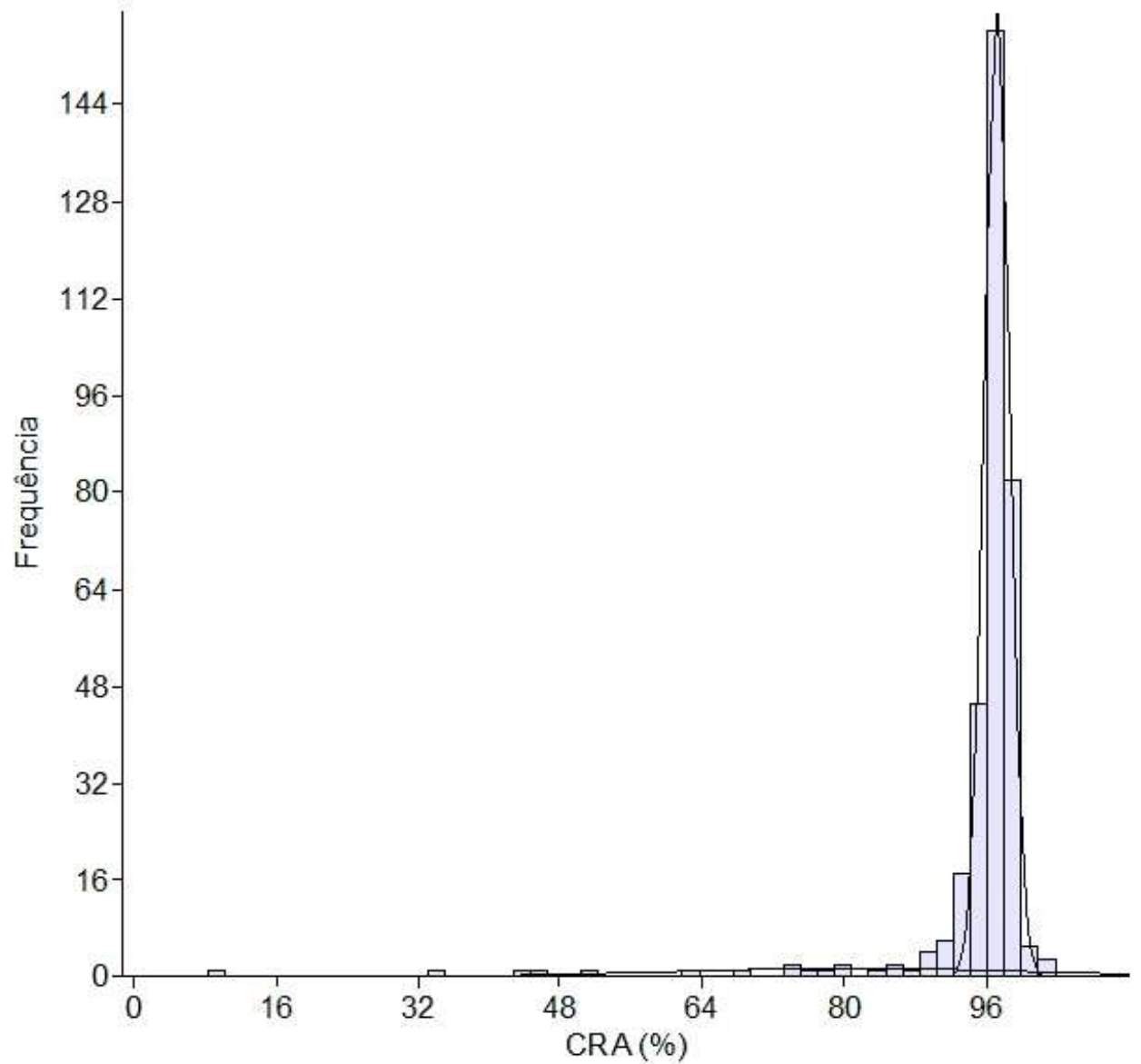

Figura 12 - Histograma de frequência resultante da análise de mistura do conteúdo relativo de água (CRA) (\%) em Microgramma squamulosa durante todo o período de coleta. A primeira subpopulação apresentou uma média de $97,027 \pm 1,423 \%$ e probabilidade de ocorrência 0,890 (à direita) e a segunda de $80,779 \pm 20,47 \%$ e a probabilidade de ocorrência 0,110 (à esquerda). Para esse ajuste o valor de Log I.hood foi de -473 e de Akaike IC 954,7. 


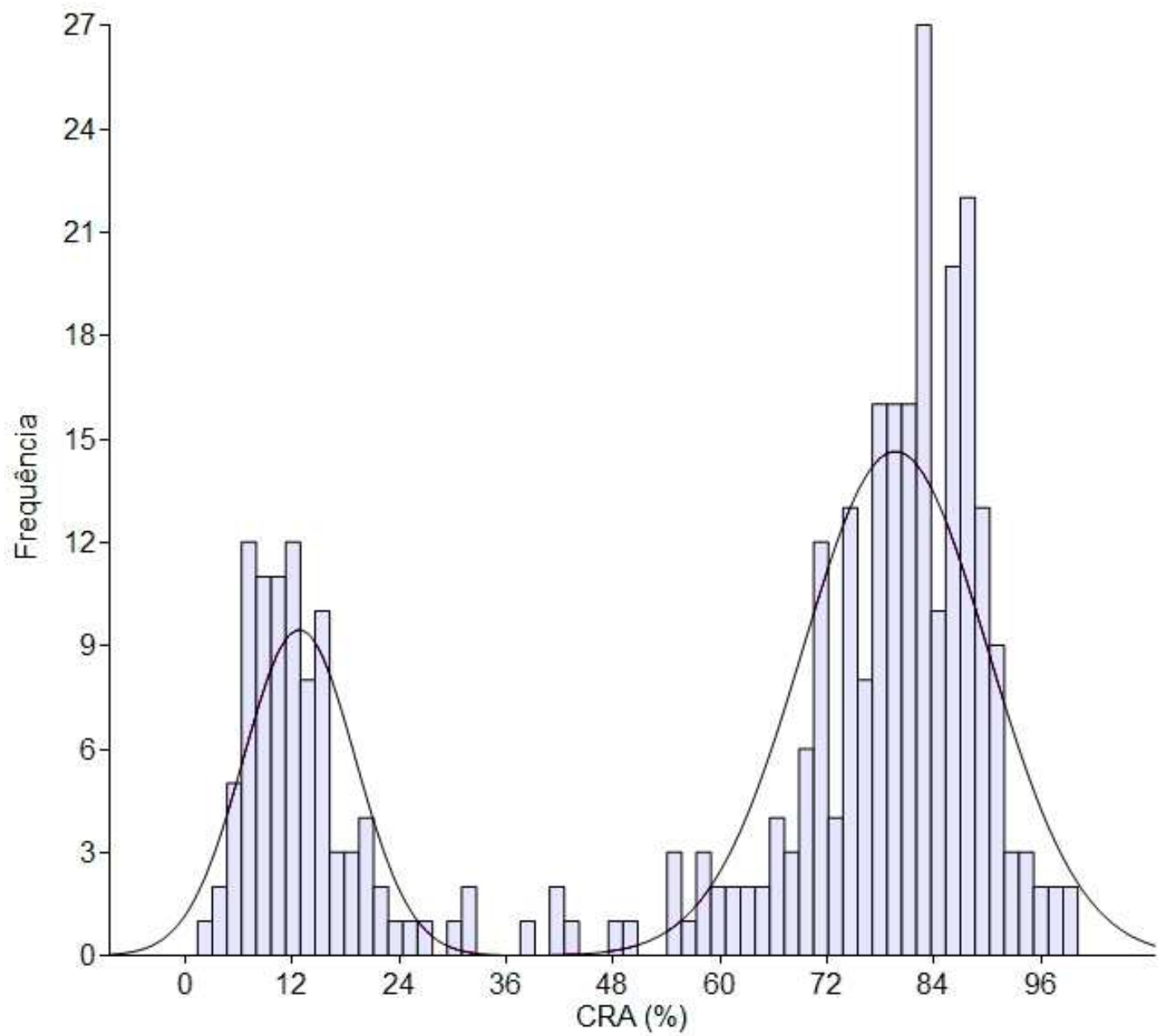

Figura 13 - Histograma de frequência resultante da análise de mistura do conteúdo relativo de água (CRA) (\%) em Pleopeltis hirsutissima durante todo o período de coleta. A primeira subpopulação apresentou média 79,53 \pm $10,390 \%$ e probabilidade de ocorrência 0,719 (à direita), a segunda 12,702 \pm 6,26 e probabilidade de ocorrência 0,280 (à esquerda). Para esse ajuste o valor de Log I.hood foi de -1059 e de Akaike IC 2127. 


\subsubsection{Rendimento quântico máximo aparente do PSII}

Durante todo o período amostrado, P.hirsutissima apresentou uma ampla variação em seus valores de $\mathrm{Fv} / \mathrm{Fm}$, obtendo uma média igual a 0,637 $\pm 0,268$, com valor máximo de 0,85 e mínimo de 0,02. Em contraste, o $\mathrm{Fv} / \mathrm{Fm}$ nos indivíduos de M.squamulosa apresentou pouca variação, obtendo uma média igual a 0,796 $\pm 0,029$, com máximo de 0,89 e mínimo de 0,69.

Os valores de $\mathrm{Fv} / \mathrm{Fm}$ em P.hirsutissima apresentaram uma grande queda do período úmido para o seco, obtendo uma média igual a $0,800 \pm 0,0346$ $(n=68)$ e $0,2890 \pm 0,294 \quad(n=70)$, respectivamente $(p<0,01)$. M.squamulosa também apresentou uma queda significativa, porém menor do que em P.hirsutissima do período úmido para o seco, apresentando valor de $\mathrm{Fv} / \mathrm{Fm}$

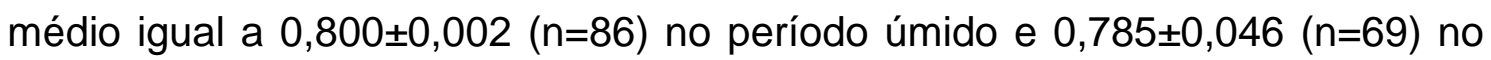
período seco $(p<0,01)$ (Tabela 5 , Figura 14).

Tabela 5 - Rendimento quântico máximo aparente do PSII (Fv/Fm) apresentado pelas espécies M.squamulosa e P.hirsutissima durante todo o período amostrado, durante o período seco e úmido. Os valores apresentados na tabela são média, desvio padrão, máximo e mínimo.

\begin{tabular}{lccc}
\hline Espécie & Período todo & Período seco & Período úmido \\
\hline M. squamulosa & $\begin{array}{c}0,796 \pm 0,029 \\
(\text { de } 0,69 \text { a } 0,89)\end{array}$ & $\begin{array}{c}0,785 \pm 0,046 \\
\text { (de } 0,68 \text { a } 0,84)\end{array}$ & $\begin{array}{c}0,800 \pm 0,002 \\
(\text { de } 0,75 \text { a } 0,84)\end{array}$ \\
P. hirsutissima & $\begin{array}{c}0,637 \pm 0,268 \\
(\text { de } 0,02 \text { a } 0,85)\end{array}$ & $\begin{array}{c}0,289 \pm 0,294 \\
\text { (de } 0,02 \text { a } 0,83)\end{array}$ & $\begin{array}{c}0,800 \pm 0,0346 \\
(\text { de } 0,72 \text { a } 0,84)\end{array}$ \\
\hline
\end{tabular}




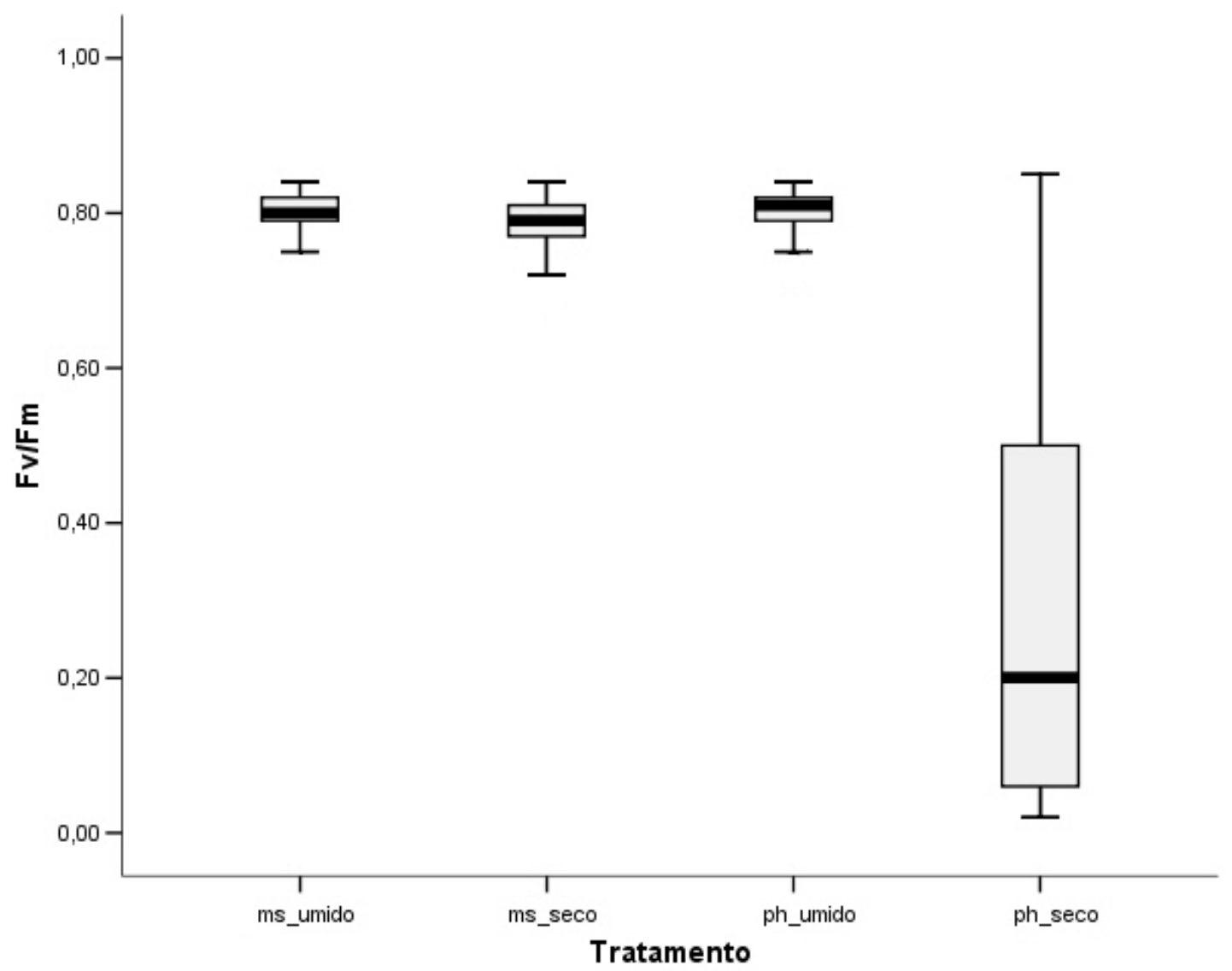

Figura 14 - Boxplot representando o rendimento quântico máximo aparente do PSII (Fm/Fm) das espécies Microgramma squamulosa (ms) e Pleopeltis hirsutissima (ph) durante o período úmido e no período seco.

A análise de misturas para os valores de $\mathrm{Fv} / \mathrm{Fm}$ permite sugerir a existência de dois subgrupos para M.squamulosa (Figura 15) e P.hirsutissima (Figura 16). Em M.squamulosa o primeiro subgrupo apresentou uma média de 0,799 $\pm 0,024$ (probabilidade de ocorrência 0,936) e o segundo apresentou média de 0,593 $\pm 0,242$ (probabilidade de ocorrência 0,0635). Em P.hirsutissima o primeiro subgrupo apresentou média de 0,812 $\pm 0,017$ (probabilidade de ocorrência 0,609 ) e o segundo subgrupo apresentou média de $0,364 \pm 0,246$ (probabilidade de ocorrência 0,390). 


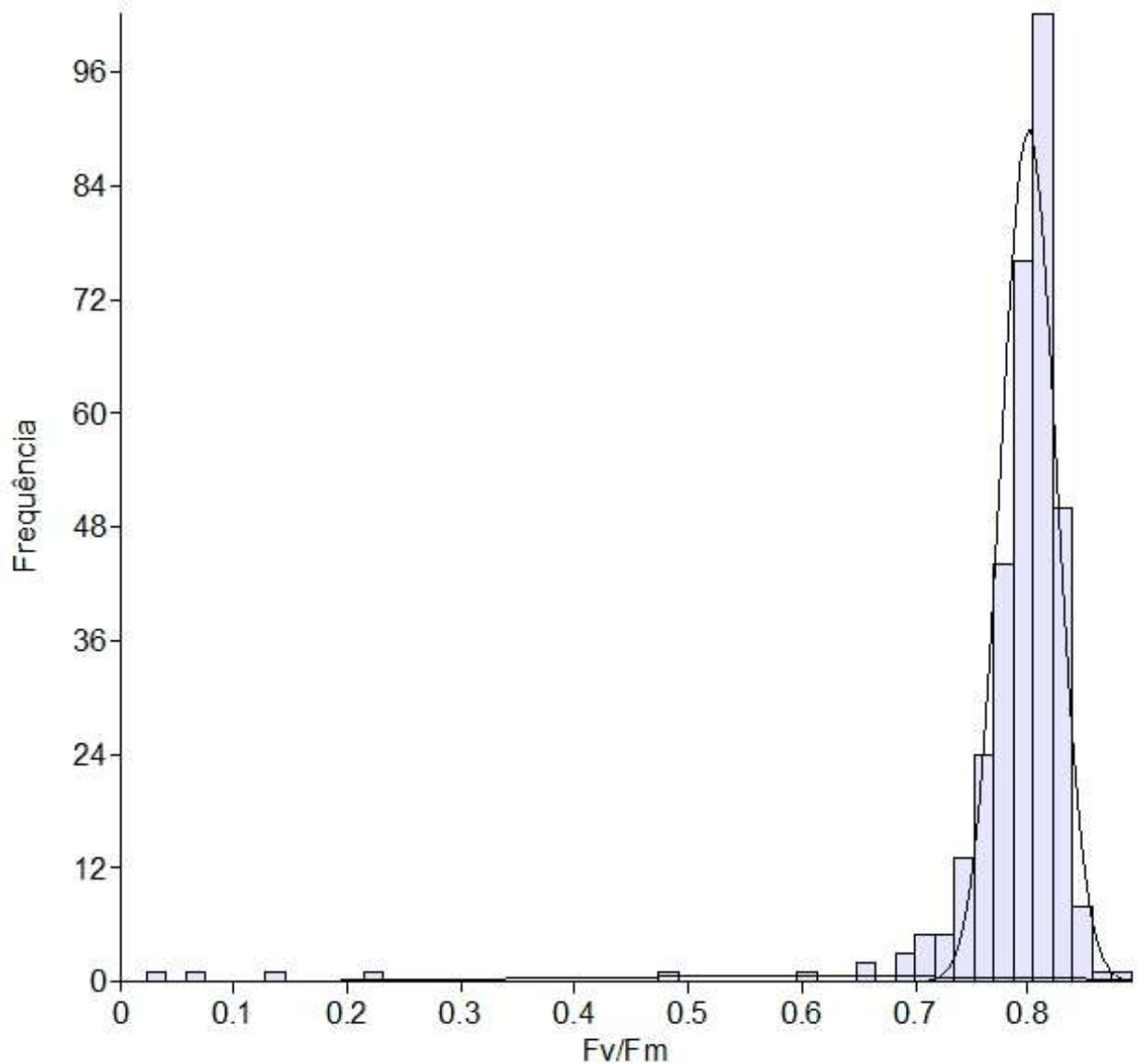

Figura 15 - Histograma de frequência resultante da análise de mistura do rendimento quântico máximo aparente do PSII (Fv/Fm) de Microgramma squamulosa durante todo o período de coleta. A primeira subpopulação apresentou uma média de $0,799 \pm 0,0245$ e probabilidade de ocorrência 0,936 (à direita) e a segunda de 0,59353 $\pm 0,24206$ e probabilidade de ocorrência 0,0635 (à esquerda). Para esse ajuste o valor de Log I.hood foi de 982,8 e de Akaike IC -1957 


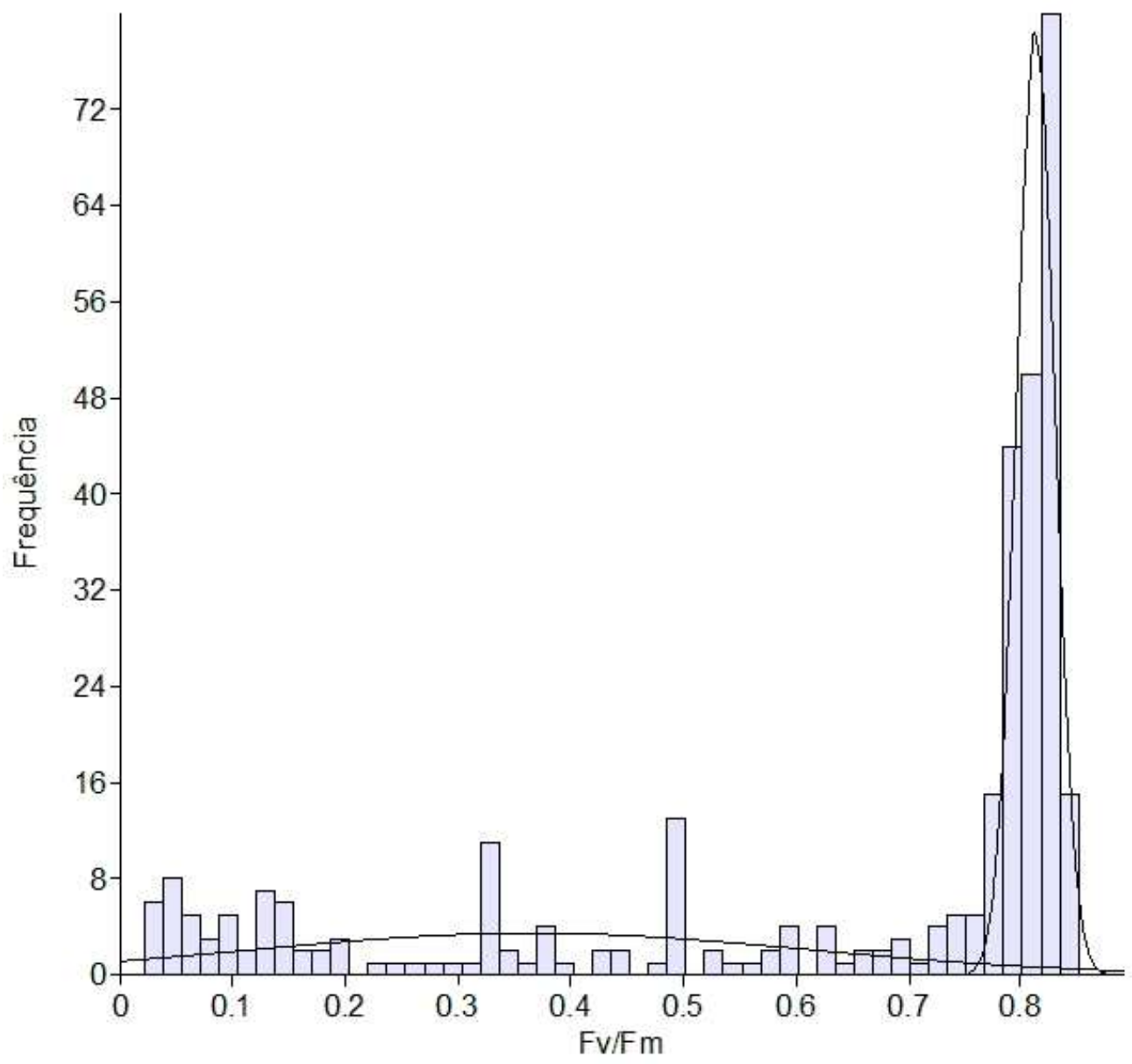

Figura 16 - Histograma de frequência resultante da análise de mistura do rendimento quântico máximo aparente do PSII (Fv/Fm) em Pleopeltis hirsutissima durante todo o período de coleta. A primeira subpopulação apresentou média de $0,812 \pm 0,017$ e probabilidade de ocorrência 0,609 (à direita) e a segunda subpopulação apresentou média de $0,364 \pm 0,246$ e probabilidade de ocorrência 0,390 (à esquerda). Para esse ajuste o valor de Log I.hood foi de 640 e de Akaike IC -1262.

Do período úmido para o período seco P.hirsutissima apresentou uma queda de seu valor de Fo, apresentando um valor igual a 0,072 $\pm 0,029$ durante o período úmido e $0,056 \pm 0,057$ durante o período seco $(p=0,039)$. Do período úmido para o seco M.squamulosa apresentou uma tendência de aumento em seu valor de Fo. Durante o período úmido M.squamulosa apresentou valor médio de Fo igual a $0,084 \pm 0,010$ e no seco $0,092 \pm 0,062$, porém a diferença não foi significativa $(p=0,332)$. M.squamulosa apresentou um valor de Fo superior a P.hirsutissima durante o período seco $(\mathrm{U}=1616.500, \mathrm{~W}=4171.500$, $\mathrm{p}<0,01$ ) (Figura 17). 


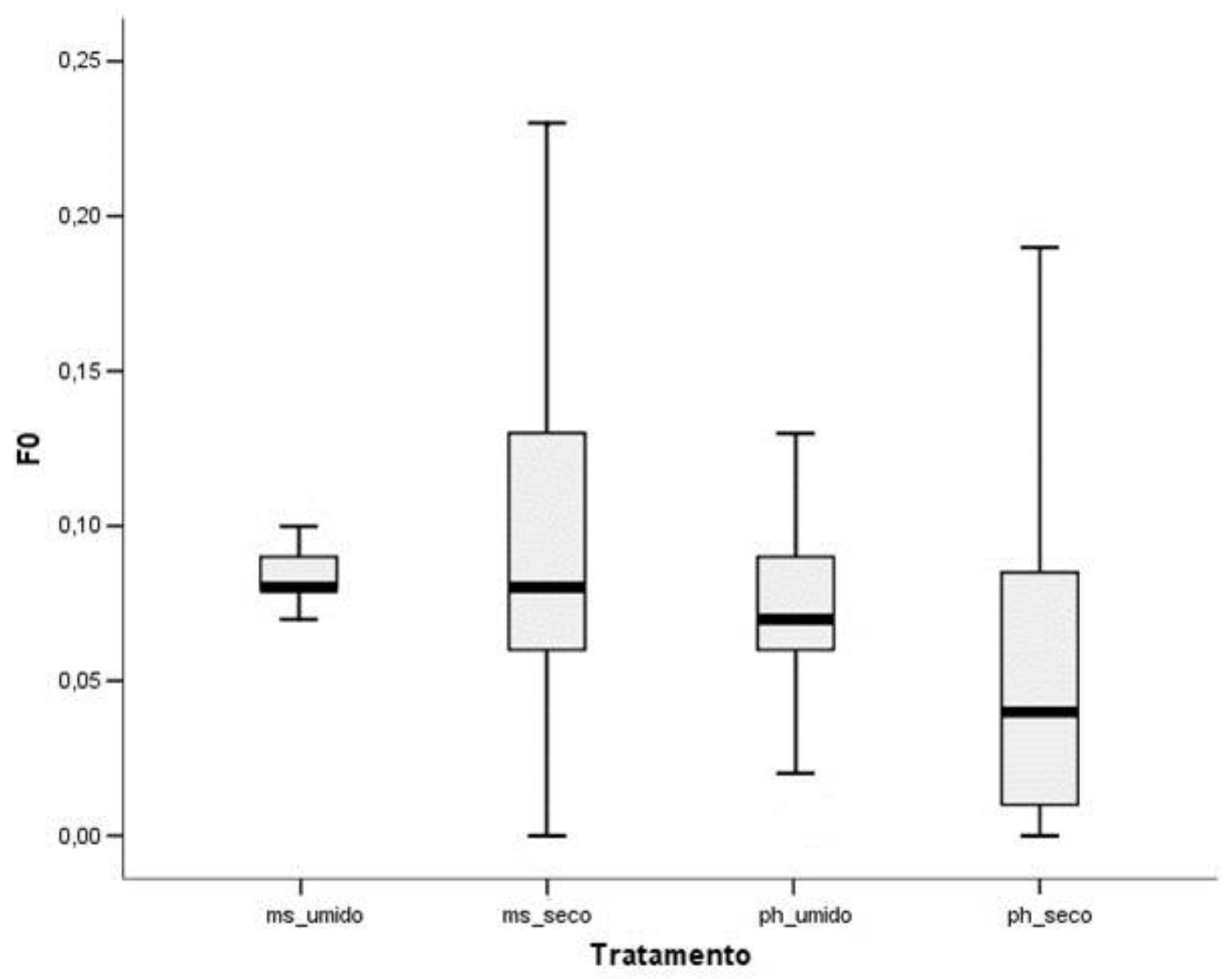

Figura 17 - Boxplot representando a fluorescência inicial (Fo) das espécies Microgramma squamulosa (ms) e Pleopeltis hirsutissima (ph) durante o período úmido e no período seco.

Do período úmido para o seco os valores de $\mathrm{Fm}$ em P.hirsutissima apresentaram queda, obtendo média igual a 0,305 $\pm 0,152(n=88)$ durante 0 período úmido e 0,048 $\pm 0,058(n=77)$ no período seco $(p<0,01)$. Em contraste M.squamulosa não apresentou diferença significativa de seus valores de $\mathrm{Fm}$ quando comparado entre o período úmido e seco, apresentando médias igual a $0,422 \pm 0,088$ e $0,400 \pm 0,274$, respectivamente ( $p=0,956)$ (Figura 18). 


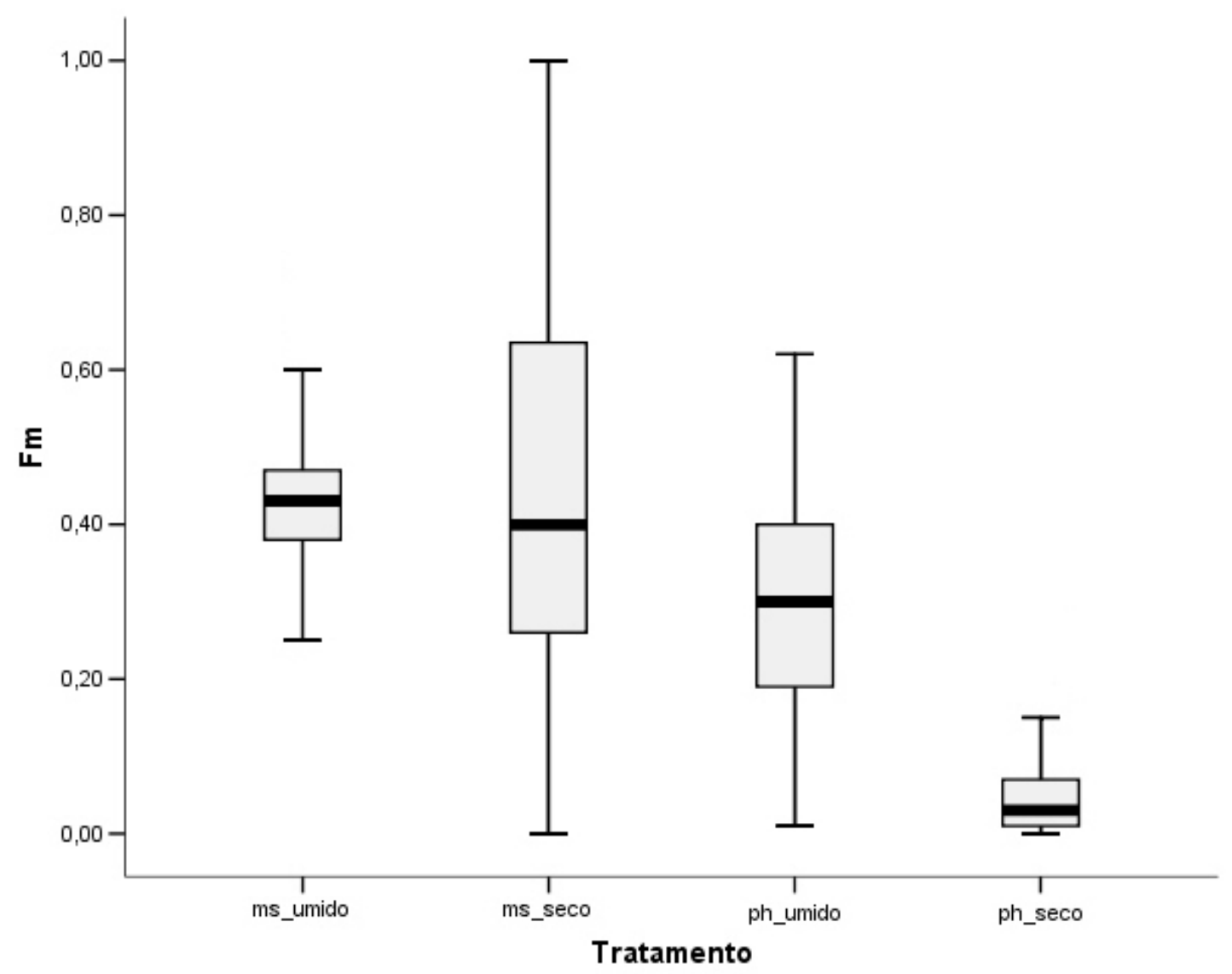

Figura 18 - Boxplot representando a fluorescência máxima $(\mathrm{Fm})$ das espécies Microgramma squamulosa (ms) e Pleopeltis hirsutissima (ph) durante o período úmido e no período seco.

\subsubsection{Rendimento quântico efetivo do PSII}

Do período úmido para o seco P.hirsutissima apresentou uma grande queda de seus valores de $\mathrm{Fv}^{\prime} / \mathrm{Fm}^{\prime}$, obtendo um valor médio de 0,198 $\pm 0,158$ $(\mathrm{n}=122)$ durante o período úmido e igual a $0(n=54)$ durante o período seco, não apresentando diferenças entre os valores de Fs e Fm'. M.squamulosa apresentou uma queda significativa do período úmido para o seco $(p<0,01)$, obtendo valor médio de $\mathrm{Fv}^{\prime} / \mathrm{Fm}^{\prime}$ igual a $0,134 \pm 0,093 \quad(\mathrm{n}=117)$ e $0,087 \pm 0,07$ $(n=67)$, respectivamente, mantendo seus aceptores abertos mesmo durante 0 período seco (Figura 19). Durante o período úmido P.hirsutissima apresentou um rendimento quântico efetivo do PSII ( $\mathrm{Fv}^{\prime} / \mathrm{Fm}^{\prime}$ ) mais elevado do que M.squamulosa $(\mathrm{U}=5468.500, \mathrm{~W}=12371.500$, bicaudal, $\mathrm{p}=0,002)$. 


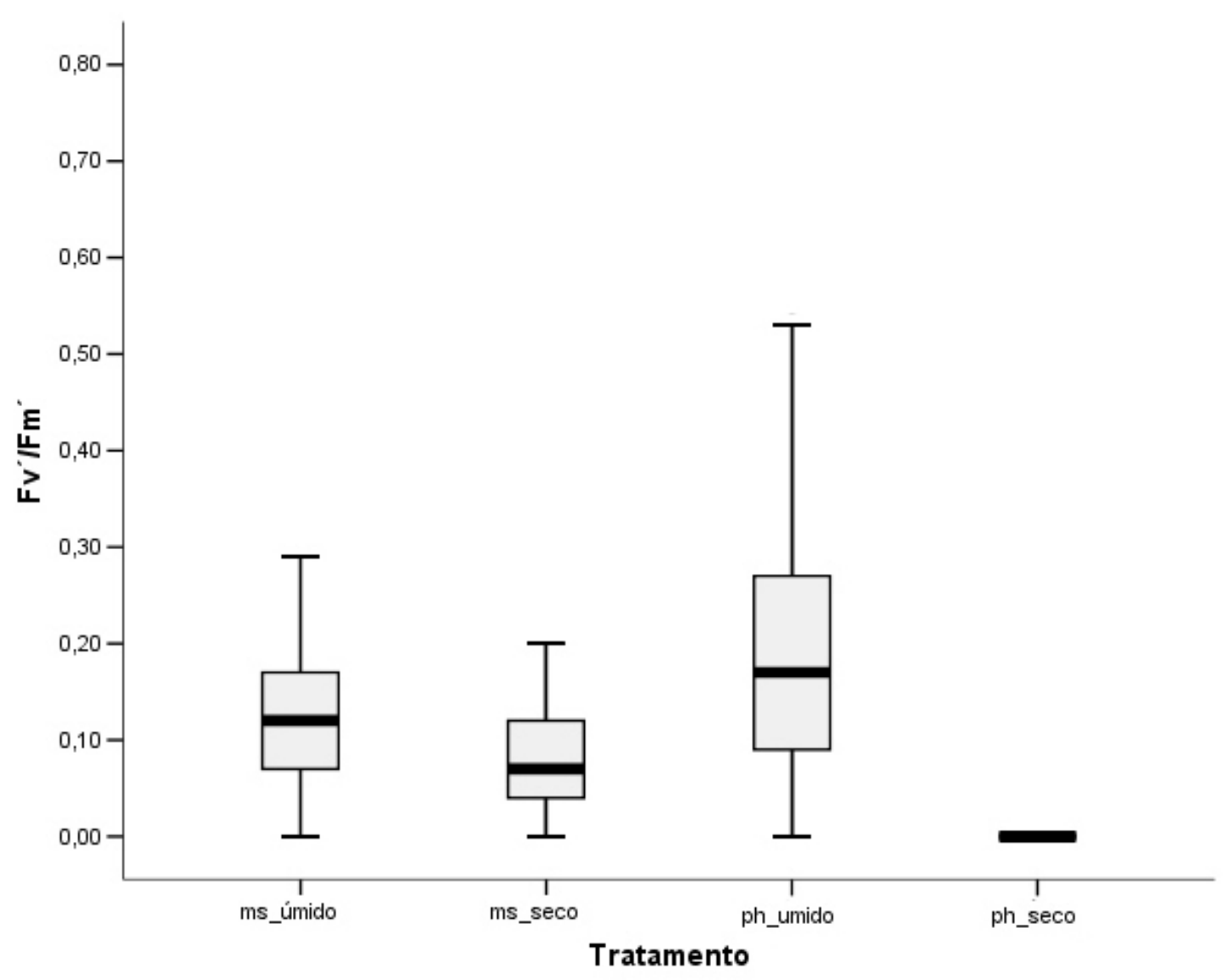

Figura 19 - Boxplot representando o rendimento quântico efetivo do fotossistema II (Fv'/Fm') das espécies Microgramma squamulosa (ms) e Pleopeltis hirsutissima (ph) durante o período úmido e no período seco.

\subsubsection{Taxa de transferência de elétrons}

Durante todo o período amostrado, P.hirsutissima obteve uma média de ETR igual a $24,394 \pm 1,602 \mu \mathrm{mol} \mathrm{m} \mathrm{m}^{-2} \mathrm{~s}^{-1}(\mathrm{n}=126)$, com máximo de 84,29 e mínimo de $0 \mu \mathrm{mol} \mathrm{m} \mathrm{m}^{-2} \mathrm{~s}^{-1}$ e M.squamulosa obteve uma média de $16,906 \pm 0,998 \mu \mathrm{mol} \mathrm{m}$ ${ }^{2} \mathrm{~s}^{-1}(\mathrm{n}=127)$, com máximo de 52,920 $\mu \mathrm{mo} \mathrm{m}^{-2} \mathrm{~s}^{-1}$ e mínimo de $0 \mu \mathrm{mol} \mathrm{m}^{-2} \mathrm{~s}^{-1}$.

Da mesma forma que o $\mathrm{Fv}^{\prime} / \mathrm{Fm}^{\prime}$, os valores de ETR apresentaram queda do período úmido para o seco. P.hirsutissima apresentou uma média igual a $24,40 \pm 18,00 \mu \mathrm{mol} \mathrm{m} \mathrm{m}^{-2} \mathrm{~s}^{-1}(\mathrm{n}=126)$ e $0,00 \mu \mathrm{mol} \mathrm{m} \mathrm{m}^{-2} \mathrm{~s}^{-1}(\mathrm{n}=47) \quad(\mathrm{p}<0,01)$. M.squamulosa também apresentou queda de seus valores, obtendo média de $16,910 \pm 11,250$ durante o período úmido e 11,09 $\pm 11,32$ durante o período seco $(p<0,01)$. Durante o período úmido P.hirsutissima apresentou ETR mais elevado do que M.squamulosa ( $U=5920.00, W=14048.00$, bicaudal, $p<0,01)$. 


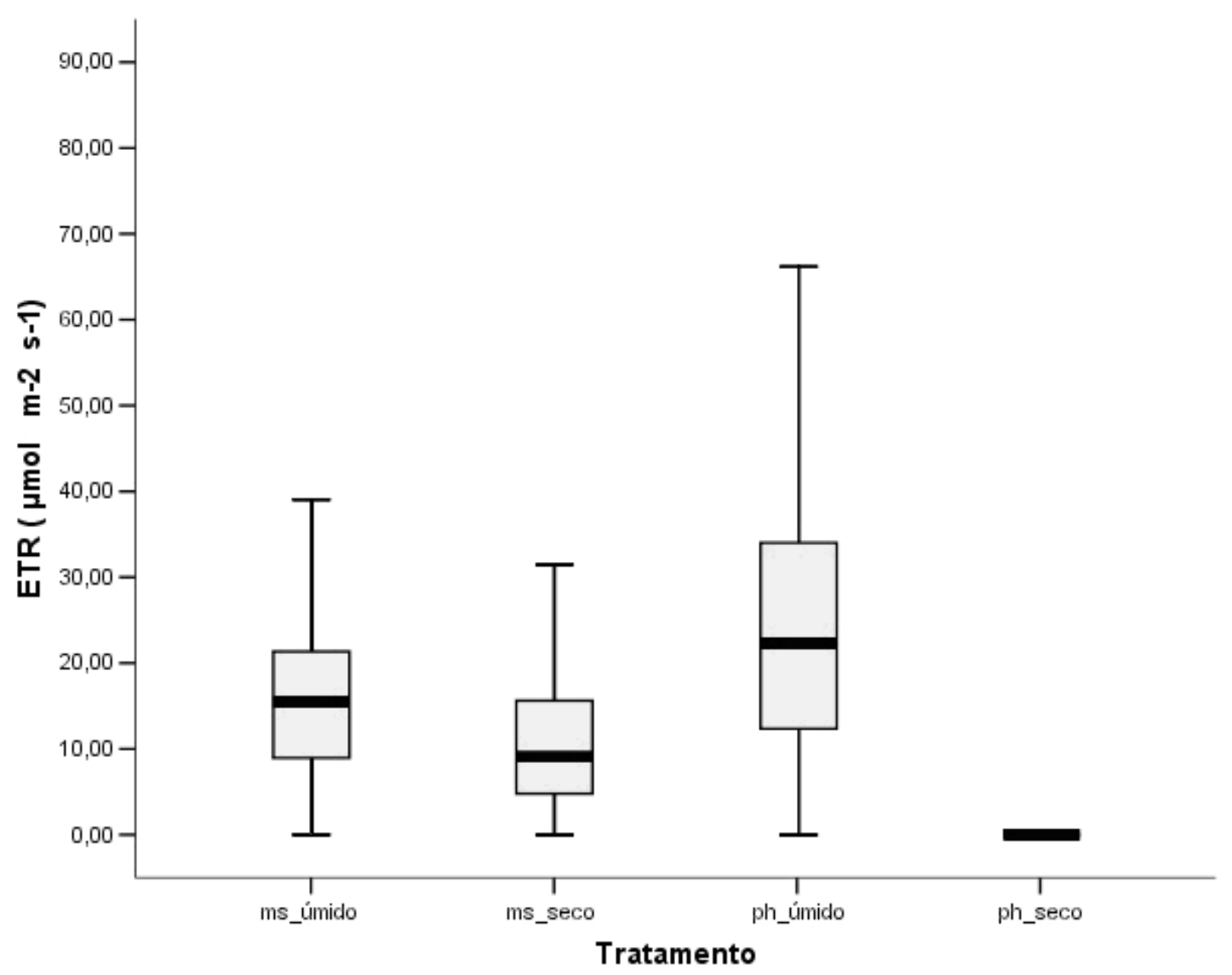

Figura 20 - Boxplot representando a taxa de transferência de elétrons (ETR) $\left(\mu \mathrm{mols} \mathrm{m}^{-2} \mathrm{~s}^{-1}\right.$ ) em Microgramma squamulosa (ms) e Pleopeltis hirsutissima (ph) durante o período úmido e o período seco.

\subsubsection{Eficiência do uso da água}

A eficiência do uso da água (EUA) em M.squamulosa se manteve estável e foi superior a EUA de P.hirsutissima durante o período úmido e seco. Durante o período úmido a eficiência do uso da água em M.squamulosa apresentou uma média de $13,41 \pm 1,09 \mu \mathrm{mol} \mathrm{mmol}^{-1}(\mathrm{n}=140)$ com máximo de $67,69 \mu \mathrm{mol} \mathrm{mmol}{ }^{-1}$ e mínimo de $0,55 \mu \mathrm{mol} \mathrm{mmol}^{-1}$. Durante o período seco a EUA em M.squamulosa foi superior ao do período úmido, obtendo uma média de $15,538 \pm 2,299 \mu \mathrm{mol} \mathrm{mmol}^{-1}(\mathrm{n}=56)$, com máximo de 76,670 $\mathrm{mol} \mathrm{mmol}^{-1} \mathrm{e}$ mínimo de $0,380 \mu \mathrm{mol} \mathrm{mmol}^{-1}$.

Ao contrário de M.squamulosa, $P$. hirsutissima apresentou uma queda na sua eficiência de uso da água durante o período seco. Durante o período úmido P.hirsutissima apresentou uma média de $8,860 \pm 0,635 \mu \mathrm{mol} \mathrm{mmol}^{-}$ ${ }^{1}(\mathrm{n}=126)$, com máximo de 34,23 e mínimo de $0,31 \mu \mathrm{mol} \mathrm{mmol}^{-1}$ e durante o 
período seco a média foi igual a $3,68 \pm 1,103 \mu \mathrm{mol} \mathrm{mmol}^{-1}(\mathrm{n}=17)$, com máximo de 15,33 e mínimo de 0,34 $\mu \mathrm{mol} \mathrm{mmol}^{-1}$ (Figura 21).

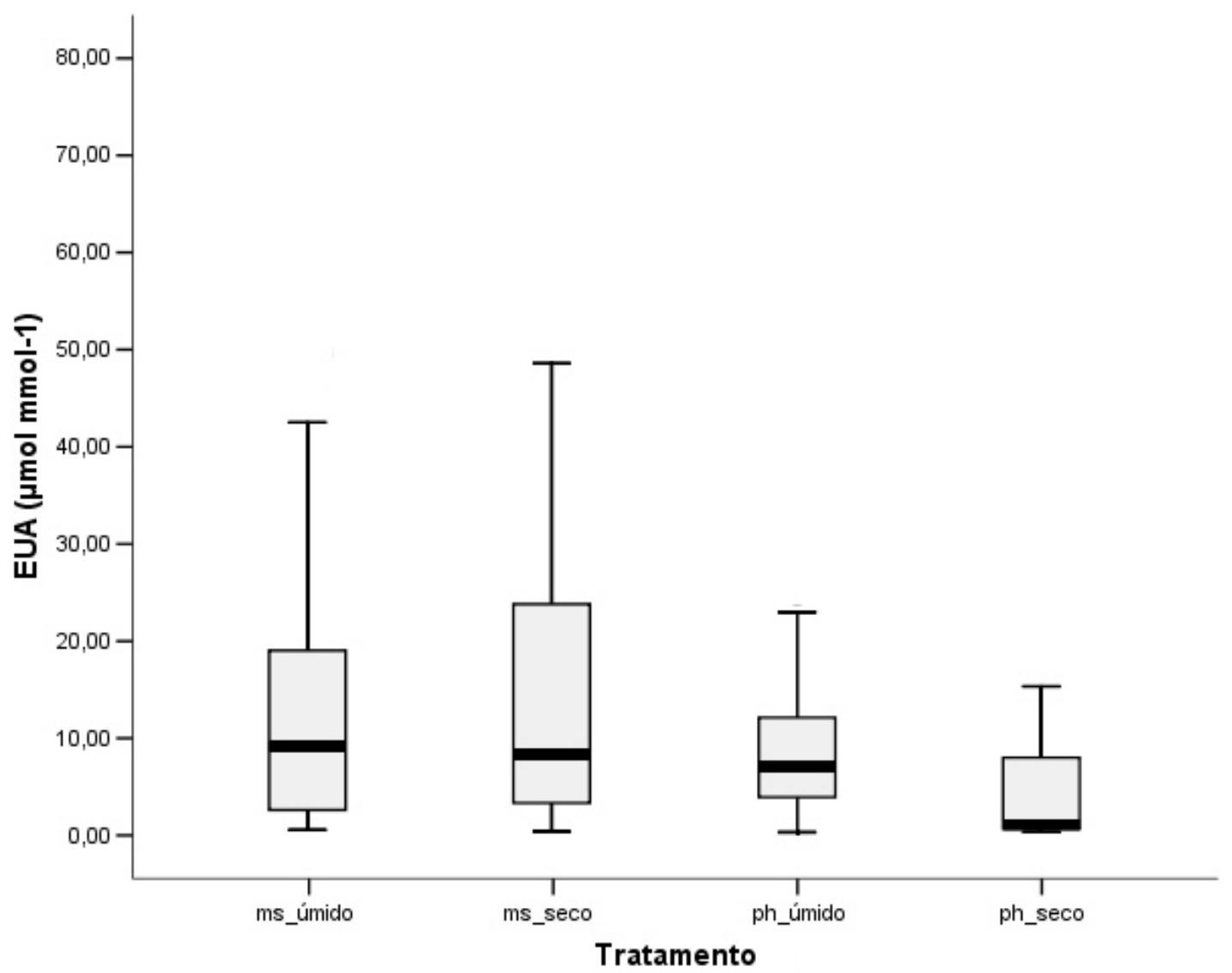

Figura 21 - Boxplot representando a eficiência de uso da água (EUA) ( $\mu \mathrm{mol}$ mmol-1) em Microgramma squamulosa (ms) e Pleopeltis hirsutissima (ph) durante o período seco.

\subsubsection{Condutância estomática}

De forma geral P.hirsutissima apresentou uma condutância estomática superior a condutância apresentada por M.squamulosa (Figura 23). Durante o período úmido P.hirsutissima apresentou um valor máximo da condutância estomática mais elevada do que M.squamulosa. (Figura 23) P.hirsutissima apresentou valor mínimo de $0 \mathrm{mmol} \mathrm{m}^{-2} \mathrm{~s}^{-1}$ e máximo de $31,00 \mathrm{mmol} \mathrm{m}^{-2} \mathrm{~s}^{-1} \mathrm{e}$ M.squamulosa apresentou mínimo de $0 \mathrm{mmol} \mathrm{m}^{-2} \mathrm{~s}^{-1}$ e máximo de $22,20 \mathrm{mmol} \mathrm{m}^{-2} \mathrm{~s}^{-1}$. Porém a diferença apresentada não foi significativa $(U=9434.500, W=196721.500$, bicaudal, $p=0,444, n=150$ (ph), $n=143(m s)$ ).

Durante o período seco P.hirsutissima não apresentou condutância estomática, apresentando uma frequência de zeros $(88,84 \%)$, superior a de 
M. squamulosa (65\%) (Figura 22). Nesse período P.hirsutissima obteve um valor mínimo de $0 \mathrm{mmol} \mathrm{m} \mathrm{m}^{-2} \mathrm{~s}^{-1}$ e máximo de $0,01 \mathrm{mmol} \mathrm{m}^{-2} \mathrm{~s}^{-1}$. M.squamulosa também apresentou queda na condutância quando comparada ao período úmido, porém não apresentou o fechamento total dos seus estômatos, obtendo um valor mínimo de $0 \mathrm{mmol} \mathrm{m}^{-2} \mathrm{~s}^{-1}$ e máximo de $4 \mathrm{mmol} \mathrm{m}^{-2} \mathrm{~s}^{-1}(\mathrm{U}=11570, \mathrm{~W}=$ 27323, bicaudal, $p<0,001, n=59(\mathrm{ph}), \mathrm{n}=65(\mathrm{~ms})$ ) (Figura 22).

Durante o período de transição P.hirsutissima apresentou um aumento em sua condutância estomática, obtendo um valor mínimo de $0 \mathrm{mmol} \mathrm{m}^{-2} \mathrm{~s}^{-1} \mathrm{e}$ máximo de $56 \mathrm{mmol} \mathrm{m}^{-2} \mathrm{~s}^{-1}$. M.squamulosa também apresentou um aumento, porém esse foi menor do que em P.hirsutissima, apresentando mínimo de $0 \mathrm{mmol} \mathrm{m} \mathrm{m}^{-2} \mathrm{~s}^{-1}$ e máximo de $36 \mathrm{mmol} \mathrm{m}^{-2} \mathrm{~s}^{-1}$. Desta forma, durante o período de transição $P$.hirsutissima apresentou uma condutância estomática mais elevada do que M.squamulosa $(\mathrm{U}=41457.500, \mathrm{~W}=88735.500, \mathrm{p}=0,013$, bicaudal, $\mathrm{n}$ $=101(\mathrm{ph})$ e $\mathrm{n}=102(\mathrm{~ms}))$.

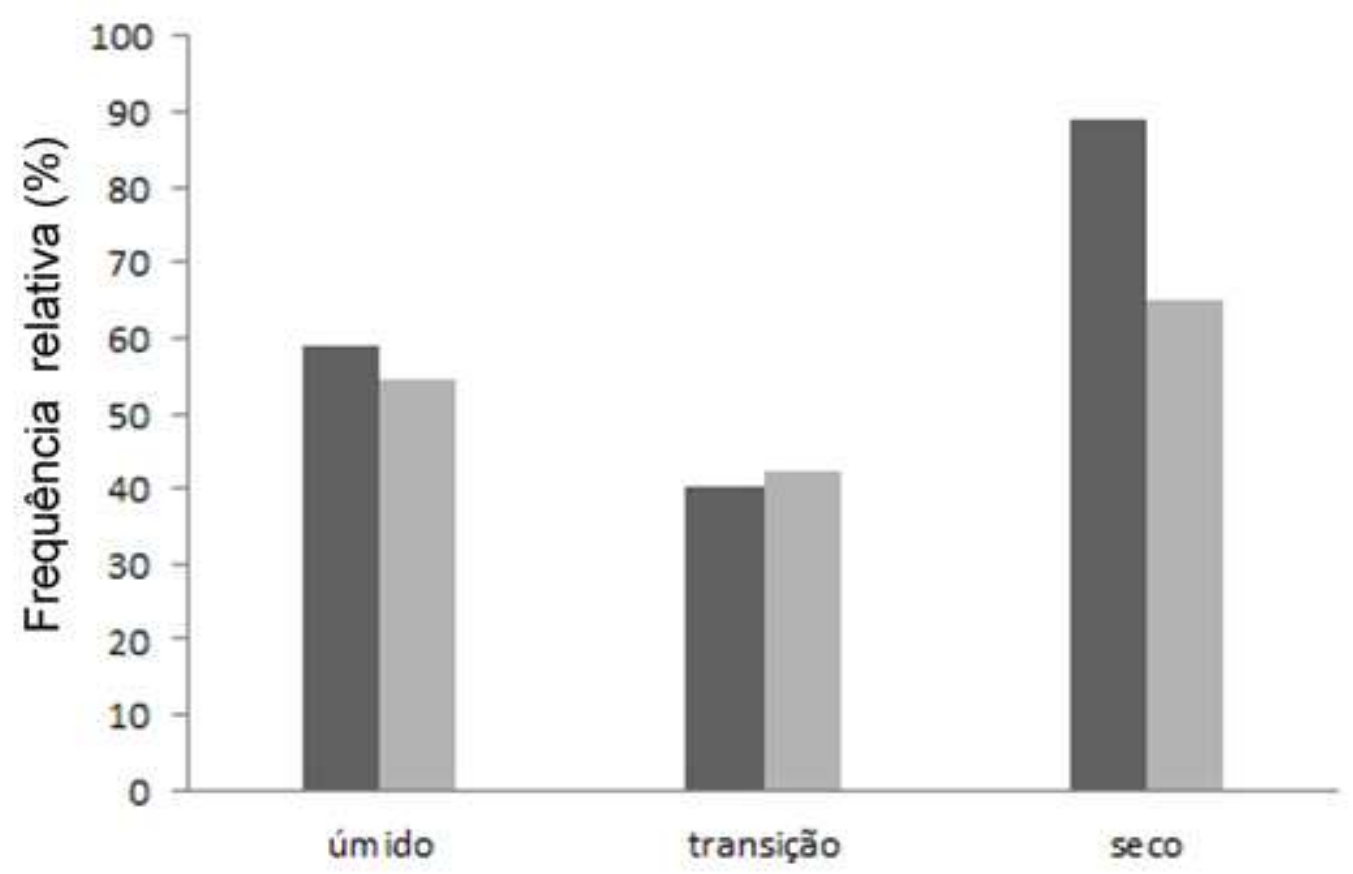

Figura 22 - Frequência relativa de folhas de Pleopeltis hirsutissima (cinza escuro) e Microgramma squamulosa (cinza claro) que apresentaram condutância estomática (mmol.m-2. s-1) igual a zero durante o período úmido, período de transição e o período seco. 

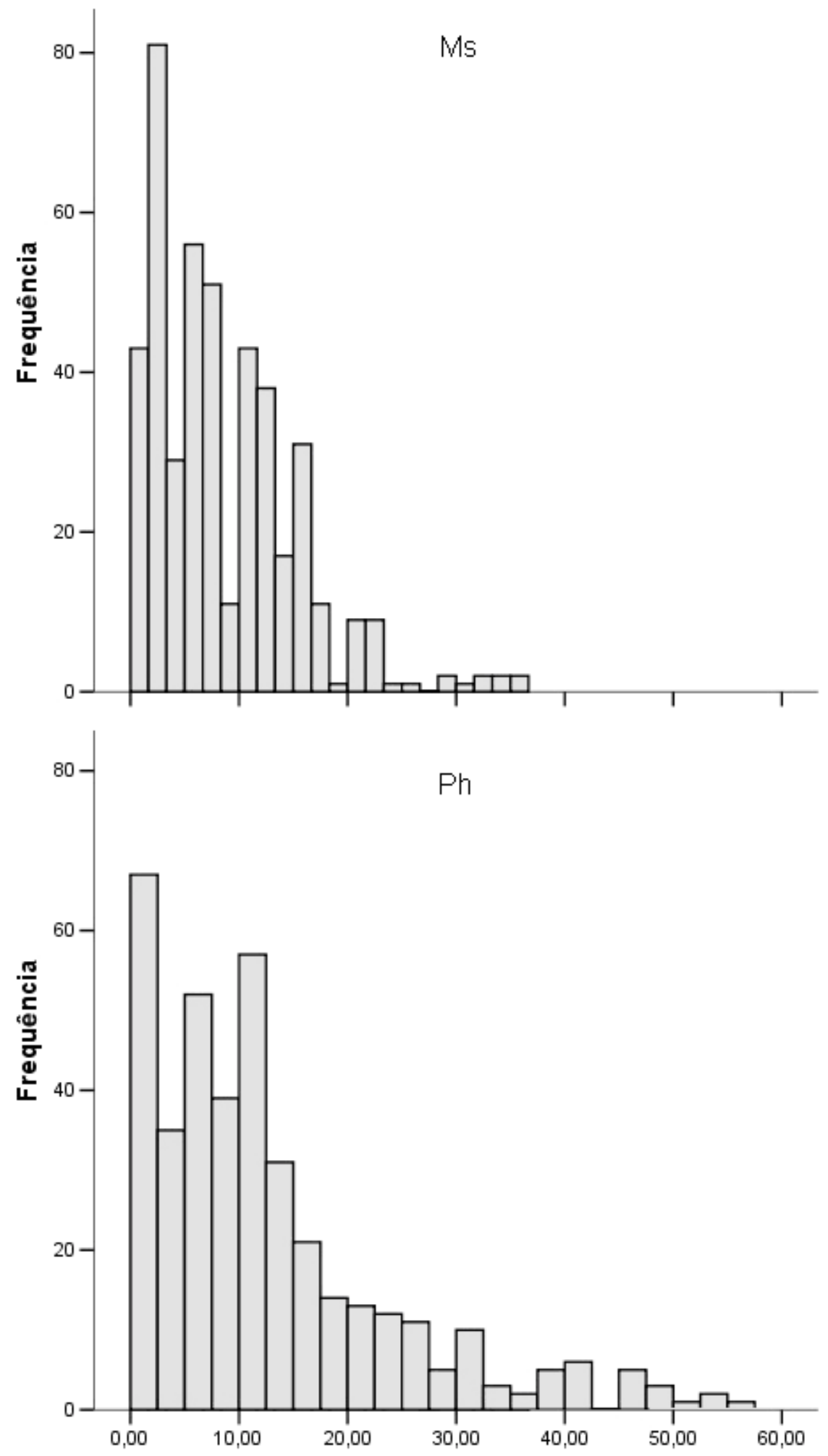

Figura 23 - Frequência da condutância estomática $\left(m m o l . m^{-2} \mathrm{~s}-1\right)$ em folhas de Microgramma squamulosa (média 8,442 $\pm 6,571, \quad n=441$ ) e de Pleopeltis hirsutissima (média 12,490 $\pm 11,442, \mathrm{n}=395$ ) durante o período todo. 


\subsubsection{Regressão Linear}

Em P.hirsutissima os valores de assimilação de carbono apresentaram uma relação positiva com os valores do CRA, se ajustando a função linear com um $R^{2}$ igual 0,586 (Média quadrada $=1584,590, F=1282,902, p<0,001$ ) $(y=0.0414 x-0.4 y 231) \quad$ (Figura 24). A assimilação de carbono também apresentou regressão com os valores de $\mathrm{Fv} / \mathrm{Fm}$ em P.hirsutissima, se ajustando a função linear com $R^{2}$ igual a 0,491 (Média quadrada $=1458,416$, $F=908,41, p<0,001) \quad(y=4.5758 x-0.9408) \quad(F i g u r a 25)$. Os valores de assimilação de $P$.hirsutissima começam a aumentar quando seu potencial de uso da luz fica em torno de 0,6 . Abaixo desse valor $(0,6)$ a assimilação de carbono tende a se manter próximo de zero.

A condutância estomática apresentou uma pequena tendência de correlação positiva com a assimilação, porém o valor foi baixo, apresentando um $R^{2}$ igual a 0,026 (média quadrada 72,500, $F=24,840, p<0,001$ ). Assim com a condutância estomática a taxa de transferência de elétrons não apresentou relação com a assimilação de carbono.

Em folhas de M.squamulosa não foi possível observar relação entre os valores de assimilação de carbono e os valores de CRA, nem entre os valores de assimilação e os valores de $\mathrm{Fv} / \mathrm{Fm}$ e entre a taxa de transferência de elétrons. Somente a condutância estomática apresentou uma correlação positiva com a assimilação de carbono, apresentando $u m R^{2}$ igual a 0,139 (média quadrada 266,931, $F=151,542, p<0,001$ ).

$\mathrm{O}$ valor de $\mathrm{Fv} / \mathrm{Fm}$ em P.hirsutissima apresenta uma relação positiva com - CRA, se ajustando a função logarítmica com $R^{2}$ igual a 0,723 (Média quadrada $=13,972, F=720,289, p<0,001)(y=0.2453 \ln (x)-0.285)$ (Figura 26). Em M.squamulosa essa relação não pode ser observada, uma vez que seu Fv/Fm, e seu CRA sofrem pouca variação, mantendo seus valores próximos a média. 

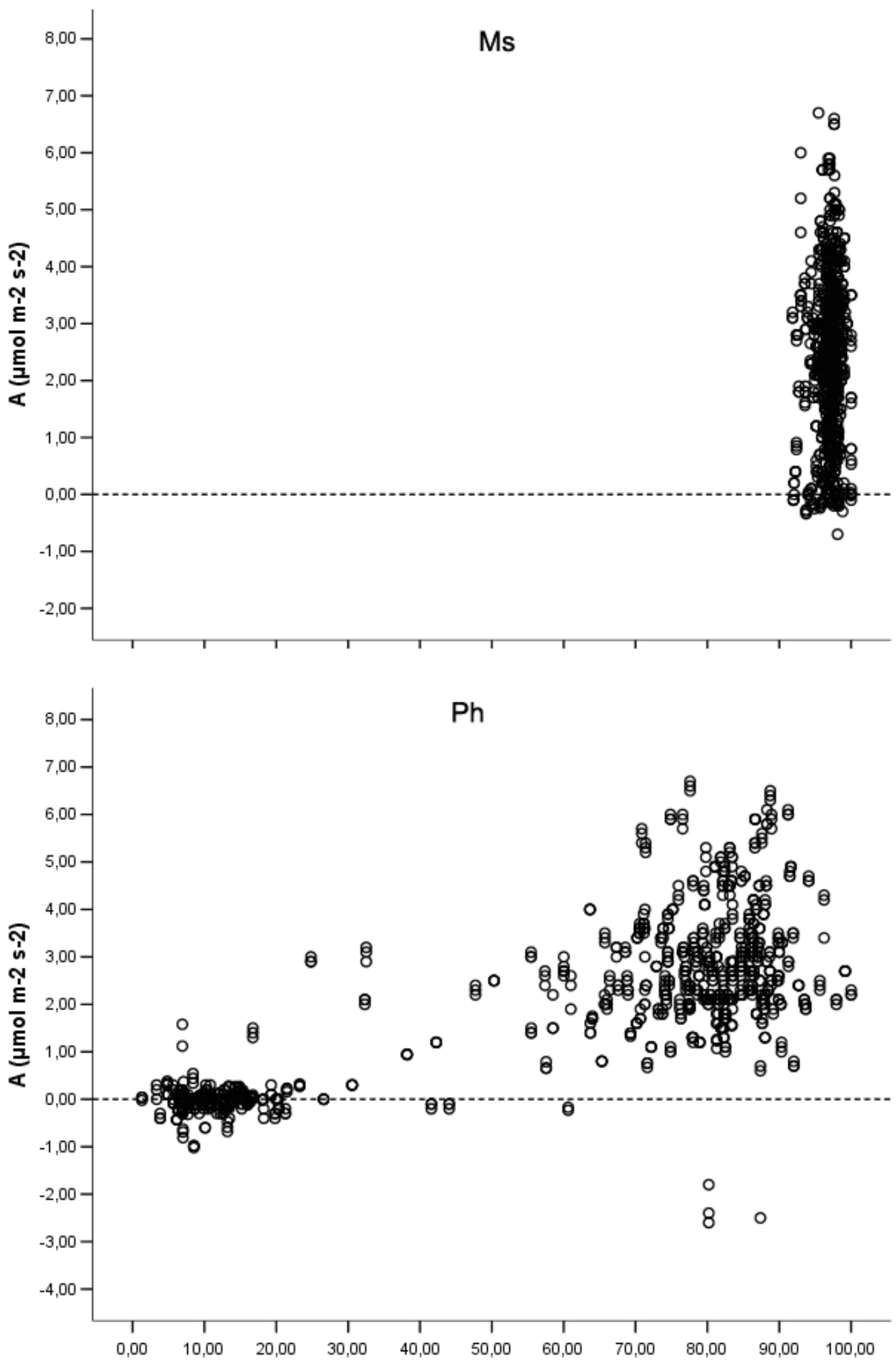

Figura 24 - Gráfico de dispersão representando a relação entre a assimilação líquida

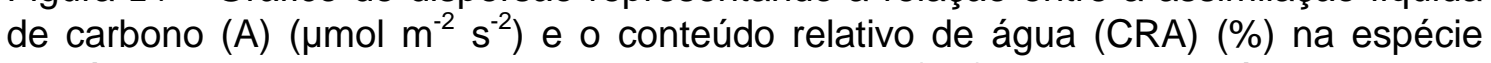
sensível a dessecação Microgramma squamulosa (Ms) e tolerante à dessecação Pleopeltis hirsutissima $(\mathrm{Ph})$ durante todo o período amostrado. A análise de regressão para P.hirsutissima apresentou um valor de $\mathrm{R}^{2}$ igual a 0,586 . Cada círculo representa uma folha. 

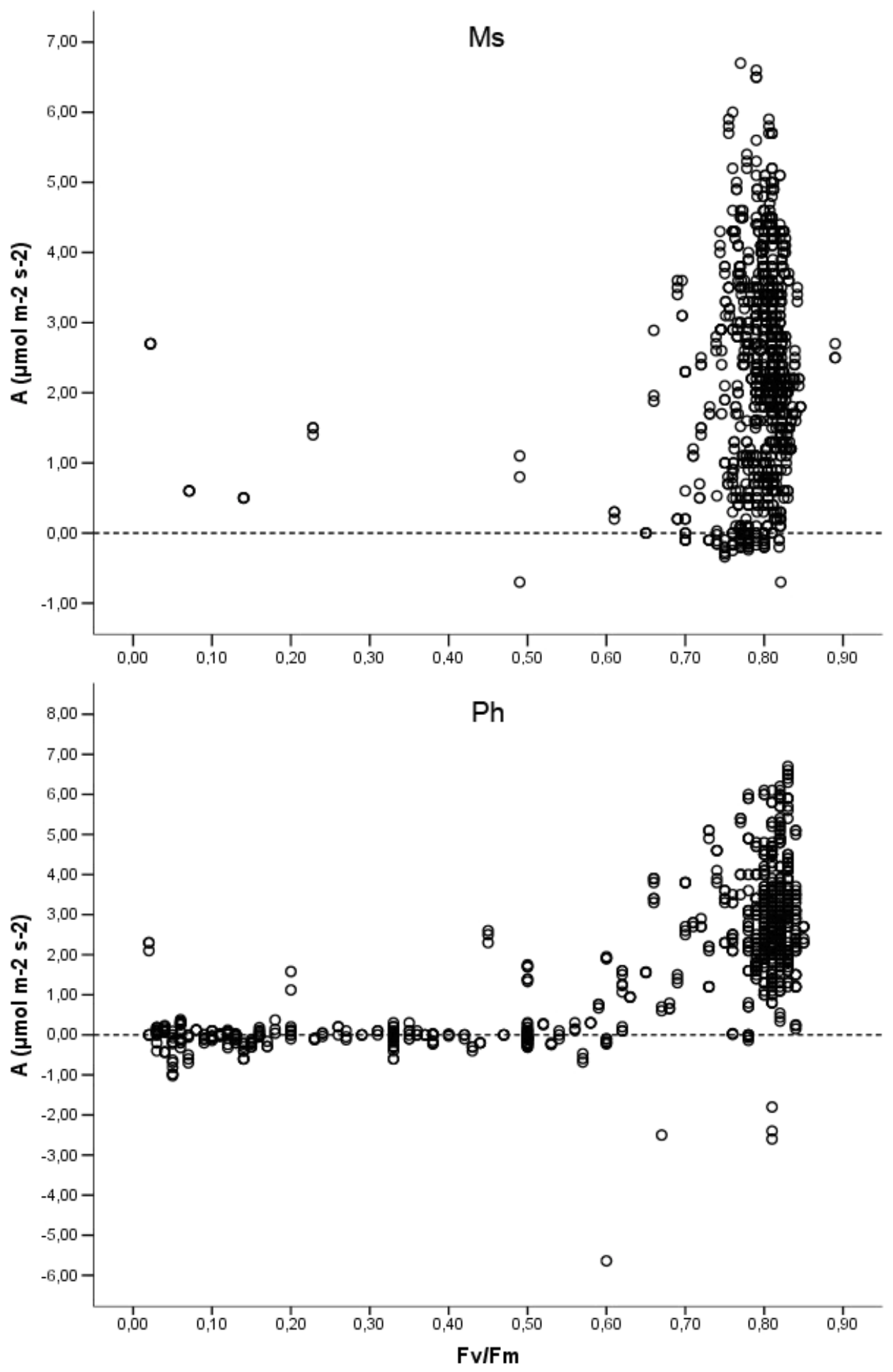

Figura 25 - Gráfico de dispersão representando a relação entre a assimilação líquida

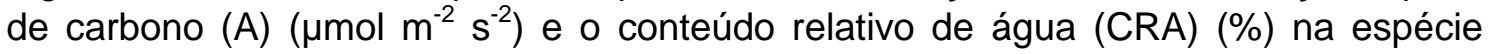
sensível a dessecação Microgramma squamulosa (Ms) e tolerante à dessecação Pleopeltis hirsutissima $(\mathrm{Ph})$ durante todo o período amostrado. A análise de regressão para P.hirsutissima apresentou um valor de $R^{2}$ igual a 0,491. Cada círculo representa uma folha. 

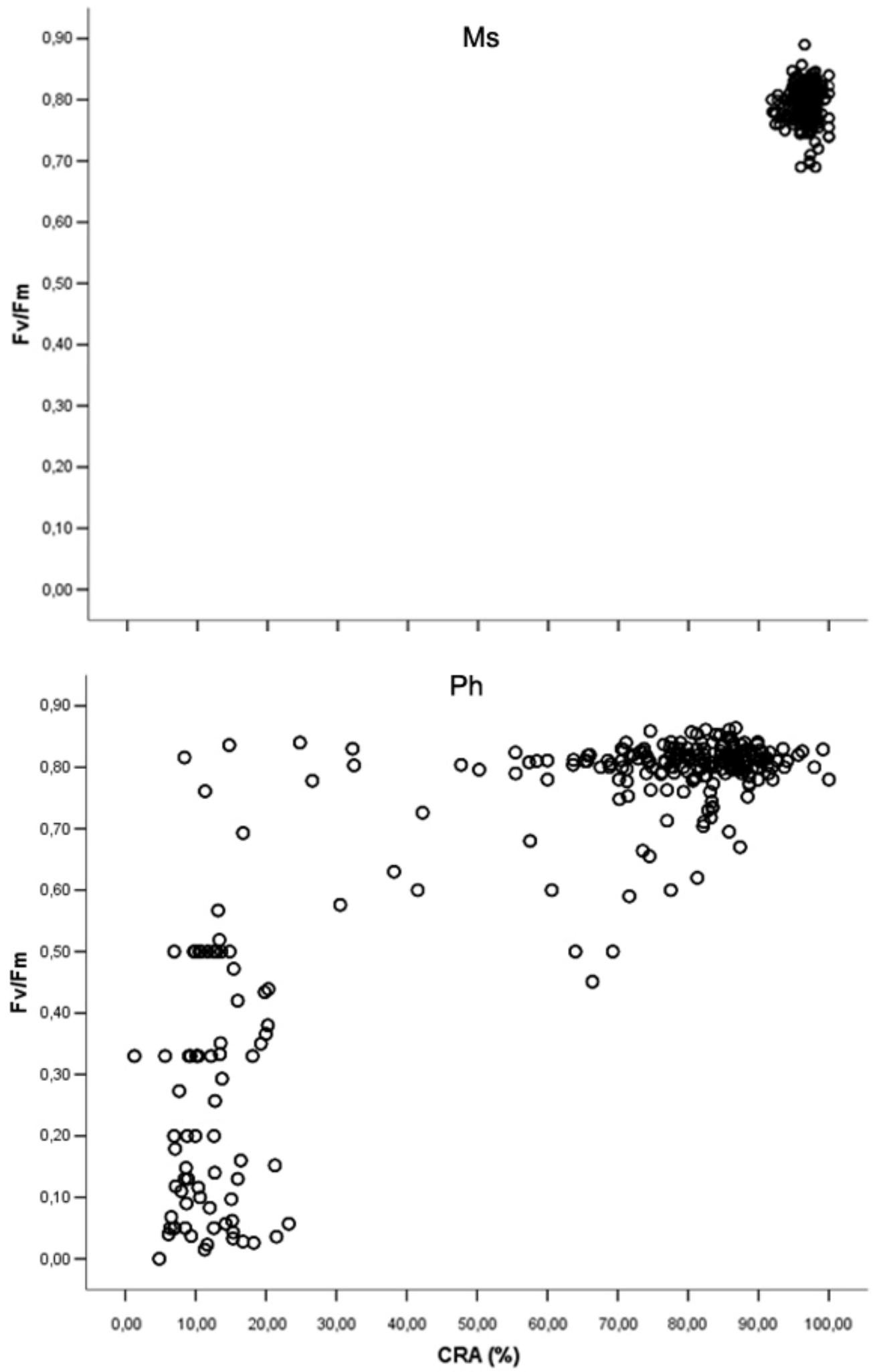

Figura 26 - Gráfico de dispersão representando a relação entre o rendimento quântico máximo aparente do PSII ( $\mathrm{Fv} / \mathrm{Fm}$ ) pelo conteúdo relativo de água (CRA) (\%) na espécie sensível a dessecação Microgramma squamulosa (Ms) e tolerante à dessecação Pleopeltis hirsutissima $(\mathrm{Ph})$ durante todo o período amostrado. A análise de regressão para $P$.hirsutissima apresentou um valor de $R^{2}$ igual a 0,723 . Cada círculo representa uma folha. 
3.3 Componentes de interação com a luz

\subsubsection{Pigmentos fotossintetizantes}

M. squamulosa apresentou uma concentração total por área foliar de pigmentos fotossintetizantes significativamente maior do que P.hirsutissima $(p<0,01)$. Folhas da face norte de M.Squamulosa $(n=96)$ apresentaram uma média de pigmentos totais igual a $64,633 \pm 2,22 \mu \mathrm{g} \cdot \mathrm{cm}^{-2}$, com máximo de $134,56 \mu \mathrm{g} \cdot \mathrm{cm}^{-2}$ e mínimo de $24,66 \mu \mathrm{g} \mathrm{cm}^{-2}$ e folhas de P.hirsutissima ( $\left.\mathrm{n}=97\right)$ igual a $50,547 \pm 1,560 \mu \mathrm{g} \cdot \mathrm{cm}^{-2}$, com máximo de 107,96 e mínimo de $29,10 \mu \mathrm{g} \cdot \mathrm{cm}^{-}$ 2. Folhas inseridas na face sul de M.squamulosa $(n=85)$ apresentaram uma média de $68,960 \pm 2,194 \mu \mathrm{g} \cdot \mathrm{cm}^{-2}$, com máximo de 124,37 e mínimo de $28,64 \mu \mathrm{g} \cdot \mathrm{cm}^{-2}$ e folhas de P.hirsutissima (n=92) igual a 53,295 $\pm 1,590 \mu \mathrm{g} \cdot \mathrm{cm}^{-2}$, com máximo de $121,44 \mu \mathrm{g} \cdot \mathrm{cm}^{-2}$ e mínimo de $30,48 \mu \mathrm{g} \cdot \mathrm{cm}^{-2}$. Não houve diferença significativa entre o conteúdo de pigmento entre indivíduos da face norte e sul da mesma espécie $(p=0,065)$ e a interação entre os fatores espécie e face do forófito não foi significativo $(p=0,100)$ (Figura 27). 


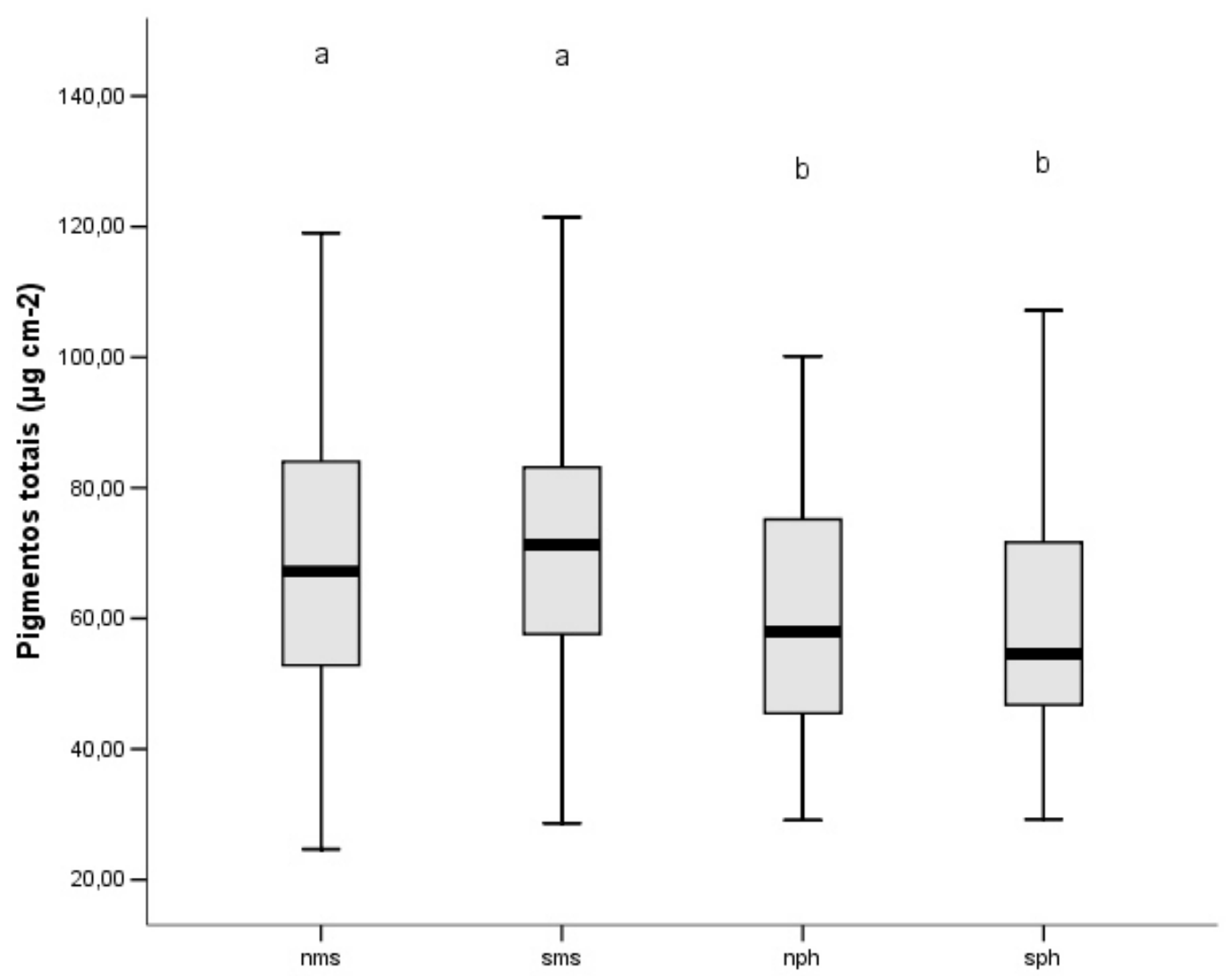

Figura 27 - Boxplot representando o conteúdo total de pigmentos $(\mu \mathrm{g} \cdot \mathrm{cm}-2)$ das folhas de Microgramma squamulosa presentes na face norte (nms) e sul (sms) do forófito e das folhas de Pleopeltis hirsutissima presentes na face norte (nph) e face sul (sph) do forófito $(p<0,05)$.

Folhas de M.squamulosa apresentaram maior conteúdo de carotenóides tanto na face norte $(n=96)$ quanto na face sul $(n=85)$ quando comparadas as folhas de P.hirsutissima (norte $n=97$; sul $n=92)(p<0,01)$. Folhas de M.squamulosa da face norte apresentaram uma média $8,009 \pm 0,324 \mu \mathrm{g} \cdot \mathrm{cm}^{-2}$, com máximo $18,57 \mu \mathrm{g} \cdot \mathrm{cm}^{-2}$ e mínimo $2,0157 \mu \mathrm{g} \cdot \mathrm{cm}^{-2}$ e folhas de P.hirsutissima apresentaram média igual a $6,576 \pm 0,20157 \mu \mathrm{g} \cdot \mathrm{cm}^{-2}$, com máximo de $11,836 \mu \mathrm{g} \cdot \mathrm{cm}^{-2}$ e mínimo de $2,876 \mu \mathrm{g} \cdot \mathrm{cm}^{-2}$. Folhas de M.squamulosa da face sul apresentaram uma média de $7,673 \pm 0,23957 \mu \mathrm{g} \cdot \mathrm{cm}^{-2}$, com máximo de $0,23957 \mu \mathrm{g} \cdot \mathrm{cm}^{-2}$ e mínimo de $3,2457 \mu \mathrm{g} \cdot \mathrm{cm}^{-2}$ e folhas de P.hirsutissima apresentaram uma média igual a $6,576 \pm 0,20057 \mu \mathrm{g} \cdot \mathrm{cm}^{-2}$, com máximo de 11,836 e mínimo e $2,876 \mu \mathrm{g} \cdot \mathrm{cm}^{-2}$. O fator face da árvore (norte, sul) não foi significativo $(p=0,684)$, nem a interação entre os fatores $(p=0,109)$ (Figura 28). 


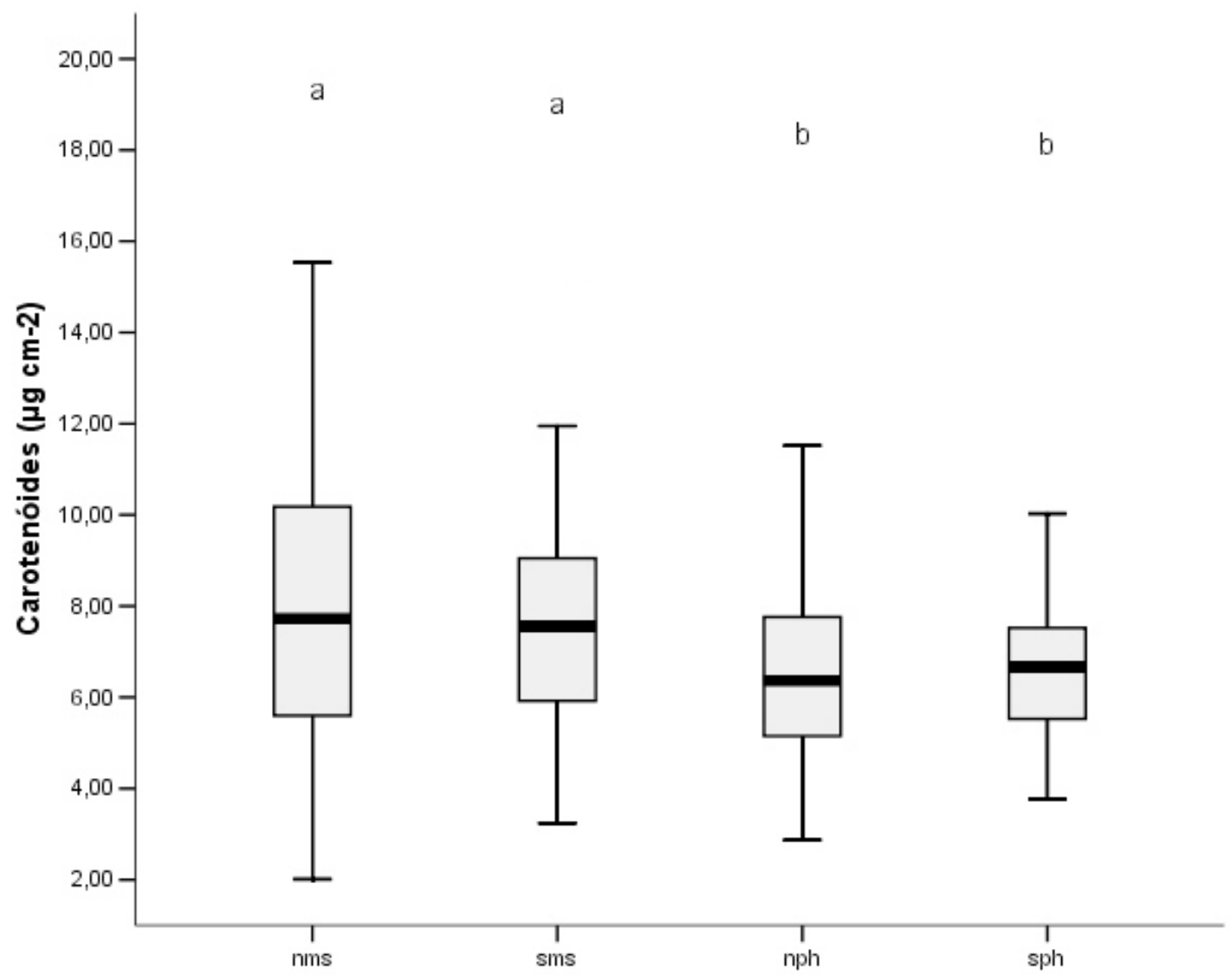

Figura 28 - Boxplot representando o conteúdo de carotenóides $(\mu \mathrm{g} \cdot \mathrm{cm}-2)$ das folhas de Microgramma squamulosa presentes na face norte (nms) e sul (sms) do forófito e das folhas de Pleopeltis hirsutissima presentes na face norte (nph) e face sul (sph) do forófito $(p<0,05)$.

A razão clorofila a / clorofila b foi maior em P.hirsutissima do que em M.squamulosa tanto na face norte quanto na face sul do forófito $(p<0,01)$. Indivíduos de P.hirsutissima coletadas da face norte $(n=98)$ apresentaram uma média igual a $1,373 \pm 0,268 \mu \mathrm{g} \cdot \mathrm{cm}^{-2}$, com máximo de 2,215 e mínimo de $0,576 \mu \mathrm{g} \cdot \mathrm{cm}^{-2}$ e M.squamulosa $(\mathrm{n}=96)$ apresentou uma média de $1,265 \pm 0,218 \mu \mathrm{g} \cdot \mathrm{cm}^{-2}$, com máximo 1,886 e mínimo $0,636 \mu \mathrm{g} \cdot \mathrm{cm}^{-2}$. Indivíduos de P.hirsutissima coletadas da face sul $(n=84)$ apresentaram média de $1,366 \pm 0,0256 \mu \mathrm{g} \cdot \mathrm{cm}^{-2}$, com máximo 1,96 e mínimo de $0,816 \mu \mathrm{g} \cdot \mathrm{cm}^{-2}$ e M.squamulosa da face sul ( $\mathrm{n}=95)$ apresentou uma média igual a $1,373 \pm 0,268 \mu \mathrm{g} \cdot \mathrm{cm}^{-2}$, com máximo de 2,12 e mínimo de $0,576 \mu \mathrm{g} \cdot \mathrm{cm}^{-2}$. Não foi encontrada diferença significativa entre a razão da clorofila $a$ e b entre indivíduos da face norte e sul da mesma espécie $(p=0,380)$ e a interação entre 
os fatores também não foi significativa $(p=0.377)$. Não foi encontrada relação entre o conteúdo de pigmentos e o conteúdo relativo de água em nenhuma das espécies (Figura 29).

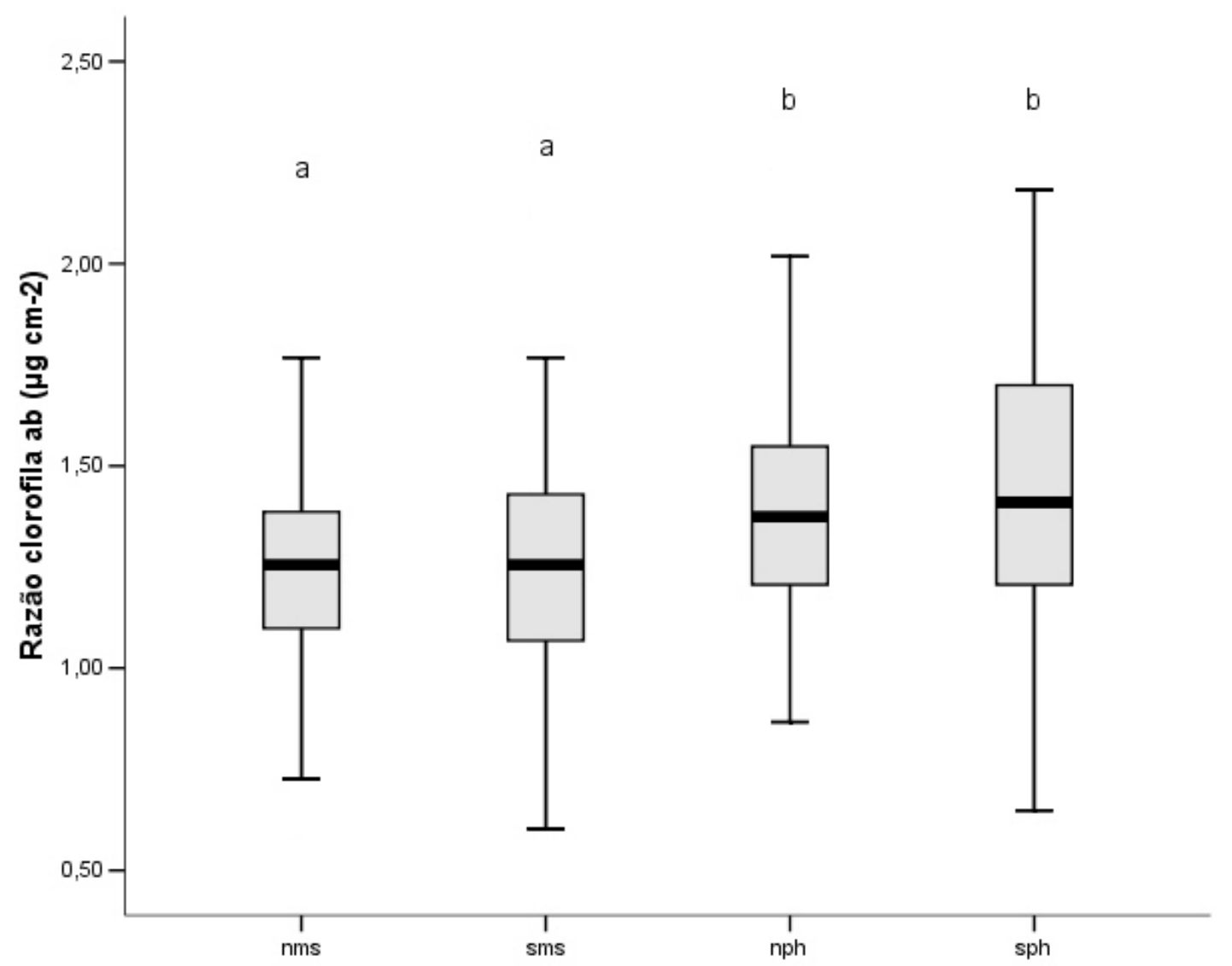

Figura 29 - Boxplot representando a razão da clorofila a sobre a clorofila b $(\mu \mathrm{g} \cdot \mathrm{cm}-2)$ das folhas de Microgramma squamulosa presentes na face norte (nms) e sul (sms) do forófito e folhas das Pleopeltis hirsutissima presentes na face norte (nph) e face sul (sph) do forófito $(p<0,05)$.

\subsubsection{Efeitos da interação entre luz e suspensão da provisão hídrica}

Os valores iniciais de Fv/Fm nas folhas das plantas de P.hirsutissima e M.squamulosa selecionadas apresentaram-se superiores a 0,75. Inicialmente, os valores de CRA de P.hirsutissima no tratamento exposto a luz apresentaram média inicial de $80,52 \pm 1,480 \%$. Plantas de P.hirsutissima do tratamento sombreado apresentaram CRA de $80,81 \pm 1,56 \%$. As folhas de M.squamulosa colocadas na luz obtiveram um CRA médio inicial de $96,31 \pm 0,26 \%$ e as colocadas na sombra de $96,06 \pm 0,66 \%$. 
Após um mês de suspensão da provisão hídrica, os valores de CRA de ambas as espécies apresentaram queda. Folhas de $P$.hirsutissima expostas ao sol apresentaram um CRA médio de 10,57 $\pm 1,00 \%$ e aquelas mantidas na

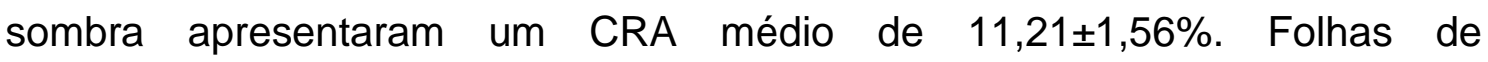
M.squamulosa mantidas expostas ao sol apresentaram uma média de $36,08 \pm 8,21 \%$ e as mantidas na sombra de $55,85 \pm 8,66 \%$.

Após um mês sem irrigação, nenhuma folha de P.hirsutissima e M.squamulosa exposta a luz manteve o valor de Fv/Fm acima de 0,75. P.hirsutissima e M.squamulosa expostas a luz alcançaram uma média de

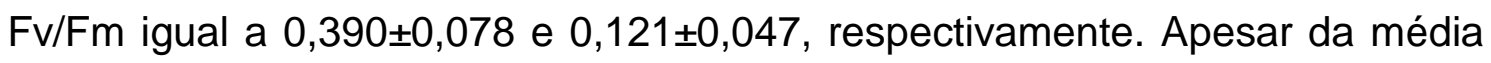
baixa de Fv/Fm, quatro folhas de P.hirsutissima apresentara, valores de Fv/Fm maior do que 0,6. Os maiores valores de Fv/Fm em M.squamulosa foram de 0,526 e 0,428 . Das quinze folhas de P.hirsutissima e M.squamulosa mantidas na sombra, quatro (27\%) de P.hirsutissima e nove (60\%) de M.squamulosa mantiveram valores de Fv/Fm acima de 0,75 após um mês sem irrigação. Os indivíduos de P.hirsutissima e M.squamulosa mantidos na sombra

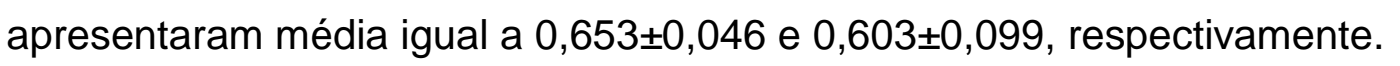

Após 12 horas do início da reidratação, folhas de P.hirsutissima expostas ao sol apresentaram CRA médio igual a 51,87 $\pm 4,14 \%$ e as mantidas na sombra de $71,28 \pm 4,03 \%$. As folhas de M.squamulosa expostas ao sol apresentaram uma média de CRA igual a 59,03 $\pm 9,03 \%$ e as mantidas na sombra de $92,77 \pm 0,83 \%$. Das 15 folhas de P.hirsutissima expostas a luz, quatro folhas (27\%) (pertencentes a três forófitos distintos) recuperaram o valor de Fv/Fm, alcançando ou ultrapassando o valor de 0,75. Apesar de apresentar um CRA mais elevado do que P.hirsutissima, nenhuma folha de M.squamulosa exposta a luz apresentou recuperação de seu sistema fotossintético. Mesmo as folhas com valores de Fv/Fm mais elevados anteriormente apresentaram queda do potencial de uso da luz. Quando às folhas de M.squamulosa mantidas na sombra, onze (73\%) de quinze apresentaram recuperação total aparente. Em contraste, dez (67\%) de quinze em P.hirsutissima mostraram-se completamente recuperadas.

Após uma semana da reidratação folhas de P.hirsutissima expostas a luz, das quinze folhas expostas nove (60\%) mostraram recuperação dos 
tecidos, porém apesar da recuperação de parte do tecido foliar, as raques de dois dos três forófitos apresentaram abscisão. Desta forma, a recuperação integral das folhas pode ser considerada em apenas quatro $(27 \%)$ folhas, todas pertencentes a um único forófito. Nenhuma folha de M.squamulosa que foi mantida ao sol se recuperou. Por outro lado, das folhas que foram mantidas sombreadas, catorze $(93 \%)$ de quinze em P.hirsutissima e doze $(80 \%)$ de quinze em M.squamulosa apresentaram recuperação do sistema fotossintético (Tabela 6).

Aparentemente, nos forófitos que continham M.squamulosa e que foram mantidos expostos a luz, apenas $10 \%$ das folhas que os cobriam apresentaram coloração verde e aparência túrgida do tecido ao final do ensaio. O restante das folhas de M.squamulosa apresentava coloração marrom e se tornou seco e quebradiço. De forma contrária, das folhas de M.squamulosa mantidas na sombra, quase a totalidade se manteve verde e túrgida.

Tabela 6 - Número de folhas de Microgramma squamulosa e Pleopeltis hirsutissima que apresentaram recuperação do rendimento quântico máximo aparente do uso da luz ( $\mathrm{Fv} / \mathrm{Fm})$, de um total de quinze folhas, após 12 horas e após sete dias da reidratação.

\begin{tabular}{lccc}
\hline & Tratamento & 12 horas & 7 dias \\
\hline M.squamulosa & exposta & 0 & 0 \\
M.squamulosa & sombreada & 11 & 12 \\
P.hirsutissima & exposta & 0 & 9 \\
P.hirsutissima & sombreada & 4 & 14 \\
\hline
\end{tabular}

Comparando o estado inicial (antes de serem submetidas a desidratação e reidratação) com o estado reidratado (12 horas após a reidratação), folhas de P.hirsutissima apresentaram quedas significativas quanto ao conteúdo de clorofila a, b, razão a/b e pigmentos totais, com exceção dos carotenóides. Em contraste, M.squamulosa apresentou somente um aumento significativo na razão de clorofila a/b. 


\subsubsection{Curva de resposta à luz}

A assimilação máxima projetada pela equação modelo apresentou uma

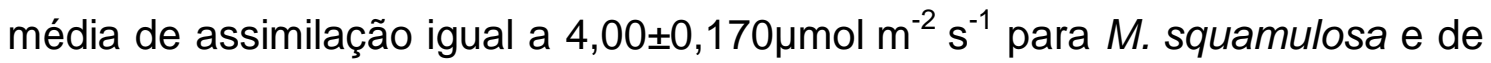
$6,90 \pm 0,624 \mu \mathrm{mol} \mathrm{m}{ }^{-2} \mathrm{~s}^{-1}$ para $P$. hirsutissima (Figura 30). $O$ ponto de compensação luminosa apresentou valor superior para P.hirsutissima, que obteve média de $10,735 \pm 2,30 \mu \mathrm{mol} \mathrm{m} \mathrm{m}^{-2} \mathrm{~s}^{-1}$ e M.squamulosa obteve uma média de $8,40 \pm 2,11 \mu \mathrm{mol} \mathrm{m} \mathrm{m}^{-2} \mathrm{~s}^{-1}$ (Figura 31). O rendimento quântico aparente apresentado por P.hirsutissima foi de 0,006 $\pm 0,0007$ e a de M.squamulosa foi de 0,105 $\pm 0,001$ (Figura 32).

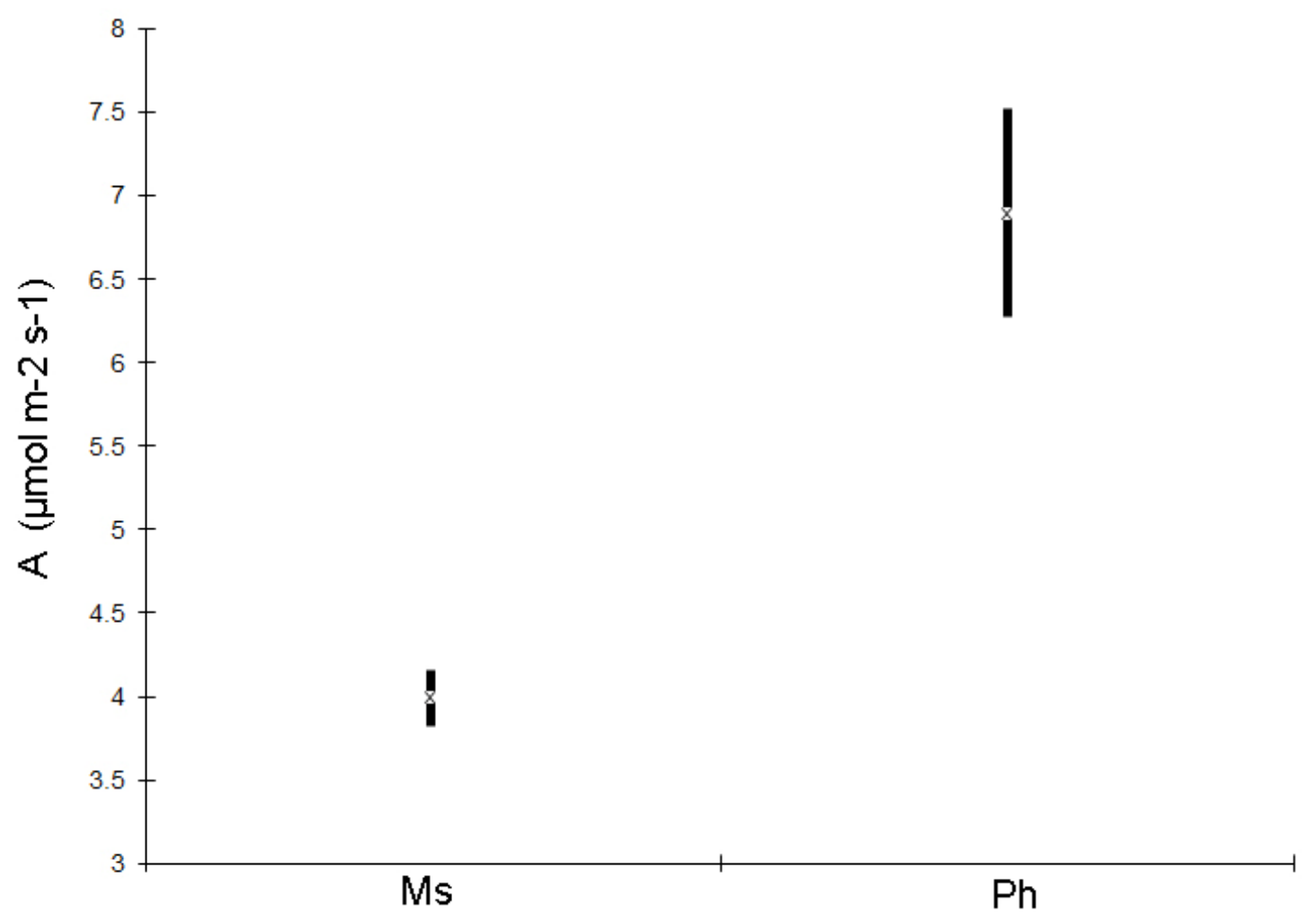

Figura 30 - Gráfico de barras representando a média e o erro padrão da assimilação de carbono máxima (A) $\mu \mathrm{mol} \mathrm{m}^{-2} \mathrm{~s}^{-1}$ ) estimada pelo modelo de hipérbole não quadrática aplicado às curvas de resposta à luz das espécies Pleopeltis hirsutissima $\left(6.900 \pm 0.624 \mu \mathrm{mol} \mathrm{m} \mathrm{m}^{-2} \mathrm{~s}^{-1}\right)$ e Microgramma squamulosa $\left(3,990 \pm 0,170 \mu \mathrm{mol} \mathrm{m} \mathrm{m}^{-2} \mathrm{~s}^{-1}\right)$. 


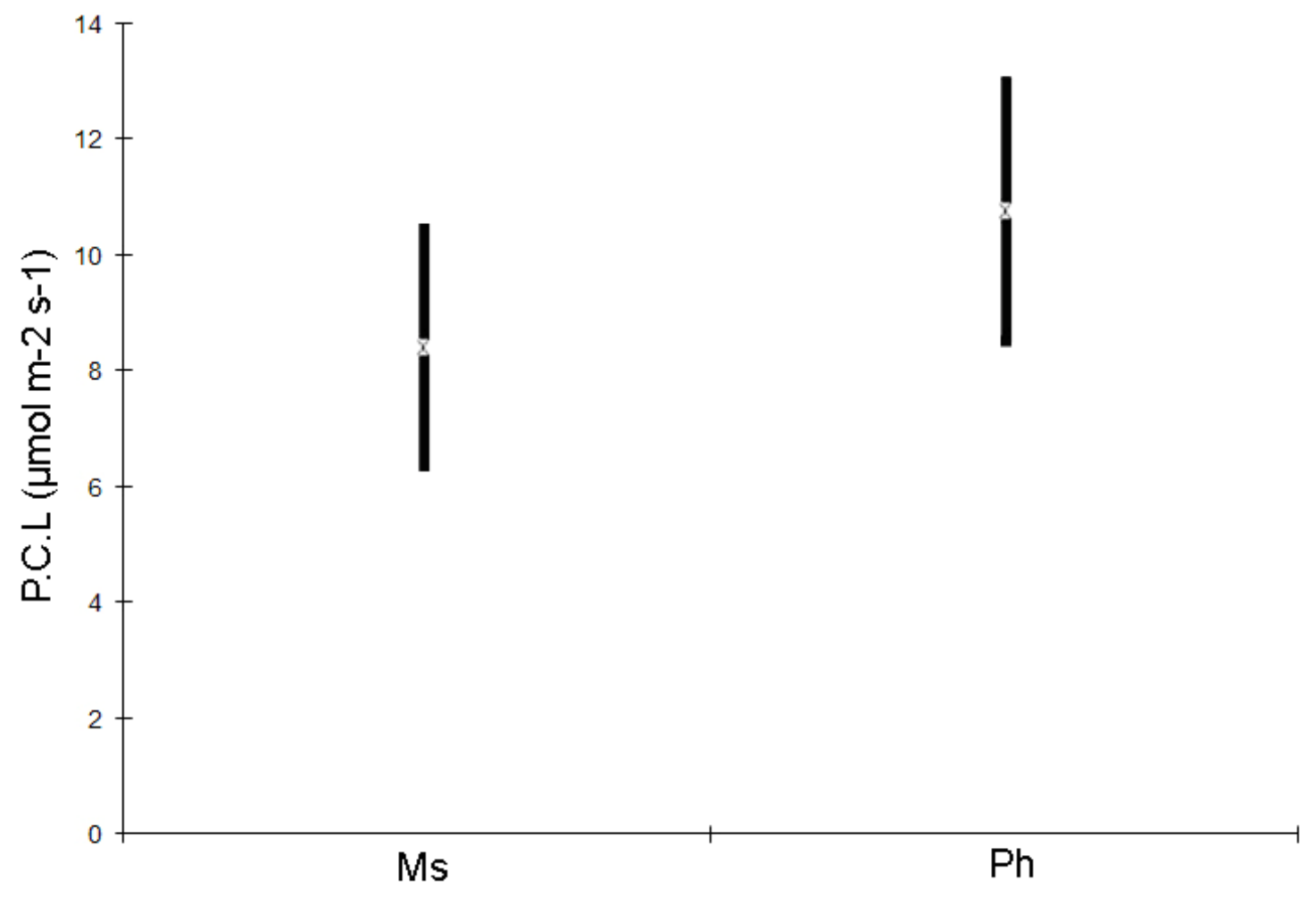

Figura 31 - Gráfico de barras representando a média e o erro padrão do ponto de compensação luminosa (P.C.L) $\left(\mu \mathrm{mol} \mathrm{m} \mathrm{m}^{-2} \mathrm{~s}^{-1}\right)$ estimada pelo modelo de hipérbole não quadrática aplicado às curvas de resposta à luz das espécies Microgramma squamulosa $\left(8,396 \pm 2,111 \mu \mathrm{mol} \mathrm{m}^{-2} \mathrm{~s}^{-1}\right)$ e Pleopeltis hirsutissima $\left(10,734 \pm 2,300 \mu \mathrm{molm}^{-2} \mathrm{~s}^{-1}\right)$. 


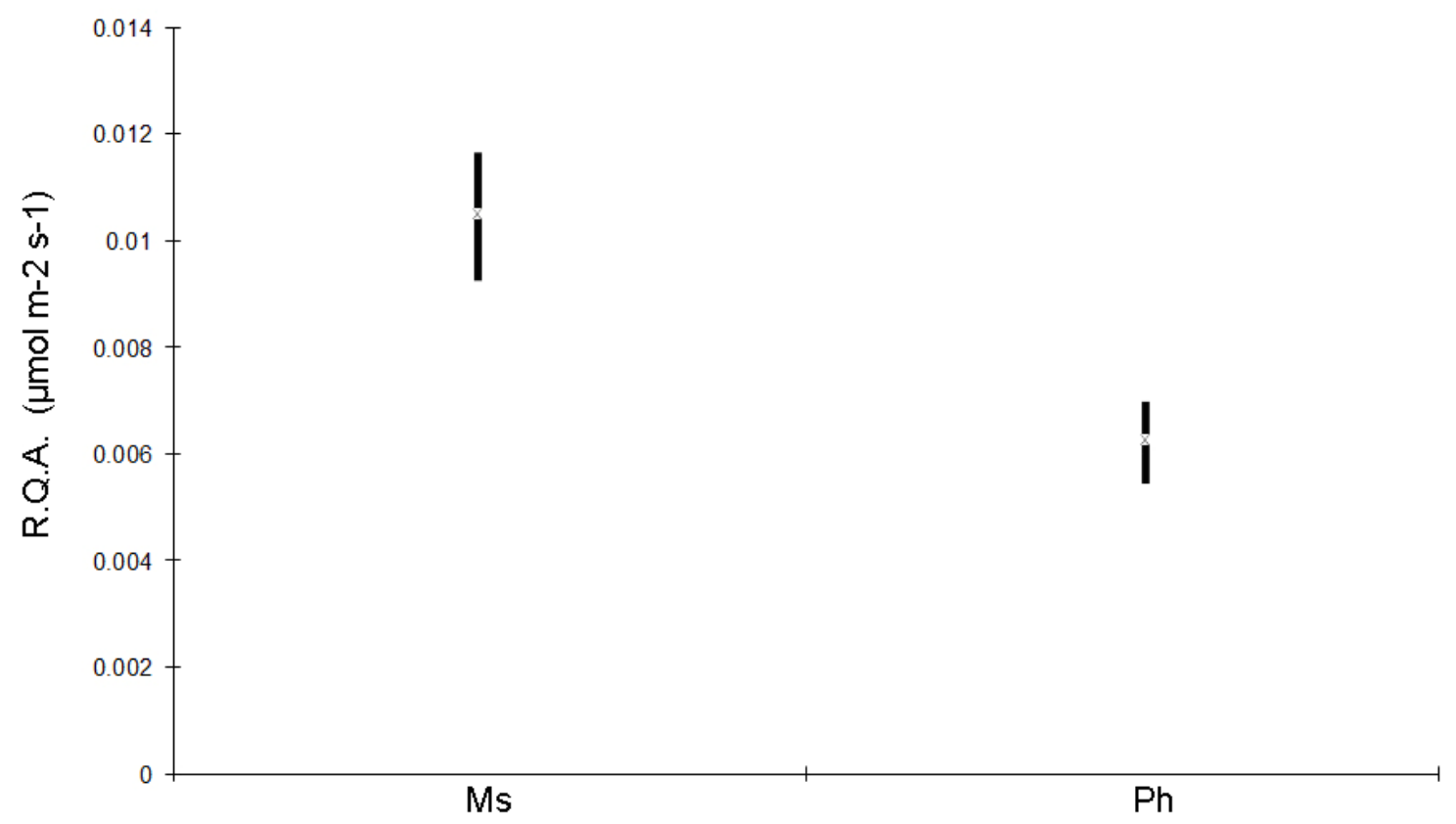

Figura 32 - Gráfico de barras representando a média e o erro padrão do rendimento quântico aparente (R.Q.A) $\left(\mu \mathrm{mol} \mathrm{m} \mathrm{m}^{-2} \mathrm{~s}^{-1}\right)$ estimado pelo modelo de hipérbole não quadrática aplicado às curvas de resposta à luz das espécies Pleopeltis hirsutissima $\left(10,734 \pm 2,300 \mu \mathrm{mol} \mathrm{m}^{-2} \mathrm{~s}^{-1}\right)$ e Microgramma squamulosa $\left(8,396 \pm 2,111 \mu \mathrm{mol} \mathrm{m}^{-2} \mathrm{~s}^{-1}\right)$.

P. hirsutissima e M.squamulosa apresentaram queda da assimilação ao longo dos quatro dias amostrados. Inicialmente M.squamulosa apresentou uma assimilação média de $3,881 \pm 0,177 \mu \mathrm{mol} \mathrm{m}^{-2} \mathrm{~s}^{-1}$ e P.hirsutissima de $2,302 \pm 0,067 \mu \mathrm{mol} \mathrm{m}^{-2} \mathrm{~s}^{-1}$. No segundo dia, M.squamulosa apresentou uma grande queda em sua assimilação, obtendo assimilação média igual a $2,700 \pm 0,0672 \mu \mathrm{mol} \mathrm{m}^{-2} \mathrm{~s}^{-1}$. Já P.hirsutissima manteve sua assimilação, apresentando aumento de $0,148 \mu \mathrm{mol} \mathrm{m}^{-2} \mathrm{~s}^{-1}$, com uma média igual a $2,450 \pm 0,051 \mu \mathrm{mol} \mathrm{m} \mathrm{m}^{-2} \mathrm{~s}^{-1}$. No terceiro dia M.squamulosa e P.hirsutissima apresentaram médias de 2,069 $\pm 0,0682 \mu \mathrm{mol} \mathrm{m}^{-2} \mathrm{~s}^{-1}$ e 1,657 $\pm 0,048 \mu \mathrm{mol} \mathrm{m}^{-2} \mathrm{~s}^{-1}$, respectivamente. E no quarto dia M.squamulosa apresentou média de $1,185 \pm 0,066 \mu \mathrm{mol} \mathrm{m} \mathrm{m}^{-2} \mathrm{~s}^{-1}$ e P.hirsutissima de $1,835 \pm 0,678 \mu \mathrm{mol} \mathrm{m} \mathrm{m}^{-2} \mathrm{~s}^{-1}$ (Tabela 7). 
Tabela 7 - Assimilação de carbono (A) $\left(\mu \mathrm{mol} \mathrm{m} \mathrm{m}^{-2} \mathrm{~s}^{-1}\right)$ mensurada durante quatro dias em folhas de Microgramma squamulosa e Pleopeltis hirsutissima em processo de dessecação.

\begin{tabular}{lcc}
\hline \multicolumn{3}{c}{$\mathbf{A}\left(\boldsymbol{\mu} \mathbf{m o l ~}^{-2} \mathbf{s}^{-1}\right)$} \\
\hline Dia 1 & Microgramma squamulosa & Pleopeltis hirsutissima \\
Dia 2 & $3,881 \pm 0,177$ & $2,302 \pm 0,067$ \\
Dia 3 & $2,692 \pm 0,067$ & $2,398 \pm 0,051$ \\
Dia 4 & $2,000 \pm 0,068$ & $1,608 \pm 0,048$ \\
\hline
\end{tabular}

P.hirsutissima e M.squamulosa apresentaram respostas distinta quanto ao ponto de compensação luminoso ao longo do tempo. P.hirsutissima apresentou aumento do ponto de compensação luminoso durante a dessecação dos tecidos, apresentando média igual a $16,602 \pm 1,410 \mu \mathrm{mol} \mathrm{m} \mathrm{m}^{-2} \mathrm{~s}^{-}$ ${ }^{1}, 18,277 \pm 1,246 \mu \mathrm{mol} \mathrm{m}^{-2} \mathrm{~s}^{-1}, 20,815 \pm 2,106 \mu \mathrm{mol} \mathrm{m}^{-2} \mathrm{~s}^{-1}$ e 20,035 $\pm 3,120 \mu \mathrm{mol} \mathrm{m}^{-} \mathrm{s}^{-}$ 1. Em contraste o ponto de compensação luminoso M.squamulosa apresentou diminuição seguida de um aumento no último dia mensurado, os valores médios obtidos foram: $13,766 \pm 2,155 \mu \mathrm{mol} \mathrm{m}^{-2} \mathrm{~s}^{-1} ; 13,766 \pm 1,363 \mu \mathrm{mol} \mathrm{m} \mathrm{m}^{-2} \mathrm{~s}^{-1}$; $10,721 \pm 1,424 \mu \mathrm{mol} \mathrm{m}^{-2} \mathrm{~s}^{-1}$ e 14,123 $\pm 1,686 \mu \mathrm{mol} \mathrm{m}^{-2} \mathrm{~s}^{-1}$ (Tabela 8).

Tabela 8 - Ponto de compensação luminosa (P.C.L) $\left(\mu \mathrm{mol} \mathrm{m} \mathrm{m}^{-2} \mathrm{~s}^{-1}\right)$ mensurada durante quatro dias em folhas de Microgrammasquamulosa e Pleopeltis hirsutissima em processo de dessecação.

\begin{tabular}{lcc}
\hline \multicolumn{3}{c}{ P.C.L $\left(\boldsymbol{\mu m o l ~ \mathbf { ~ m } ^ { - 2 } \mathbf { s } ^ { - 1 } )}\right.$} \\
\hline Mia 1 & Microgramma squamulosa & Pleopeltis hirsutissima \\
Dia 2 & $13,766 \pm 2,155$ & $16,601 \pm 1,409$ \\
Dia 3 & $13,766 \pm 1,364$ & $18,277 \pm 1,246$ \\
Dia 4 & $10,721 \pm 1,424$ & $20,815 \pm 2,106$ \\
\hline
\end{tabular}


Inicialmente a rendimento quântico aparente da assimilação de M.squamulosa apresentou um valor mais baixo do que P.hirsutissima, sendo a média de M.squamulosa igual a 0,008 $\pm 0,0005$ e de P.hirsutissima $0,119 \pm 0,0007$. No segundo dia P.hirsutissima apresentou um pequeno aumento em sua eficiência quântica, obtendo média de 0,012 $\pm 0,0006$ e M.squamulosa apresentou um grande aumento, obtendo média igual a $0,113 \pm 0,0009$, ultrapassando o valor de eficiência de P.hirsutissima. No terceiro dia os valores se mantiveram estáveis, apresentando médias de 0,013 $\pm 0,001$ e 0,012 $\pm 0,001$ para M.squamulosa e P.hirsutissima, respectivamente. No último dia P.hirsutissima também manteve sua eficiência quântica, com uma média de $0,012 \pm 0,004$, porém M.squamulosa apresentou um grande aumento, obtendo média igual a 0,023 $\pm 0,004$ (Tabela 9).

Tabela 9 - Rendimento quântico aparente (R.Q.A) $\left(\mu \mathrm{mol} \mathrm{m} \mathrm{m}^{-2} \mathrm{~s}^{-1}\right)$ mensurada durante quatro dias em folhas de Microgramma squamulosa e Pleopeltis hirsutissima em processo de dessecação.

\begin{tabular}{|c|c|c|}
\hline \multicolumn{3}{|c|}{ 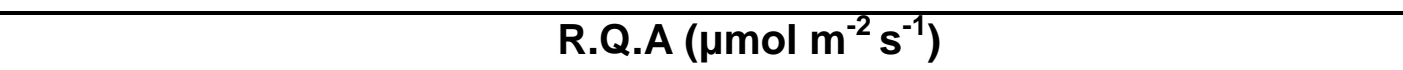 } \\
\hline & Microgramma squamulosa & Pleopeltis hirsutissima \\
\hline Dia 1 & $0,008 \pm 0,0005$ & $0,0119 \pm 0,0007$ \\
\hline Dia 2 & $0,013 \pm 0,0009$ & $0,012 \pm 0,0006$ \\
\hline Dia 3 & $0,013 \pm 0,001$ & $0,012 \pm 0,001$ \\
\hline Dia 4 & $0,022 \pm 0,003$ & $0,012 \pm 0,004$ \\
\hline
\end{tabular}




\section{Discussão}

\subsection{Estrutura da comunidade}

No ambiente epifítico da Universidade de São Paulo o número de espécies SD é superior ao número de espécies TD. Entretanto, o resultado obtido quanto à frequência dessas estratégias (SD e TD) apresentou valores semelhantes. Nos 114 forófitos amostrados, foram avistadas 195 vezes espécies SD e 182 vezes espécies TD, resultando em uma frequência de 1,7 espécies SD para 1,6 espécies TD por forófito, indicando possuírem mecanismos satisfatórios para superarem o filtro ambiental do ambiente em questão.

A maior parte das espécies SD apresentam características que permitem inferir a existência de sistemas especiais de resistência ao estresse hídrico. Entre estes está a ocorrência de metabolismo ácido de crassuláceas (CAM) em algumas das espécies de bromeliaceae que constituem o grupo de "broméliastanque" (Aechmaea distichanta e Aechmaea bromeliifolia), as cactáceas do gênero Rhipsalis (Rhipsalis baccifera e R. trigona) e as tillandsias. Esse fato, somado ao fato de que espécies TD também possuem uma frequência considerável nos forófitos amostrados, é coerente com a perspectiva de que a superfície do tronco impõe sérias limitações ao estabelecimento de plantas que não possuem sistemas de resistência à seca extrema, dado que a pequena quantidade de substrato faz com que a água seja disponível de forma espasmódica.

Mesmo com as sérias limitações impostas pelo ambiente epifítico, a espécie mais frequente e mais abundante no ambiente estudado foi a SD Microgramma squamulosa. É possível propor que a alta abundância de M.squamulosa se deva aos custos menos elevados associados com sua estratégia, o que poderia levar a espécie apresentar uma maior produtividade.

Após M.squamulosa, a segunda e terceira maiores frequências foram apresentadas pelas espécies TD P.hirsutissima e P.pleopeotifolia. Nas análises de ordenação e agrupamento a espécie M.squamulosa apareceu agrupada com essas espécies TD (P.hirsutissima e P.pleopeotifolia) e também com a TD $P$.astrolepis, que apareceu em quarto lugar no ranking de frequência. Esses dados representam a existência de uma homogeneidade entre as espécies 
citadas, indicando uma alta associação espacial que poderia fazer presumir que existe uma sobreposição de nicho, ou até mesmo uma interação positiva entre elas. Essa observação é consistente com a hipótese inicial do trabalho, de que a coexistência entre as espécies TD e SD é facilitada pela diferenciação de nichos.

A análise de ordenação distingue claramente os dois principais grupos de estratégias de uso da água. Em relação ao grupo das TD com a única exceção é a superposição de M.squamulosa. Essa evidência conduziu a abordagem deste trabalho, já que sugere o maior grau de superposição de habitat entre as SD e TD. A superposição estaria associada ao forófito, não significando necessariamente uma superposição espacial evidente, já que o volume que o forófito ocupa pode dar lugar a uma grande diversidade de microhabitats.

As análises complementares utilizando a técnica de agrupamento foram coerentes com 0 arranjo da ordenação e ressaltam a associação entre P.hirsutissima e M.squamulosa, o que permitiria sugerir a associação de independência entre as duas espécies por processos de facilitação ou até mesmo considerar a possibilidade de um processo de competição em curso. Entretanto, a maior possibilidade seria a segregação entre os nichos de P.hirsutissima e M.squamulosa condicionada pela distinção na forma de uso da água. 


\subsection{Ecofisiologia de Microgramma squamulosa}

A espécie Microgramma squamulosa, apresentou um comportamento típico de espécies sensíveis à dessecação, apresentando valores de CRA $(97,00 \pm 1,53)$ e $\mathrm{Fv} / \mathrm{Fm}(0,796 \pm 0,029)$ constantes ao longo de todo o período estudado. Porém, comparando a média de assimilação de M.squamulosa do período úmido $\left(2,9698 \pm 0,0619 \mu \mathrm{mol} \mathrm{m}^{-2} \mathrm{~s}^{-1}\right)$ e do período seco $(0,896 \pm$ $\left.0,114 \mu \mathrm{mol} \mathrm{m} \mathrm{m}^{-2} \mathrm{~s}^{-1}\right)$, fica evidente a queda na sua atividade fotossintética, indicando que M.squamulosa foi submetida a condições que conferiram estresse durante o período de seca.

No início da seca a resposta de plantas vasculares se dá predominantemente através da limitação estomática, em que ocorre um progressivo fechamento estomático, acompanhado de forma paralela pela diminuição da taxa fotossintética líquida da planta (MEDRANO et al., 2002). Somente quando o CRA alcança valores abaixo de $70 \%$, correspondendo a uma seca moderada, a fixação fotossintética de carbono e o transporte de elétrons são comprometidos pelo fechamento estomático (CORNIC et al.,1992; GODDE, 1999, p.451). Porém, apesar de apresentar um CRA mínimo de 92\% durante o período seco, M.squamulosa apresentou uma queda alta dos valores de condutância estomática (provavelmente responsável pela manutenção do CRA) e da taxa de transferência de elétrons.

Esses dados sugerem que outro fator, que não a perda de água, foi a causa da redução de assimilação de carbono. De acordo com Kaiser (1987), em condições de seca natural, fatores como a temperatura e a alta irradiação contribuem mais para a inibição da fotossíntese do que a própria perda de água. Por sua vez, a diminuição do ETR reflete a queda na taxa de assimilação de carbono, uma vez que sob condição de estresse, o transporte de elétrons se adapta para uma baixa demanda de assimilados e capacidade de fixação de carbono (GODDE, 1999, p.451).

Embora M.squamulosa tenha mantido valores de $\mathrm{Fv} / \mathrm{Fm}$ próximos a 0,8 , indicando ser capaz de utilizar a luz durante todo o período estudado, houve um aumento da variação nos valores da fluorescência basal (Fo) e da fluorescência máxima $(F m)$ no período seco e, apesar de não ser significativo, foi possível observar uma tendência de aumento do Fo e diminuição do Fm. 
Esse padrão nos valores de fluorescência, com valores altos de Fo, pode indicar o comprometimento do PSII ou então que a transferência da energia de excitação da antena para os centros de reação esteja prejudicada (BOLHAR-NORDENKAMPF et al., 1989). Resultados semelhantes foram observados na espécie SD Spinacea oleracea (GEORGIEVA et al., 2007) e na pteridófita Selaginella lepidophylla (TD), cujo enrolamento foliar foi impedido propositalmente para verificar os efeitos da luz sobre o tecido (CASPER; EICKMEIER; OSMOND, 1993; LEBKUECHER; EICKMEIER, 1993).

De acordo com Watkins et al. (2006), o centro de reação fecha (reduzido) quando recebe mais luz do que ele consegue transferir. Existem plantas cujo desempenho fotossintético cai sob iluminação excessiva, sendo grande parte delas criptógamas (LARCHER, 2003). Dessa forma, é possível sugerir que a queda da assimilação seja devido à alta irradiação sobre as plantas no ambiente epifítico durante o período seco, em que M.squamulosa está sujeita ao estresse hídrico. Essa hipótese é reforçada pela observação realizada em campo de que, durante o período seco, os forófitos da espécie tipuana, que são os mais frequentes na cidade universitária, perdem suas folhas, aumentando ainda mais a exposição das epífitas a luz. Durante essa época foi possível observar folhas de M.squamulosa e outras pteridófitas SD, principalmente a Serpocaulon catharinae, em senescência.

\subsection{Ecofisiologia de Pleopeltis hirsutissima}

A alta variação dos valores de CRA em P.hirsutissima é característica de espécies tolerantes a dessecação. Durante o período de transição a condutância estomática superior ao do período úmido sugere a admissão da perda de água de forma a permitir com que seus tecidos entrassem em equilíbrio dinâmico com a umidade relativa do ar.

Durante o período seco, P.hirsutissima apresentou valores baixos de Fv/Fm, ausência de Fv'/Fm', inativação completa da taxa de transferência de elétrons e ausência de assimilação fotossintética, sugerindo a entrada das folhas no estado de anabiose. A condutância estomática também apresentou queda de seus valores, porém provavelmente teve como causa o baixo CRA $(11,940 \pm 0,535 \%)$. 
Através da análise de regressão foi possível observar que as variáveis mais importantes para explicar a assimilação de carbono em Pleopeltis hirsutissima foram o CRA e o Fv/Fm. P.hirsutissima inicia uma queda abrupta de sua assimilação de carbono quando seu CRA atinge valores abaixo de $60 \%$ e valores de $\mathrm{Fv} / \mathrm{Fm}$ abaixo de aproximadamente 0,75 . Os valores de assimilação ficam próximos a $0 \mu \mathrm{mol} \mathrm{m}^{-2} \mathrm{~s}^{-1}$ quando os valores de CRA atingem em torno de $20 \%$ e os de $\mathrm{Fv} / \mathrm{Fm}$ o atingem em torno de 0,6. A regressão entre o CRA e o Fv/Fm indicou que o declínio do Fv/Fm também inicia quando o CRA atinge um valor em torno de $60 \%$. Logo, os dados sugerem que quando 0 CRA atinge $60 \%$, a assimilação de carbono e o potencial de uso da luz decaem e caracterizam o início do processo que tem como destino o estado de anabiose.

Em Mohria caffrorum (FARRANT et al., 2009), uma pteridófita que apresenta a capacidade de tolerar a dessecação de forma sazonalmente regulada, as folhas TD apresentaram o declínio do Fv/Fm quando o conteúdo relativo de água alcançou valores abaixo de $70 \%$. Em contraste, suas folhas SD apresentaram declínio dos valores de Fv/Fm quando seu CRA alcançou valores abaixo de $46 \%$. Entretanto, quando as folhas SD atingiram um CRA de $60 \%$, apresentaram o aumento do vazamento de eletrólitos, indicando danos nos tecidos.

Ao contrário das folhas TD, as folhas SD de M.caffrorum não se recuperaram após a reidratação. Esse resultado sugere que nas TD, o declínio do Fv/Fm inicia antes de um nível de perda de água que danifique os tecidos, sendo possível propor que ao mesmo tempo os mecanismos de proteção devem ser induzidos para evitar que a consequente capacidade de uso da luz reduzida leve a danos foto-oxidativos (FARRANT et al., 2009). O mesmo deve ocorrer com P.hirsutissima, podendo então sugerir que quando seu CRA alcança valores em torno de $60 \%$, a indução de seus mecanismos de proteção tem início ou já estão montados com o objetivo de atravessar o período de seca sem danos.

Além disso, de acordo com Farrant (2000), cessar a atividade fotossintética quando o conteúdo relativo de água do tecido se encontra em níveis altos tem como propósito minimizar o potencial de danos foto-oxidativos. 
Farrant propõe que a formação de um sistema de proteção contra danos fotooxidativos eficiente dependa da respiração enquanto que a mesma se encontre hidratada o suficiente para manter seu metabolismo.

Quando a fotossíntese é inibida em consequência ao baixo conteúdo de água, a luz absorvida pela planta pode causar um excesso de energia de excitação e um potencial de foto-inibição, sendo a planta incapaz de dissipar toda a energia de forma ordenada (BIEHLER; FOCK, 1996). Nessas condições, mesmo níveis baixos de luz $\left(50 \mu \mathrm{mol} \cdot \mathrm{m}^{-2} \cdot \mathrm{s}^{-1}\right)$ podem causar danos (CASPER; EICKMEIER; OSMOND, 1993).

$\mathrm{O}$ próprio decaimento concomitante entre $\mathrm{CRA}$ e $\mathrm{Fv} / \mathrm{Fm}$, evidenciado pela alta regressão $\left(R^{2}=0,747\right)$, pode funcionar como um mecanismo de proteção físico dos tecidos. Em consequência da perda de água, as folhas se enrolam de forma a evitar a exposição de seus tecidos quando a planta não consegue utilizar a luz de forma eficiente. $O$ enrolamento foliar é um movimento de auto-sombreamento em que a área de tecido foliar exposto diminui para reduzir a produção de radicais livres, funcionando como um mecanismo de proteção contra a luz (LEBKUECHER; EICKMEIER, 1993; SHERWIN; FARRANT, 1998; ALPERT, 2000) e também quanto altas temperaturas (LEBKUECHER; EICKMEIER, 1993).

Foi possível observar que folhas de P.hirsutissima apresentam enrolamento foliar e apresentam tricomas. De acordo com Watkins et al. (2006), os tricomas auxiliam na proteção do fotossistema contra a luz, diminuindo a exposição dos tecidos e auxiliando evitar a foto inibição e uma melhor recuperação das folhas após a reidratação.

O valores de Fo máximo em P.hirsutissima foi maior no período seco do que os valores apresentados no período úmido, o que pode indicar estresse ou e a presença de danos no fotossistema. $O$ fato de que os mecanismos necessários à viabilidade das plantas TD indutivas sejam iniciados durante a fase de dessecação explica o motivo da necessidade dessas espécies dessecarem mais lentamente que as TD constitutivas, que mantêm os mecanismos sempre prontos (OLIVER et al., 2000). Dessa forma, é possível propor que os valores mais altos de Fo no período seco podem ser recorrentes de condições de dessecação diferente do ótimo, como uma perda mais rápida 
de água, impedindo a preparação eficiente dos tecidos para suportar o estado de anabiose.

As condições em que as plantas TD sofrem o processo de dessecação e reidratação e o tempo de permanência dos tecidos em estado dessecado também possuem grande influência ao subsequente estado fisiológico e a recuperação da capacidade fotossintética da planta (EICKMEIER, 1983; HARTER; EICKMEIER, 1987). A rápida dessecação em plantas vasculares é, em geral, mostrada como um processo mais prejudicial para o tecido vegetativo quando comparado à dessecação lenta em uma grande variedade de táxons (EICKMEIER, 1983; GAFF, 1997).

\subsection{Ecofisiologia comparativa}

As altas variações de parâmetros como o CRA e o $\mathrm{Fv} / \mathrm{Fm}$ em P.hirsutissima em comparação aos valores constantes do CRA e do Fv/Fm em M.squamulosa refletem as respostas fisiológicas contrastantes das espécies lidarem com o estresse hídrico apresentado no ambiente epifítico.

Quando a seca atinge um nível moderado, ocorre a redução da carboxilação (fixação de $\mathrm{CO}_{2}$ ), redução de processos fotoquímicos e a baixa taxa $\mathrm{CO}_{2}$. Em conjunto, esses fatores desencadeiam a formação de xantofilas, auxiliando na dissipação térmica do excesso de energia luminosa (considerado um dos principais mecanismos para neutralizar a produção de espécies reativas de oxigênio no cloroplasto). Até esse nível de dessecação (moderado), espécies TD e SD são capazes de retomar os processos fotoquímicos até seu máximo, porém quando o déficit hídrico atinge esse nível, os danos causados são irreversíveis para plantas SD (MEDRANO et al., 2002; FERNÁNDEZMARÍN et al., 2011).

Pelo fato do nível de seca severa causar danos irreversíveis para espécies SD, M.squamulosa mantêm seu CRA enquanto P.hirsutissima permite variações extremas e que alcance níveis da seca severa protegida por mecanismos exclusivos da estratégia (BLOMSTEDT et al, 2010). Esse fato pode explicar a eficiência do uso da água superior encontrada em M.squamulosa durante o período úmido e seco, já que a perda de água para M.squamulosa deve ser mais custoso devido sua estratégia de uso da água. 
As respostas fisiológicas contrastantes entre TD e SD refletem estados fisiológicos distintos frente às condições ambientais. De acordo com os resultados obtidos pela análise de mistura para o CRA, a distribuição de P.hirsutissima é claramente bimodal, indicando haver dois estados fisiológicos naturais à estratégia TD, sendo possível sugerir que são: o estado de atividade metabólica $(82,182 \% \pm 6,904)$ e o estado de anabiose $(11,658 \% \pm 4,675)$.

M.squamulosa também apresentou dois subgrupos na a análise de mistura pra o CRA. Levando em conta a estratégia SD, os possíveis estados em consequência ao CRA em M.squamulosa são de viabilidade $(97,061 \% \pm$ $1,3033)$ e inviabilidade ou danos dos tecidos $(79,625 \% \pm 19,868)$, sendo esse último provavelmente um estado irreversível no qual a folha entra em senescência. A probabilidade de ocorrência de folhas que apresentam o estado de inviabilidade dos tecidos é baixa $(0,110)$, podendo sugerir que esse estado se trata mais de uma exceção, que indica folhas senescentes, do que um estado fisiológico propriamente dito.

Apesar do resultado da análise de mistura para CRA indicar dois subgrupos para P.hirsutissima, no histograma é possível observar uma frequência considerável de valores entre as curvas dos subgrupos. É sugerível que esses valores sejam produto de folhas em estado de transição quanto ao CRA, ou seja, sem controle estomático permitindo a dessecação dos tecidos. É possível propor que o motivo pelo qual essas folhas não foram detectadas como um estado fisiológico em P.hirsutissima se deva a velocidade com que os tecidos dessecam após a abertura dos estômatos, dificultando a coleta de indivíduos nesse estado, uma vez que pteridófitas TD dessecam em poucos dias (ALPERT, 2000).

Para o Fv/Fm a análise de mistura também indicou dois subgrupos distintos para P.hirsutissima e M.squamulosa, correspondendo aos estados fisiológicos de atividade metabólica e anabiose para P.hirsutissima e viabilidade e inviabilidade ou danos dos tecidos para M.squamulosa. Apesar da distribuição de P.hirsutissima não apresentar um formato bimodal, a probabilidade de ambos os subgrupos obtiveram valores altos o suficiente $(0,609$ e 0,390$)$ para indicar a existência de dois estados fisiológicos distintos. A distribuição estreita da primeira subpopulação sugere uma grande 
sensibilidade às condições do sistema fotossintético que permitem o uso da luz no vegetal, tornando uma pequena variação $(-0,5)$ suficiente para indicar a entrada no estado fisiológico da segunda subpopulação. Em M.squamulosa, a subpopulação correspondente ao estado de inviabilidade dos tecidos apresentou baixa probabilidade de ocorrência $(0,0635)$, indicando o estado senescente das plantas.

A análise de mistura de assimilação de carbono também indicou haver dois estados fisiológicos bem definidos (atividade metabólica e anabiose) em P.hirsutissima apresentou uma distribuição bimodal assim como a do CRA, porém com os subgrupos sobrepostos. Essa sobreposição pode indicar que mesmo sob o estado de atividade fotossintética, indivíduos de P.hirsutissima apresentam assimilação igual ou próxima a $0 \mu \mathrm{mol} \mathrm{m}^{-2} \mathrm{~s}^{-1}$, o que sugere algum fator de estresse ou dano foliar. M.squamulosa também apresentou dois subgrupos, sendo um deles novamente com baixa probabilidade de ocorrência $(0,0915)$, devido a provável senescência das folhas.

\subsubsection{Segregação de nichos}

De forma geral, as análises de misturas indicam a presença de dois estados fisiológicos naturais a P.hirsutissima (atividade metabólica e anabiose) e um estado em M.squamulosa (viabilidade). As diferenças entre os estados apresentados por ambas as espécies refletem suas estratégia e a forma delas de lidar com os fatores ambientais. Por apresentar o estado de anabiose, plantas TD, são pouco afetadas pela fotoinibição, porém para as plantas que mantém o metabolismo, como as plantas SD durante períodos de seca, a exposição à alta intensidade luminosa pode ser letal (HIETZ; BRIONES, 2001).

Apesar de P.hirsutissima e M.squamulosa apresentarem tendências de aumento dos valores de Fo durante o período seco, o fato de M.squamulosa apresentar um valor de Fo quase duas vezes maior que o de P.hirsutissima pode indicar que M.squamulosa apresenta uma maior suscetibilidade a danos induzidos pela luz. Apesar da estratégia TD, a priori, deixar os vegetais mais vulneráveis a luz, devido à impossibilidade de lidar com a energia de excitação durante a anabiose, é possível propor que essa estratégia leva a necessidade 
de mecanismos de proteção contra danos oxidativos mais eficientes do que de espécies SD.

Estudos comparativos entre TD e SD demonstram que espécies TD apresentam uma maior eficiência de proteção contra a luz do que espécies SD, apresentando ausência ou menores danos em consequência ao estresse oxidativo (HARTER; EICKMEIER, 1987; GEORGIEVA et al., 2007; FARRANT et al., 2009; BLOMSTEDT et al., 2010). Dessa forma, levando em conta que o estresse oxidativo é uma das maiores consequências deletérias da privação de água (DINAKAR et al., 2012), a hipótese inicial de que plantas TD ocupem posições no forófito com maior exposição luminosa que espécies SD é favorecida.

Segundo Scott (2000), mecanismos que protegem as plantas TD do estresse hídrico também são eficientes contra outros tipos de estresse, como a tolerância a ambientes salinos e de altas temperaturas, fazendo com que a capacidade de tolerar a dessecação permita que plantas TD habitem nichos inabitáveis para a maioria das outras espécies. O mesmo pode ocorrer com a intensidade luminosa. Essa hipótese também é sustentada pelos resultados obtidos através das análises de clorofila (razão da clorofila a/b), da curva de luz (P.C.L, R.Q.A) e do ensaio de suspensão da provisão hídrica.

As plantas tendem ajustar seu aparato fotossintético a luminosidade do ambiente de forma a aprimorar sua eficiência fotossintética. Uma vez que a razão da clorofila a/b pode ser relacionada positivamente com a proporção de pigmentos encontrado no complexo antena (chlorophyll-protein complex) do PSII e que a clorofila $b$ absorve de forma mais eficiente comprimentos de onda presente na luz difusa (comprimento de onda entre 400 e $500 \mathrm{~nm}$ ) (TERASHIMA; HIKOSAKA, 1995), a maior razão de clorofila a/b em $P$.hirsutissima indica a ocupação de suas folhas em regiões com maior intensidade luminosa do que M.squamulosa.

Da mesma forma, o ponto de compensação luminosa superior $e$ rendimento quântico aparente inferior em P.hirsutissima, indicam a aclimatação de suas folhas em regiões maior intensidade luminosa do que M.squamulosa. Por seus valores serem diretamente relacionadas com a capacidade 
fotoquímica da planta, esses resultados podem indicar que P.hirsutissima possui maior exigência quanto à radiação para fixar $\mathrm{Co}_{2}$ (LARCHER, 2003).

O ensaio realizado comparando folhas de M.squamulosa e $P$.hirsutissima expostas à luz e a sombra também reforça a hipótese de que P.hirsutissima seja apta a ocupar posições mais iluminadas. Grande parte das folhas e folhas sombreadas, de ambas as espécies, sobreviveram mesmo após um mês sem água, todavia das folhas expostas, somente as de P.hirsutissima conseguiram recuperar a capacidade de uso da luz enquanto todas as folhas de M.squamulosa entraram em senescência.

\subsubsection{Balanço de carbono}

Ao contrário do esperado, P.hirsutissima não apresentou um ganho de carbono superior a de M.squamulosa durante o período úmido, uma vez que não foi constatada diferença significativa entre seus valores médios. Durante o período seco, em que grande parte dos indivíduos de P.hirsutissima se encontra em anabiose, M.squamulosa apresentou maior assimilação de carbono, obtendo uma média mais elevada que P.hirsutissima. Logo, é possível afirmar que a viabilidade e manutenção da espécie TD P.hirsutissima no ambiente epifítico estudado, não é explicado por um maior ganho de carbono durante os períodos favoráveis.

Apesar do ganho de carbono não ser maior em P.hirsutissima, os resultados levam a crer que ela apresenta gastos acoplados a entrada de anabiose mesmo durante o período favorável, assim como o proposto inicialmente neste trabalho. A presença de valores baixos de CRA em P.hirsutissima durante o período úmido (mínimo de 50\%) indica que as folhas de P.hirsutissima foram submetidas a níveis severos de dessecação. Tomando como verdadeiro que os preparativos para o processo de anabiose têm início quando P.hirsutissima alcança valores de $60 \%$ de CRA, como foi discutido anteriormente, é possível sugerir que $P$. hirsutissima apresenta desvio de recursos do crescimento e reprodução dos indivíduos TD para preparar seus tecidos para a anabiose.

Apesar das folhas de P.hirsutissima apresentarem valores baixos de CRA durante o período úmido, a frequência de folhas com esse valor, 
observada na distribuição de CRA da análise de misturas, não foi alta. É possível sugerir que essa baixa frequência tenha ocorrido devido ao mecanismo de retardamento da perda de água presente em plantas TD indutivas.

As respostas apresentadas pela espécie TD, como o retardamento da perda de água, seguida da abertura dos estômatos para permitir a dessecação, faz com que plantas TD indutivas pareçam transitar entre a estratégia SD e TD do tipo constitutivo frente às condições do ambiente. $O$ retardamento da perda de água, além de permitir de forma temporal a preparação dos tecidos para a anabiose, permite um aumento no tempo de espera pela água enquanto os tecidos ainda estão aptos a retomarem a atividade fisiológica. Esse mecanismo auxilia a planta a evitar a entrada precoce em ciclos de dessecação e reidratação, aumentando o período de atividade fotossintética (AIDAR et al., 2010) e permitindo que as plantas desviem o investimento dos seus recursos do crescimento e reprodução, apenas quando são submetidas a condições de déficit hídrico (OLIVER, 1998).

É possível propor que o retardamento da perda de água possa auxiliar plantas TD indutivas na ocupação de ambientes com regimes de chuva com espaços curtos entre si. Além disso, a rápida recuperação fotossintética após a reidratação dos tecidos em TD é um fator importante para o balanço positivo de carbono, aumentando o tempo hábil para a fixação de carbono (EICKMEIER, 1979). Essa rápida recuperação se deve aos mecanismos eficientes de proteção e recuperação dos tecidos e à manutenção do sistema fotossintético durante o período dessecado (EICKMEIER, 1979; EICKMEIER, 1980), além do tipo de estratégia de proteção contra danos anti-oxidativos (homeoclorófila e peciloclorófila). A estratégia de homeoclorofilia em $P$. hirsutissima, evidenciada pela manutenção dos pigmentos fotossintéticos, favorece uma rápida recuperação após a reidratação.

\subsection{Considerações finais}

Ao contrário do esperado, P.hirsutissima não apresentou valores médios de ganho de carbono superiores a M.squamulosa nos períodos favoráveis. Apesar dos altos custos de TD, o ganho de carbono de P.hirsutissima e 
M.squamulosa foi igual no período úmido. Somando o período úmido ao seco M.squamulosa apresentou um ganho de carbono superior. Esses resultados levam a rejeição da hipótese de que os custos acoplados a estratégia TD, em P.hirsutissima, sejam compensados por um ganho de carbono superior a M.squamulosa. Esse fato vai ao encontro da teoria de demanda conflitante com produtividade.

Apesar de alocar grande parte dos recursos para a entrada da anabiose, P.hirsutissima não apresenta ganhos maiores de carbono e, portanto, é possível propor que sua alocação de recursos para o crescimento e a reprodução é limitada, podendo levar a uma desvantagem quanto a produtividade e a capacidade competitiva em comparação a M.squamulosa. Essa desvantagem poderia levar a exclusão de P.hirsutissima no ambiente epifítico, fato que não ocorre no ambiente estudado, levando a crer que a estratégia TD confere a P.hirsutissima outras vantagens relativas à M.squamulosa. Esses dados favorecem a proposta de Hietz e Briones (2001), de que a habilidade de evitar ou tolerar a dessecação e os mecanismos de proteção contra a fotoinibição são mais importantes na determinação da distribuição das espécies do que o desempenho da planta (assimilação de carbono, ponto de compensação luminosa e intensidade de luz em que a planta alcança $90 \%$ de sua fotossíntese máxima) (HIETZ; BRIONES, 2001).

Os resultados obtidos rejeitam o cenário inicial de que P.hirsutissima apresentaria ciclos constantes de dessecação e reidratação. Apesar dos valores de CRA alcançarem valores baixos, mesmo durante o período úmido (50\%), e o regime de chuvas apresentarem potencial para induzir oscilações constantes entre os estados de atividade fotossintética e estado de anabiose, a frequência com que esses valores baixos de CRA foram obtidos foi pequena. Esse fato pode sugerir que os mecanismos do tipo indutivo da TD, que retardam a perda de água, possibilitam um estado mais constante de atividade fotossintética, evitando maiores gastos e auxiliando na viabilidade de espécies TD indutivas em ambientes com períodos curtos entre as chuvas. Esse resultado vai contra a hipótese de balanço de carbono, entretanto somente os dados obtidos não são suficientes para rejeitá-la. 
Os resultados obtidos permitem propor que M.squamulosa possa sofrer maiores danos e/ou apresentar menor desempenho em microhabitats mais expostos a luz. Caso ocorresse, essa limitação fisiológica poderia diminuir o nicho fundamental de M.squamulosa ou diminuir seu desempenho em regiões mais iluminadas, abrindo espaço para a ocupação de P.hirsutissima e outras TD, cuja estratégia apresenta mecanismos mais eficientes de defesa contra a luz.

Os dados de clorofila e curva de luz ainda permitem levantar a hipótese de o nicho fundamental de P.hirsutissima seja limitado a regiões mais iluminadas. Ambientes sombreados poderiam levar indivíduos de P.hirsutissima a balanços de carbono negativos, sendo então excluídos de ambientes mais sombreados.

Os grupos apresentados pela análise de ordenação e as técnicas complementares de agrupamento são consistentes com a segregação de nichos. Ambos os grupos formados são constituídos por uma espécie de epífita SD acompanhada de outras epífitas TD. Esse fato poderia indicar que espécies SD apresentam efeito negativo uma sobre as outras, sendo possível propor que por apresentarem a mesma estratégia de uso da água ocupariam nichos iguais ou muito semelhantes, dificultando sua coexistência.

As espécies TD e as espécies que possuem a estratégia do metabolismo ácido das crassuláceas (CAM), (bromélias e cactáceas) também parecem se excluir. Sabendo que comumente espécies CAM se estabelecem em regiões mais expostas do forófito (LEVITT, 1980), essa observação reforça a hipótese de que espécies também TD ocupam essas regiões de maior exposição. Por outro lado, o fato de que todas as epífitas TD ocorrem em forófitos comuns a M.squamulosa também pode indicar uma interação positiva entre essas espécies.

Levando todas as observações em consideração, é possível propor um cenário em que durante os períodos de chuva M.squamulosa, apresente potencial para ocupar toda a superfície do forófito. Entretanto, durante o período de seca, as folhas presentes nas regiões mais expostas acabam sofrendo danos induzidos pela luz, abrindo espaço para o estabelecimento de espécies TD, como P.hirsutissima, que possuem mecanismos para se manter 
viáveis nessas condições. Nesse cenário é possível propor inclusive que os rizomas de M.squamulosa, que permanecem na superfície do forófito, mesmo após a senescência das folhas, possam facilitar o estabelecimento das espécies TD.

De acordo com os resultados obtidos no ensaio, mesmo após um mês sem irrigação e uma queda considerável do CRA, a maior parte as folhas de M.squamulosa mantidas na sombra se recuperaram. Em vista disso, é possível sugerir que períodos longos de seca ou a imprevisibilidade hídrica, como um fator isolado, não parece ser um fator restritivo ao estabelecimento de espécies. Entretanto, a falta de água impede que as plantas lidem de forma eficiente com outros fatores como altas temperaturas e alta intensidade luminosa, tornando a soma desses fatores altamente restritivos, necessitando de estratégias extremas para superá-las, como é o caso do desligamento total do metabolismo em TD.

A inativação total do metabolismo nos vegetais TD pode ser entendida como uma estratégia de alto custo, cujo principal objetivo é evitar a mortalidade dos tecidos vegetativos em condições restritivas de estresse hídrico. No entanto, devido aos altos custos da sua estratégia, é possível propor que o ambiente em que a TD seja vantajosa não seja apenas constituído pela imprevisibilidade hídrica, mas sim pela soma deste último a outros fatores restritivos, que juntos tornam as condições ambientais limitantes e impede o estabelecimento da maioria das espécies, como o que ocorre nos afloramentos rochosos. Essa suposta vantagem relativa em ambientes que a maioria das espécies não são capazes de habitar, poderia explicar o porquê de espécies TD serem raras apesar da maioria das espécies vegetais carregarem os genes necessários para expressar tal estratégia.

Logo, a estratégia TD tem como principal característica a inativação do metabolismo (envolvendo a dessecação completa dos tecidos), acoplado a mecanismos eficientes de proteção e recuperação, que permitem com que espécies evitem ao máximo a interação com os fatores ambientais de risco durante o período desfavorável, se tornado assim custoso, porém competente na evitação da mortalidade dos tecidos vegetativos. 


\section{Conclusão}

- A compensação da cessação da assimilação durante períodos de anabiose associada à estratégia de tolerância à dessecação em Pleopeltis hirsutissma, no ambiente epifíticos estudado, não é explicada por um ganho de carbono mais elevado do que aquele verificado em Microgramma squamulosa que não não apresenta tolerância à dessecação.

- Não foi rejeitada a hipótese de que a coexistência de Pleopeltis hirsutissma (TD) e Microgramma squamulosa (SD) seja facilitada pela segregação de nichos de intensidade luminosa. 


\section{REFERÊNCIAS}

AIDAR, S T; MEIRELLES, S, T; POCIUS, O; DELITTI, W, B, C; SOUZA, G, M; GONÇALVES, A, N. Desiccation tolerance in Pleurostima purpurea (Veloziaceae). Plant Growth Regulation, v. 62, p. 193-202, 2010.

ALPERT, P; OECHEL, W, C . Carbon Balance Limits the Microdistribution of Grimmia laevigata, a Desiccation-Tolerant. Plant. Ecology, v 66 : 660-669, 1985.

ALPERT, P. The discovery, scope, and puzzle of desiccation tolerance in plants. Plant Ecology, v.151, p.5-17, 2000.

ALPERT, P; OLIVER, M. Drying Without Dying. In: Black, M; Pritchard, H, W. Desiccation and Survival in Plants: Drying Without Dying. New York: CABI Publishing, Cap.1, p.3 - 43, 2002.

ALPERT, P. The limits and frontiers of desiccation-tolerant life, Integr. Comp.Biol. v 45, p. 685-695, 2005.

ALPERT, P. Constraints of tolerance: why are desiccation-tolerant organisms so small or so rare? J. Exp. Biol. V. 209, p. 1575-1584, 2006.

BAKER, N. R. Chlorophyll Fluorescence: A Probe of Photosynthesis In Vivo. Annu. Rev. Plant Biol, v. 59, p.89-113, 2008

BARRS, H.D. Determination of water deficits in plant tissue. In:KOZLOWSKI, T.T. (Ed) Water deficits and plant growth. New York, Academic Press, 1968. v.1, p.235-368. 
BEGON, M; TOWNSEND, C, R.; HARPER, J, L. Ecology: From Individuals to Ecosystems. 4. ed.: Blackwell Publishing Ltd, 2006, 759 p.

BEWLEY, J D. Physiological aspects of desiccation tolerance. Annual Review of Plant Physiology, v 30, p. 195-238, 1979.

BIEHLER K, FOCK H P. Evidence for the contribution of the Mehler-peroxidase reaction in dissipation of excess electrons in drought-stressed wheat. Plant Physiology, v 112, p. 265-72, 1996.

BJORKMAN O; DEMMING B. Photon yield of $\mathrm{O} 2$ evolution and chlorophyll fluorescence at $77 \mathrm{k}$ among vascular plants of diverse origins. Planta. v 170, p. 489-504, 1987.

BLOMSTEDT, C, K; CARA, A, G; FREDERICKS, D, P; HAMILL, J, D; GAFF, D, F; NEALE, A, D. The resurrection plant Sporobolus stapfianus: An unlikely model for engennering enhanced plant biomass?.Plant Growth Regulation. 62: 217-232, 2010.

BOLHAR-NORDENKAMPF, H. R; LONG, S. P.; BAKER N. R.; OQUIST, G.; SCHREIBER,U. LECHNER, G. Chlorophyll Fluorescence as a Probe of the Photosynthetic Competence of Leaves in the Field: A Review of Current Instrumentation. Functional Ecology, v 3, n. 4, p. 497-514, 1989.

BRAUN-BLANQUET, J. 1928-1964. Fitosociologia; bases para el estudio de las comunidades vegetales. Trad. da 3.ed.rev.aum. Blume, Madrid, p. 820 , 1979 
CAEMMERER, S.; FARQUHAR, G.D.Some relationships between the biochemistry of photosynthesis and the gas exchange of leaves. Planta, Berlin, v.153, p.376-387, 1981.

CASPER, C; EICKMEIER, W, G; OSMOND, C,B. Changes of fluorescence and xanthophyl pigments during dehydration in the resurrection plant Selaginella lepidophylla in low and medium light intensities. Oecologia, v.94, p.528-533, 1993.

COLVILLE, L; KRANNER, I. Desiccation tolerant plants as model systems to study redox regulation of protein thiols. Plant Growth Regulation, v.62, p. 241-255, 2010.

CORNIC, G; GHASHGHAIE, J; GENTY, B; BRIANTAIS, J,M. Leaf photosynthesis is resistant to a mild drought stress. Photosynthetica, v.27, n.3, p. 295-309, 1992.

CORNWELL, W. K.; SCHWILK, D. W.; ACKERLY, D.D. A Trait-based test for habitat filtering: convex hull volume. Ecology, v 87, p.1465-1471, 2006.

CRAINE, J, M. Reconciling plant strategy theories of Grime and Tilman. Journal of Ecology, v.93, p.1041-1052, 2005.

CROWE, J H; HOESKSTRA, F, A; CROWE, L, M, Anhydrobiosis. Rev. Physiol, v 54, p. 579- 99, 1992.

DEMMIG, B; BJÖRKMAN, O. Comparison of the effect of excessive light on chlorophyll fluorescence (77K) and photon yield of $\mathrm{O} 2$ evolution in leaves of higher plants. Planta, v.171, n.2, p.171-184, 1987. 
DÍAZ, S; CABIDO, M. Vive la différence: plant functional diversity matters to ecosystem processes. Trends in Ecology \& Evolution, v.16, n.11, p. 646-655, 2001.

DINAKAR, C; DJILIANOV, D; BARTELS, D. Photosynthesis in desiccation tolerant plants: Energy metabolism and antioxidative stress defense. Plant Science, v. 182, p.29- 41, 2012

DISLICH, R. Florística e estrutura do componente epifítico vascular na mata da reserva da Cidade Universitária "Armando de Salles Oliveira", São Paulo, SP. 1996. Dissertação (Mestrado em Ecologia: Ecossistemas Terrestres e Aquáticos) - Instituto de Biociências, Universidade de São Paulo, São Paulo, 1996. Disponível em: <http://www.teses.usp.br/teses/disponiveis/41/41134/tde-26052002-183059/>. Acesso em: 2012-09-06.

DISLICH, R; MANTOVANI, W. A flora de epífitas da reserva da Cidade Universitária "Armando de Salles Oliveira" (São Paulo, Brasil). Boletim Botânico da Universidade de São Paulo 17: 61-84, 1998.

EICKMEIER, W G. Photosynthetic recovery in the resurrection plant Selaginella lepidophylla after wetting. Oecologia, Berlin, v 39, p. 93-10, 1979.

EICKMEIER, W, G, Photosynthetic recovery of resurrection spikemosses from different hydration regimes. Oecologia, v.46, p.380-385, 1980.

EICKMEIER W G. Photosynthetic recovery of the resurrection plant Selaginella lepidophylla (Hook. And Grev.) Spring: effects of prior desiccation rate and mechanisms of desiccation damage. Oecologia, v 58, p. 115-120, 1983.

FARRANT J M, COOPER K, KRUGER L A, SHERWIN H W. The effect of drying rate of the survival of three desiccation-tolerant angiosperm species. Annals of Botany, v.84, p, 371-379, 1999. 
FARRANT, J, M. A comparison of mechanisms of desiccation tolerance among three angiosperm resurrection plant species. Plant Ecology, v.151, p. 29-39, 2000.

FARRANT, J, M; LEHNER, A; COOPER, K ; WISWEDEL, S. Desiccation tolerance in the vegetative tissues of the fern Mohria caffrorum is seasonally regulated. The Plant Journal, v 57, p.65-79, 2009.

FERNÁNDEZ-MARÍN, B; MÍGUEZ, F.; BECERRIL, J, M.; GARCÍA-PLAZAOLA, J. I . Dehydration-mediated activation of the xantophyll cycle in darknees: is it related to desiccation tolerance?. Planta, v. 234, p. 579-588, 2011.

GAFF, D, F. Desiccation-tolerant flowering plants in Southern Africa. Science, v 174, p.1033-1034, 1971.

GAFF D. F. Desiccation Tolerant Vascular Plants of Southern Africa. Oecologia (Berl.) v.31, p.95-109, 1997.

GARAY-ARROYO, A; COLMENERO-FLORES, J, M; GARCIARRUBIO, A; COVARRUBIAS, A, A. Highly hydrophilic proteins in prokaryotes and eukaryotes are common during conditions of water deficit. J Biol Chem, v.275, p.5668-5674, 2000.

GENTY, B; BRIANTAIS, J,M; BAKER, N, R. The relationship between the quantum yield of photosynthetic electron transport and quenching of chlorophyll fluorescence. Biochimica et Biophysica Acta, v.990,p. 87-92, 1989.

GEORGIEVA K, SZIGETI Z, SARVARI E, GASPAR L, MASLENKOVA L, PEEVA V, PELI E,TUBA Z. Photosynthetic activity of homoiochlorophyllous desiccation tolerant plant Haberlea rhodopensis during dehydration and rehydration. Planta, v 225, p. 955-964, 2007. 
GODDE, D. Adaptations of the photosynthetic apparatus to stress conditions. In Plant Responses to Environmental Stresses (ed. H.R. Lerner), p. 449-474. Marcel Dekker, New York, 1999.

GRIME, J,P. Trait convergence and trait divergence in herbaceous plant communities: mechanisms and consequences. Journal of Vegetation Science, v.17, p.255-260, 2006.

HARTER, J, B; EICKMEIER, W, G. Comparative desiccation tolerance of three desert pteridophytes: Response to long-term desiccation. American Midland Naturalis, v.18, n.2, p.337-347, 1987.

HIETZ, P; BRIONES, O. Photosynthesis, Chlorophyll Fluorescence and WithinCanopy Distribution of Epiphytic Ferns in a Mexican Cloud Forest. Plant Biology, v.3, p.279-287, 2001

HOEKSTRA, F, A; GOLOVINA, E, A; BUITINK, J. Mechanisms of plant desiccation tolerance. Trends in Plant Science, v.6, p. 431-438, 2001

ILJIN, W, S. Drought resistance in plants and physiological processes. Annu Rev Plant Physiol. v 3, p. 341-363, 1957.

INGLE, R, A; SCHMIDT, U, G; FARRANT, J, M; THOMSON, J, A; MUNDREE, $S, G$. Proteomic analysis of leaf proteins during dehydration of the resurrection plant Xerophyta viscosa. Plant Cell Environ. v 30, p. 435-446, 2007.

ILLING, N; DENBY K; COLLETT, H; SHEN, A; FARRANT, J, M. The signature of seeds in resurrection plants: a molecular and physiological comparison of desiccation tolerance in seeds and vegetative tissues.Integ. Comp. Biol. v 45, p.771-787, 2005.

INGRAM, J; BARTELS, D. The molecular basis of dehydration tolerance in plants. Annual Review of Plant Physiology and Plant Molecular Biology, v.47, p.377-403, 1996. 
JAMIESON, D, J. Oxidative stress response of the yeast Saccharomyces cerevisiae. Yeast, v 14, p. 1511-1527, 1998.

JONES, H. G. Plants and microclimate: A quantitative approch to environmental plant physiology. 2.ed: Cambridge University Press, p. 384, 1992

KAISER, W, M. Effects of water defcit on photosynthetic capacity. Physiol. Plantarum, v 71, 142 - 149, 1987

KEDDY, P.A. Assembly and response rules: two goals for predictive community ecology. Journal of vegetation Science, v 3, 157-164, 1992.

KLUGE, M; AVADHANI, P, N; GOH, C, J. Gás exchange and water relations in epiphytic tropical ferns. In: LUTTGE, U (Ed.). Vascular Plants as Epiphytes: Evolution and Ecophysiology: Springer-verlag, cap.4, p.87-108, . 270 p, 1989.

KNEITEL, J,M; CHASE, J, M. Trade-offs in community ecology: linking spatial scales and species coexistence. Ecology Letters. v 7,p. 69-80, 2004.

KRAMER, P. J. \& BOYER, J. S.. Water relations of plants and soils. Academic Press, New York., 1995

KRAUSE, G, H; WEIS, E. Chlorophyll fluorescence as a tool in plant physiology. II. Interpretation of fluorescence signals. Photosynthesis Research, v.5, p.139-157, 1984.

KREBS, C. J. Ecology: The experimental analysis of distribution and abundance. $4^{\mathrm{a}}$ ed. Harper \& Collins, New York, p.680, 1994 
LABIAK, P.H., HIRAI, R.Y. 2010. Polypodiaceae in Lista de Espécies da Flora do Brasil. Jardim Botânico do Rio de Janeiro. (http://floradobrasil.jbrj.gov.br).

LAMBERS, H; III, CHAPIN III, F, S, T; ; PONS, T,S. Plant Physiological Ecology. 2. ed.: Springer, 2008.

LANGE, O, L; MEYER, A; ZELLNER, H; HEBER, U. Photosynthesis and water relations of lichen soil crusts: field measurements in the coastal fog zone of the Namib Desert. Functional Ecology, v 8, p. 253-264, 1994.

LARCHER, W. Physiological Plant Ecology. 4. ed: Ed. Springer-Verlag, Berlin, 2003

LEBKUECHER G J, EICKMEIER G W . Physiological benefits of stem curling for resurrection plants in the field. Ecology, v. 74, n.4, p. $1073-1080,1993$.

LEGENDRE, P; LEGENDRE. Numerical Ecology. 2ed. English edn Elsevier, Amsterdam, 1998.

LEPRINCE O, BUITINK J. Desiccation tolerance: From genomics to the field. Plant Science 179: 554 - 564, p. 2010.

LEVITT, J. Responses of plants to environmental stresses. New York, Academic Press 2, cap.15, 1980.

LUTTGE, U. Physiological ecology of tropical plants.: Springer-verlag, 384 p, 1997.

MEDRANO H, ESCALONA J M, BOTA J, GULÍAS J, FLEXAS, J. Regulation od photosynthesis of C3 plants in response to progressive Drought: stomatal conductance as a reference parameter. Annals of Botany. v 89, p. 895-905, 2002. 
MEGURO M; JOLY C, A; BITTENCOURT, M,M. Stress hídrico e alguns aspectos do comportamento fisiológico em Xerophyta plicata Spreng.Velloziaceae. Bol Bot Univ São Paulo. v 5, p. 27-42, 1977.

MEIRELLES, S. T. ; SILVA, A.C. DA ; MATTOS, E.A. . Potential desiccation tolerant vascular plants from southeastern Brazil.. Polish Journal of Environmental Studies, Polônia, v. 6, p. 17-21, 1997.

MITTLER R. Oxidative Stress, antioxidants and stress tolerance. Trends Plant Sci.,v 7, p. 405-410, 2002.

MOORE, J.P, WESTALL K L, RAVENSCROFT N, FARRANT J M, LINDSEY G $G$, BRANDT W $F$. The predominant polyphenol in the leaves of the resurrection plant Myrothamnus flabellifolius,3,4,5-tri-O -galloylquinic acid, protects membranes against desiccation and free radical-induced oxidation. Biochem. J., v.385, 301-308, 2005.

MOORE, J, P; HEARSHAW, M; RAVENSCROFT, N; LINDSEY, G, G; FARRANT, J, M; BRANDT, W, F. Desiccation-induced ultrastructural and biochemical changes in the leaves of the resurrection plant Myrothamnus flabellifolia. Aust. J. Bot., v.55, p.482-491, 2007.

NEALE, A, D; BLOMSTEDT, C, K; BRONSON, P, LE, T-N; GUTHRIDGE, K, EVANS, J; GAFF, D, F; HAMILL, J, D. The isolation of genes from the resurrection grass Sporobolus stapfianus which are induced during severe dought stress. Plant, Cell and Environment. v, 23, p. 265-277, 2000.

OLIVER, M, J. Desiccation tolerance in vegetative plant cells. Physiologia Plantarum. V. 97, p. 779-787, 1996. 
OLIVER, M J, BEWLEY, J D. Desiccation-tolerance of plant tissues: a mechanistic overview. Horticulture Review. v 18, p. 171-213, 1997.

OLIVER, M, J; WOOD, A, J; O'MAHONY, P. "To dryness and beyond"preparation for the dried state and rehydration in vegetative desiccation-tolerant plants. Journal of Plant Growth Regulation, v 24, p.193-201, 1998.

OLIVER, M J; TUBA, Z; MISHLER, B, D. The evolution of vegetative desiccation tolerance in land plants, Plant Ecolpgy. V.15, p. 85-100, 2000.

OLIVER, M, J; VELTEN J; MISHLER B, D. Desiccation Tolerance in Bryophytes: A Reflection of the Primitive Strategy for Plant Survival in Dehydrating Habitats?. Integr. Comp.Biol., 45:788-799, 2005.

PETERS, S.; MUNDREE, S, G; THOMSON, J,A; FARRANT, J,M; KELLER, F. Protection mechanisms in the resurrection plant Xerophyta viscosa (Baker): both sucrose and raffinose family poligosaccharides (RFOs) accumulate in leaves in response to water deficit. J. Exp. Bot, v.58, p.1947-1956, 2007

POREMBSKI, S; BARTHLOTT, W. Granitic and gneissic outcrops (inselbergs) as centers of diversity for desiccation-tolerant vascular plants. Plant Ecology. v15, p. 19-28, 2000.

PRITEO-DAPENA P, CASTAÑO R, ALMOGUERA C, JORDANO J. The ectopic overexpression of a seeds pecific transcription factor, HaHSFA9, confers tolerance to severe. The Plant Journal, v.54, p.1004-1014, 2008.

RESING, S, A et al. The physcomitrella genome reveals evolutionary insights into the Conquest of Land by Plants.Science. v. 319, p. 64-69, 2008. 
ROTHSCHILD, L, J, MANCINELLI, R, L. Life in extreme environments. Nature v, 409, p. $1092-1101,2001$.

SCHMEING, A. CAMPOS, V. M.; BARBOSA, J. M., MEIRELLES, S. T. Comportamento higroscópico e tolerância à dessecação em Polypodium hirsutissimum Raddi. VIII Congresso de ecologia do Brasil, 2007

SCHREIBER U. Detection of rapid induction kinetcs with a new type of highfrequency modulated chlorophyll fluorescence quenching with a new type of modulatioin fluorometer. Photosynth Res., v 9, p. 261-272, 1986.

SCHREIBER, U.; BILGER, W.; NEUBAUER, C. Chlorophyll fluorescence as a non-intrusive indicator for rapid assessment of in vivo photosynthesis. In: SCHULZE, E.D.; CALDWELL, M.M. (Ed.).Ecophysiology of photosynthesis. Berlin: Springer,. p.49-70, 1994.

SCOTT, P. Resurrection Plants and the Secrets of Eternal Leaf. Annals of Botany, v.85, p.159-166, 2000.

SHERWIN H W, FARRANT J M. Differences in rehydration of three desiccationtolerant angiosperm species, Annals of botany, v.78, p.703-710, 1996.

SHERWIN, H, W; FARRANT, J, M. Protection mechanisms against excess light in the resurrection plants Craterostigma wilmsii and Xerophyta viscosa. Plant Growth Regulation, v. 24, p. 203-210, 1998.

SILVERTOWN, J. Plant coexistence and the niche. Trends in Ecology \& Evolution, v 19, p. 605-611, 2004.

SMITH, A. R.; PRYER, K. M.; SCHUETTPELZ, E.; KORALL, P.; SCHNEIDER, H. \& WOLF, P. G. A classification for extant ferns. Taxon, v.55, p.705-731, 2006.

TERASHIMA, I; HIKOSAKA, K. Comparative ecophysiology of leaf and canopy photosynthesis. Plant, Cell \& Environment, v.18, p.1111-1128, 1995. 
TOLDI, O; TUBA, Z; SCOOT, P. Vegetative desiccation tolerance: Is it a goldmine for bioengineering crops ? Plant Science, V. 176, p. 187-199, 2009.

TUBA, Z; LICHTENTHALER H, K; CSINTALAN, Z; NAGY, Z; SZENTE, K. Loss of chlorophylls, cessation of photosynthetic $\mathrm{CO} 2$ assimilation and respiration in the poikilochlorophyllous plant Xerophyta scabrida during desiccation, Physiol. Plant. 96: 383-388, 1996.

TUBA, Z; PROCTOR, M, C, F; CSINTALAN, Z. Ecophysiological responses of homoiochlorophyllous and poikilochlorophyllous desiccation tolerant plants: a comparison and an ecological perspective. Plant Growth Reg. v 24, p. $211-$ 217, 1998.

TUBA, Z. Notes on the poikilochlorophyllous desiccation-tolerant plants. Acta Biologica Szegediensis,v. 52, n.1, p.111-113, 2008

VENN, S, E; GREEN, K, PICKERING, M; MORGAN, J, W. Using plants functional traits to explain community composition across a strong environmental filter in Autralian alpine snowpatches. Plant Ecology, v. 212, p. 1419-1499, 2011

WATKINS J. E., JR., KAWAHARA A.Y., LEICHT S. A., AULD J. R., BICKSLER A. J., KAISER K. Fern laminar scales protect against photoinhibition from excess light. American Fern Journal, v 96, p. 83-92, 2006.

WEIHER, E.; KEDDY, P. Assembly rules, null models, and trait dispersion: new question from old patterns. Oikos, v 74, n 1, p. 159-164, 1995.

WELLBURN A. R. The spectral determination of chlorophylls and $a$ and $b$, as well as total carotenoiids, using various solvents with spectophotometers of different resolution. J. Plant. Physiol., v144, p. 307-313, 1994. 
WHITTAKER, A; BOCHICCHIO, A; VAZZANA, C; LINDSEY, G; FARRANT, J, $M$. Changes in leaf hexokinase activity and metabolite levels in response to drying in the desiccation-tolerant species Sporobolus stapfianus and Xerophyta viscosa. Journal of Experimental Botany, v. 52, p. 961-969, 2001.

WILLIGEN, C. V.; PAMMENTER, N.W.; MUNDREE, S; FARRANT, J. Some physiological comparisons between the resurrection grass, Eragrostis nindensis, and the related desiccation-sensitive species, E. curvula. Plant Growth Reg. v 35, p. 121-129, 2001.

WISE, M, J; TUNNACLIFFE, A. POPP the question: what do LEA proteins do? Trends Plant Sci. v.9, p. 747-757, 2004.

ZOTZ, G; HIETZ, P. The physiological ecology of vascular epiphytes: current knowledge, open questions. Journal of Experimental Botany,v.52, n.364, p.2067-2078, 2001. 


\section{GLOSSÁRIO}

Eficiência do uso da água (EUA) - A eficiência do uso da água é definida agronomicamente como a razão da massa seca produzida pela massa de água utilizada. Uma vez que as plantas apresentam fixação de $\mathrm{Co}_{2}$ e que os átomos de carbono e de oxigênio contribuem com a maior parte da massa seca da planta, é possível representa-la pela atividade fotossintética. Dessa forma a eficiência das trocas gasosas pode ser definida como a razão de $\mathrm{Co}_{2}$ adquirida pela massa de água transpirada (KRAMER; BOYER, 1995).

Fo e Fs - Fluorescência basal em estado adaptados ao escuro (Fo) e em estado adaptado a luz (Fs). A fluorescência basal (Fo) representa a emissão de fluorescência quando os centros de reação do PSII estão abertos e o aceptor primário, quinona a (Qa), é oxidado (BOLHAR-NORDENKAMPF, et al 1989).

Fm e Fm' - Fluorescência máxima em estado adaptado ao escuro $(F m)$ e em estado adaptado a luz $\left(\mathrm{Fm}^{\prime}\right)$. A fluorescência máxima $(\mathrm{Fm})$ representa a emissão da fluorescência em seu valor máximo e em que todos centros de reação estão fechados. Nesse momento os elétrons começam a deixar $\mathrm{Qa}$, levando ao aumento fotoquímico e a queda da fluorescência (BOLHARNORDENKAMPF, et al 1989).

Fv e Fv'- Fluorescência variável em estado adaptado ao escuro ( $F v)$ e em estado adaptado a luz $\left(\mathrm{Fv}^{\prime}\right)$. Representa a diferença entre a fluorescência máxima (toda Qa reduzida) e a fluorescência basal (toda Qa oxidada). Demonstrates the ability of PSII to perform photochemistry (QA reduction) (BAKER, 2008).

Fv/Fm - Rendimento quântico máximo do PSII (Fv/Fm) representa a eficiência máxima na qual a luz que é absorvida pelo PSII e usada para reduzir Qa (BAKER, 2008). 
Fv'/Fm'- O rendimento quântico efetivo do PSII fornece uma estimativa da eficiência máxima do PSII fotoquímico a uma dada densidade de fluxo de fótons fotossinteticamente ativa (DFFF), que corresponde a eficiência operacional de PSIl se todos os centros de reação do PSIl estiverem oxidados (abertos) (BOLHAR-NORDENKAMPF, et al 1989; BAKER, 2008). 